\title{
Review: Circulation of Inorganic Elements in Combustion of Alternative Fuels in Cement Plants
}

Cortada Mut, Maria del Mar; Nørskov, Linda Kaare; Jappe Frandsen, Flemming; Glarborg, Peter; DamJohansen, Kim

\section{Published in:}

Energy and Fuels

Link to article, DOI:

10.1021/ef502633u

Publication date:

2015

Document Version

Peer reviewed version

Link back to DTU Orbit

Citation (APA):

Cortada Mut, M. D. M., Nørskov, L. K., Jappe Frandsen, F., Glarborg, P., \& Dam-Johansen, K. (2015). Review: Circulation of Inorganic Elements in Combustion of Alternative Fuels in Cement Plants. Energy and Fuels, 29(7), 4076-4099. https://doi.org/10.1021/ef502633u

\section{General rights}

Copyright and moral rights for the publications made accessible in the public portal are retained by the authors and/or other copyright owners and it is a condition of accessing publications that users recognise and abide by the legal requirements associated with these rights.

- Users may download and print one copy of any publication from the public portal for the purpose of private study or research.

- You may not further distribute the material or use it for any profit-making activity or commercial gain

- You may freely distribute the URL identifying the publication in the public portal 


\title{
Review: Circulation of inorganic elements in
}

\section{combustion of alternative fuels in cement plants}

\author{
Maria del Mar Cortada Mut ${ }^{*}$, Linda Kaare Nørskov ${ }^{2}$, Flemming Jappe Frandsen ${ }^{1}$, Peter \\ Glarborg $^{1}$, and Kim Dam-Johansen ${ }^{1}$ \\ ${ }^{1}$ Department of Chemical and Biochemical Engineering, CHEC Research Centre, Technical \\ University of Denmark (DTU), DK-2800 Lyngby, Denmark. \\ ${ }^{2}$ FLSmidth A/S, Vigerslev Allé 77, DK-2500 Valby, Denmark
}

* Søltofts Plads Building 229, DK-2800 Kgs. Lyngby,

Author email address: mmarc@kt.dtu.dk. Telephone: +45 45252920

KEYWORDS: sulfur, chlorine, alkalis, volatile elements, combustion, alternative fuels, cement, circulation, build-ups 


\section{ABSTRACT}

Cement production is an energy-intensive process, which traditionally has been dependent on fossil fuels. However, the use of alternative fuels, i.e., selected waste, biomass and by-products with recoverable calorific value, is constantly increasing. Combustion of these fuels is more challenging compared to fossil fuels, due to lack of experience and different chemical and physical properties. When complete oxidation of fuels in the calciner and main burner is not achieved, they burn in direct contact with the bed material of the rotary kiln, causing local reducing conditions and increasing the internal circulation of $\mathrm{S}, \mathrm{Cl}, \mathrm{Na}$, and $\mathrm{K}$. Compounds containing these elements, such as alkali salts, evaporate when exposed to high temperatures and subsequently condense in colder parts of the plant. The transformation of the volatile inorganic species at different locations in the cement plant is important, because a high internal circulation affects the process stability and operation through formation of build-ups and blockages, ring formation, and shell corrosion, resulting in reduced clinker production, higher heat consumption, and kiln or plant stops. The present review describes the internal cycles of inorganic elements that are established within the cement plant and their dependence on process parameters. Special focus is given to the sulfur cycle. This cycle is intensified by $\mathrm{CaSO}_{4}$ decomposition, making it sensitive to local reducing conditions. 


\begin{tabular}{|llll|}
\hline Nomenclature /Abreviations & & \\
LSF & Lime saturation factor [\%] & $\mathrm{T}$ & Temperature [ $\left.{ }^{\circ} \mathrm{C}\right]$ \\
$\mathrm{M}_{i}$ & Molar mass [g/mol] & VLS & Vapor-liquid-solid [-] \\
$\mathrm{MBM}$ & Meat and Bone meal & $\mathrm{VM}$ & Volatile Matter [wt.\%] \\
$\mathrm{MSW}$ & Municipal solid waste & $\mathrm{w}_{i}$ & Concentration [wt.\%] \\
$\mathrm{FC}$ & Fixed Carbon [wt.-\%] & $\mathrm{A}$ & Empirical fraction [-] \\
$\mathrm{P}_{i}$ & Partial pressure [atm] & E & Evaporation factor [-] \\
PE & Polyethylene & Subscripts & \\
PVC & Poly-Vinyl-Chloride & LOI free & Loss of ignition free \\
RDF & Refused derived fuel & equiv & Equivalent \\
TDF & Tired derived fuel & B & Bed \\
\hline
\end{tabular}

\section{Introduction}

Cement has been known as a binder material since ancient times, and it is a key material in the building and construction industry. The annual global cement production has been growing steadily, from 100 million tons in $1950^{1}$ to 2600 million tons in $2006^{2}$. After the global economic down of 2007-2009, the cement production has recovered, and in 2013 a total of four billion tons cement was estimated to be manufactured worldwide ${ }^{3}$.

Cement production is an energy-intensive process, which requires approximate $3 \mathrm{MJ}$ per $\mathrm{kg}$ cement clinker produced, equivalent to $60-130 \mathrm{~kg}$ coal/ton of cement clinker $^{4}$. The energy consumed by the cement industry is estimated to constitute about $2 \%$ of the global primary energy consumption ${ }^{5}$. The fuel consumption accounts for $30-40 \%$ of the total cement production costs. The cement industry has mainly been dependent on the usage of fossil fuels, such coal, 
petcoke, oil, and natural gas. During the last decades, an interest in replacing fossil fuels with selected waste, biomass and by-products with recoverable calorific value, defined as alternative fuels, has arisen, in order to minimize production cost, reduce environmental impact, and reduce fuel costs ${ }^{6-9}$.

The utilization of alternative fuels imposes challenges on the calciner and kiln operation because these fuels have different combustion characteristics compared to fossil fuels. A particular concern is incomplete combustion of the fuels, since this may alter the behavior of minor elements such as $\mathrm{S}, \mathrm{Cl}, \mathrm{Na}$ and $\mathrm{K}$. These elements are known to be circulating or volatile elements in the kiln system. Compounds containing these elements evaporate when exposed to high temperatures, and may subsequently condense in cooler parts of the plant. They often cause difficulties in kiln operation due to material build-up, ring formation, and, on a longer time-scale, shell corrosion. These phenomena reduce the kiln performance and cause higher heat consumption, and frequently kiln or plant operational stops. The energy penalty caused by the circulation phenomenon is believed to be significant but presently no reliable estimates are available. Incomplete combustion of fuels in the calciner and/or kiln burner may lead to an increase in the Cl- and especially S-circulation in cement plants. This unwanted phenomenon is more pronounced for alternative fuels than for fossil fuels. While solid fossil fuels are typically pulverized before use, alternative fuels are often introduced to the kiln system in the form of large millimeter or centimeter sized particles that are more difficult to combust.

In this review, the circulation of $\mathrm{S}, \mathrm{Cl}, \mathrm{Na}$, and $\mathrm{K}$, and the transformation of different species of these elements at different locations in the cement plant, as well as the dependence on fuel and process parameters, is discussed, since a high internal circulation seriously affect the process stability and operation. 


\subsection{Overview of the pyro process in cement plants}

Portland cement is manufactured from Portland cement clinker, and its production accounts for around $80 \%$ of the energy used in cement manufacturing ${ }^{10}$. The main constituents of the raw materials required for cement production are $\mathrm{CaO}, \mathrm{SiO}_{2}, \mathrm{Al}_{2} \mathrm{O}_{3}$ and $\mathrm{Fe}_{2} \mathrm{O}_{3}$, which are provided typically by a mixture of ground limestone, clay, sand, shale, marl, bauxite, and iron ore ${ }^{11,12}$. Portland clinker consists mainly of belite, alite, ferrite, and aluminate, comprising more than 90 wt. $\%$ of the product. The clinker phase formation and reactions have been summarized in several books ${ }^{11-13}$, and review papers ${ }^{14-16}$.

The cement production process can be divided into three consecutive parts: ${ }^{1)}$ Preparation of the raw materials, ${ }^{2)}$ pyro-processing, and ${ }^{3)}$ clinker processing. The pyro-processing step is the heart of cement production and covers the thermal treatment of the raw material, necessary to obtain the cement clinker. It involves the preheating of raw materials, calcination, clinker reactions, and cooling of the clinker. These steps take place in the kiln system, which consists of a preheater tower, a calciner, a rotary kiln, and a clinker cooler. A typical modern kiln system is schematically illustrated in Figure 1.

The raw materials, referred to as raw meal in the kiln system, are introduced to the preheater tower. This tower consists of a series of 4-6 vertical cyclones, arranged in a 50-120 m high tower structure. The raw meal is heated by direct contact with hot exhaust gases from the kiln, flowing counter-currently. Thus, a part of the thermal energy is recovered in the system. The most common preheater tower is the five staged, which involves five cyclones. 
The preheated raw meal is admitted to the calciner, where the majority of $\mathrm{CaCO}_{3}$ will decompose thermally into $\mathrm{CaO}$ and $\mathrm{CO}_{2}$. Hot air from the clinker cooler, so-called tertiary air, is utilized as combustion air in the calciner. The consumption of fuel for calcination can account for up to $60 \%$ of the fuel heat input needed for cement production ${ }^{18}$. The calciner can be integrated into the kiln system as In-Line Calciner (ILC), where the flue gas from the rotary kiln passes through the calciner, or as Separate-Line Calciner (SLC), where the flue gas from the rotary kiln bypasses the calciner, and enters the preheater. The ILC-system is preferred because it minimizes the amount of gas flowing through the rotary kiln, allowing for a rotary kiln size reduction. In addition, good conditions for reduction of $\mathrm{NO}_{\mathrm{x}}$ produced in the rotary kiln are achieved $^{19}$. On the other hand, in a SLC-configuration, fuel combustion takes place more rapidly, due to a higher $\mathrm{O}_{2}$ concentration, and a smaller calciner volume is needed compared to the ILCsystem for a fixed residence time, since the amount of gas through the calciner is smaller ${ }^{19}$. However, the solids residence time is lower in a SLC system and the mass and the particle behaviours reduce the heat transfer from gas to fuel particle ${ }^{20}$. This article will refer only to the ILC-configuration because it is the preferred and most common design nowadays.

The hot meal, i.e. calcined raw meal after the $5^{\text {th }}$ stage cyclone, enters the rotary kiln and flows counter-currently to the hot flue gases that are produced by the kiln burner flame. The rotary kiln can be divided into three different zones, as specified in

Figure 1. The material cold end is the inlet of hot meal into the rotary kiln. In the transition zone, the materials start to melt and form the clinker nodules. The clinker reactions take place in the burning zone, or the hot end of the rotary kiln, where the clinker achieves a temperature of up to $1450^{\circ} \mathrm{C}^{11-13,19}$. 
The clinker is cooled by atmospheric air in the clinker cooler, which is typically a grate cooler $^{11,21}$. In this manner, preheated combustion air is produced and returned to the process through the rotary kiln (for combustion of the main burner fuel as secondary air) and the calciner (for combustion of the calciner fuel, as tertiary air). Grate coolers provide the most efficient and most flexible heat recovery system for modern cement plants ${ }^{22}$. Experience has shown that a rapid cooling from 1450 to $1200^{\circ} \mathrm{C}$ is advantageous in order to minimize the formation of secondary belite and free lime $\mathrm{e}^{11,13}$.

In modern cement plants, a bypass system for the process gases can be installed in order to reduce the chloride concentration the kiln. The bypass system involves extracting a portion of kiln exhaust gases, cooling the extracted exhaust gases, and separating the dust. The bypass starts at the gas extraction point, which is located at the kiln side of the riser duct. At this position, the kiln gases have a low dust concentration and high gaseous concentration of $\mathrm{Cl}^{23}$. The extracted kiln gases containing $\mathrm{Cl}$ and kiln dust are quenched by air, in order to initiate condensation of the chlorides and facilitate the subsequent separation of chlorides from the gas. This separation takes place in an electrostatic precipitator or a baghouse filter ${ }^{23}$. Typical bypass rates are of up to $15 \%$ for chlorine $\mathrm{e}^{24}$. The installation of the bypass requires additional capital investment and increases heat and material losses. The removal of hot gas by the bypass leads to higher specific heat consumption of about 6-12 MJ/ton clinker per percent of removed kiln inlet gas ${ }^{24}$.

An overview of the temperature and residence times for both the gas and solids, and the $\mathrm{O}_{2}$ concentration in the gas phase, for a modern calciner kiln with an ILC-system is summarized in Table 1. 


\subsection{Combustion of fuels in cement plants}

During the last 20-30 years, an increasing amount share of alternative fuels has been used in the cement industry, motivated by low fuel cost, reduced waste disposal problems, and increased environmental concern; alternative fuels may be partly or fully $\mathrm{CO}_{2}$-neutral ${ }^{9,25-29}$. The European cement industry recovers a substantial amount of waste-derived fuels, which replace fossil fuels up to a level of more than $80 \%$ in some individual plants ${ }^{24}$. In Germany, an average of $61 \%$ of the thermal energy for cement production came from alternative fuel sources in $2011^{30}$. The change in energy sources is illustrated by Figure 2 and Figure 3, which show the type of the fuels used in average by the cement industry in Europe, in 1990 and 2011, respectively.

\subsubsection{Usage of fossil fuels}

Coal, petroleum coke (petcoke), oil, and natural gas, which are the major fossil fuels, have been used as stand-alone fuels or in various combinations since the industrial revolution in the cement industry $^{32-34}$. Fossil fuels are non-renewable sources, and their usage has a significant environmental impact. Burning fossil fuels generates $\mathrm{NO}_{\mathrm{x}}$ that leads to acid rain and to air contamination, and $\mathrm{CO}_{2}$ that contributes to intensify the greenhouse effect.

Coal and petcoke, the most carbon-intensive fossil fuels, are the most widely-used fuels in the cement industry ${ }^{34,43,44}$. Table 2 shows typical proximate analyses and heating values of different fossil fuels. The composition of different coals used to fire cement kilns can vary considerable, as illustrated by the data in Table 2. The ash composition needs to be taken into account for in the contribution of the overall chemistry of the cement feed ${ }^{34,45,46}$, since the fuel content of $\mathrm{SiO}_{2}$ and $\mathrm{Al}_{2} \mathrm{O}_{3}$ will be incorporated into the clinker. The volatile content is important for the combustion characteristics and the fuel reactivity. Solid fuels are normally pulverized before use, 
and a required fuel fineness is needed according to the volatile content of the fuel in order to enable good combustion in the kiln and calciner ${ }^{33,45,46}$. Fossil fuels are typically introduced with a particle sieve residue of $2-20 \%$ on a $90 \mu \mathrm{m}$ sieve ${ }^{47}$. There exists an empirical rule, which relates the required coal fineness to the proximate of volatile matter content to obtain a definite content of unburned carbon in $\mathrm{ash}^{48}$. The coal ash needs to be sufficiently fine not to be a barrier to reactivity in the clinkering process ${ }^{49}$. Fossil fuels, especially petcoke (see section 2.1), are characterized by a high content of sulfur ${ }^{44,50-52}$.

\subsubsection{Usage of alternative fuels}

Alternative fuels cover a wide range of fuels, ranging from fossil fuel-based (e.g. waste oil, natural gas) to biomass based (e.g. all non-fossil fuels and waste from other industries). The utilization of alternative fuels such as car tires ${ }^{53}$, plastic waste, sewage sludge ${ }^{47,54}$ and wood waste $^{55}$, is continuously increasing. Some of the most common alternative fuels are industrial and municipal waste, refuse-derived fuel (RDF), tire-derived fuels (TDF), meat and bone meal (MBM), and wood waste. Table 3 shows typical proximate analyses, and heating values of different alternative fuels used in the cement industry.

The most important characteristics to consider for alternative fuels are the heating value, the ash composition and content, the particle size, and, the moisture content ${ }^{9}$. The fuel properties affect the thermal energy input as well as the process stability such as possible fuel spillage and modification of minor elements inputs. Fuel spillage can happen in the kiln flame and in the calciner and is considered when unburned fuel drops into the material bed. Alternative fuels may be introduced to the kiln system in the form of large particles in the range of millimetres and centimetres, which may prolong the time of conversion. The fuel ash, which is incorporated into 
the clinker chemistry, may modify the minor elements input and the composition balance of the raw materials.

Benefits of the substitution of fossil fuels by alternative fuels include reduction of fuel and production costs, partial or full $\mathrm{CO}_{2}$-neutrality, efficient use of waste as energy, and incorporation of the ash residue into the cement clinker. However, use of alternative fuels has some general requirements such as availability in large amounts, legislation and permissions before a specific alternative fuel can be used, and logistics for transport and handling of the specific fuel. The usage of alternative fuels varies widely across regions and countries and depends on local conditions. Cement plants located in the European Union, which use alternative fuels are subject to Directive 2010/75/EU about industrial emissions ${ }^{68}$. The increasing use of alternative fuel concerns the hazard gaseous emissions, such as $\mathrm{HCl}, \mathrm{HF}, \mathrm{NO}_{\mathrm{x}}$ and heavy metals. Emissions of $\mathrm{HCl}$ and $\mathrm{HF}$ from cement kilns are typically negligible compared to municipal solid waste incinerators because cement kilns operate under alkaline conditions. This ensures that chlorine and fluorine are bound as salts rather than $\mathrm{HCl}$ and $\mathrm{HF}$ in cement kilns ${ }^{69}$. Several investigations have been made to address the effect of co-firing alternative fuels $\left(\mathrm{MBM}^{70,71}\right.$, tyres ${ }^{72,73}, \mathrm{RDF}^{71}$ and plastics ${ }^{74}$ ) on $\mathrm{NO}_{\mathrm{x}}$ emissions. It was observed that $\mathrm{NO}_{\mathrm{x}}$ emissions generally decreases when alternative fuels were used, because NOx formed from the kiln or from fuel Nrelease during pyrolysis is reduced to $\mathrm{N}_{2}$. The $\mathrm{NO}_{\mathrm{x}}$ reduction is attributed to the higher volatile content and hence higher reduction potential ${ }^{75}$. Amongst the heavy metals, emissions of $\mathrm{Hg}$ and $\mathrm{Tl}$ are the most relevant to consider due to their high volatility. These elements are involved in recirculation cycles between the raw mill/particle filter and the upper preheater stages, as 
explained in the introduction of section 2. Care should be exerted with fuels containing relatively high amounts of Hg, e.g. municipal solid waste (MSW), RDF and sewage sludge ${ }^{76}$.

The calciner and the main burner have been subject to modifications to optimize the combustion of alternative fuels. Despite these modifications, the usage of relatively small particles in the calciner and in the kiln burner is required to ensure a sufficient fuel burnout and the desired flame profile. A consequence of firing large alternative fuels particles is that the partially or unburned solid fuels may drop into the material charge. Moreover, coarse alternative fuels are sometimes fired directly into the material inlet end of the rotary kiln, because this solution requires minimal shredding. The solid fuels can end up in the material charge in the rotary kiln in four different ways ${ }^{21}$, which are illustrated in Figure 4, and outlined briefly below;

1. Large solid fuel particles fired in the calciner may be too heavy to be carried upwards with the gas flow and drop through the riser duct into the rotary kiln.

2. Large solid fuels particles fired through the kiln burners may not be completely combusted in the flame of the main burner and fall into the material charge.

3. Small and unconverted solid fuel particles, which are light enough to be carried upwards with the gas flow through the calciner and transported into the cyclones, can fall into the kiln inlet with calcined raw meal.

4. Coarse solid fuels may be fired directly into the rotary kiln material inlet end.

The consequences of the combustion of alternative fuels in these conditions and locations are:

- Direct physical contact between the fuels and the cement raw materials

- Local reducing conditions in the material bed of the rotary kilns

- Potential increase of internal circulation of $\mathrm{S}, \mathrm{Cl}$ and alkali metal species 
These consequences lead to modification of the process conditions and may affect the clinker quality and the process operation causing build-ups, blockages and/or corrosion.

New types of combustion equipment have been developed to optimize the combustion, minimize the harmful emissions, and avoid operational challenges when alternative fuels are used in the traditional firing points of cement plants. The technologies for alternative fuel combustion can be divided into:

- External reactors, which are typically placed next to the calciner, operating in excess oxygen $^{77-80}$ or under low-oxygen conditions (gasifiers) ${ }^{81-83}$. The common concept is to use the high heating value gas in the calciner and incorporate ash residues into the cement chemistry.

- New kiln burners, especially designed to combust alternative fuels, which may involve a compromise between high substitution rates of alternative fuels and low $\mathrm{NO}_{\mathrm{x}}$ emissions $^{84}$. A detailed review of rotary kiln burner design configurations for alternative fuels co-firing may be found elsewhere ${ }^{85}$.

- Oxygen enrichment in the rotary kiln (oxy-fuel combustion) has been demonstrated on a commercial scale to increase the alternative fuel utilization, decrease emissions, and improve the kiln performance and productivity ${ }^{86,87}$. This technology offers opportunity to optimize the combustion process with respect to temperature and composition of the oxidizer. However, the major drawback is the high cost, which must be balanced with possible fuel cost and process savings ${ }^{84,88}$, and for that reason this technology is not commonly used in the cement industry ${ }^{87}$.

- New kiln designs as emerging technologies have also been patented but are not currently been installed in any cement plant ${ }^{89,90}$. 


\section{Circulation of Inorganic Volatiles Elements}

Sulfur, $\mathrm{Cl}, \mathrm{Na}, \mathrm{K}, \mathrm{Pb}, \mathrm{Tl}, \mathrm{Hg}, \mathrm{Zn}$, and $\mathrm{Cd}$ are inorganic elements entering the kiln with the raw materials and fuel. They evaporate partly in the burning zone of the kiln and condense on the incoming raw meal or on plant surfaces in the cooler parts of the kiln system. By repetitive evaporation and condensation, these elements circulate in the cement plant at different temperatures and locations of a cement plant.

$\mathrm{Tl}, \mathrm{Pb}, \mathrm{Zn}$ and $\mathrm{Cd}$ are considered low or semi-volatile metals and may be introduced when burning contaminated waste. Sprung et al. ${ }^{91,92}$ studied the behaviour of $\mathrm{Pb}$ and $\mathrm{Zn}$ in the kiln through full-scale tests. From material balances it appeared that, on average, around $86 \%$ of the Zn was incorporated in the clinker, while the rest was taken up in the dust. The results indicated that about half of $\mathrm{Pb}$ was captured in the clinker and the other half was taken up in the dust ${ }^{92} . \mathrm{Pb}$ and $\mathrm{Zn}$ may react with $\mathrm{Cl}$ above $600^{\circ} \mathrm{C}$, according to equilibrium calculations ${ }^{93}$, and these chlorides may condense on the dust of the preheater tower and be carried out of the system with the gas stream. Thallium circulation occurs in the upper stage of the preheater, exiting the system and condensing on the dust in the main baghouse filter. Less than $15 \%$ of $\mathrm{Tl}$ entering the kiln will exit with the clinker ${ }^{94}$. Mercury is highly volatile heavy metal and more than $90 \%$ of the $\mathrm{Hg}$ escapes through the stack, while other heavy metals such $\mathrm{As}, \mathrm{Cd}, \mathrm{Cu}, \mathrm{Cr}$, and $\mathrm{V}$ are primarily incorporated into the clinker ${ }^{11}$. Mercury may form sulfates and chlorides with boiling and melting points in the temperature range $270-600^{\circ} \mathrm{C}^{94}$. Mercury evaporates in the upper preheater stages. If the temperature in the raw mill and particle filter of the flue gas cleaning system is sufficiently low, $\mathrm{Hg}$ may re-condense on the solid particles and be transferred back to the preheater and re-evaporate in the upper preheater stages ${ }^{94}$. Therefore, mercury is only removed 
with the preheater dust. This results in an external recirculation between the raw mill/particle filter and the upper preheater stages. Mercury has its own circulation mechanism and and has only a negligible impact on the recirculation of S, Cl, K and Na. The work of Paone ${ }^{94}$ and Zheng et al. ${ }^{95,96}$ explain in further details the mechanism of mercury release and capture.

None of these aforementioned elements causes any operational problems and will not be addressed further in the present work. This article will focus on $\mathrm{S}, \mathrm{Cl}, \mathrm{Na}$ and $\mathrm{K}$, which are the volatile elements that influence the process stability and kiln operation through deposit build-ups and corrosion.

\subsection{Volatile elements in raw materials and in fuels}

Sulfur, $\mathrm{Cl}, \mathrm{K}$, and $\mathrm{Na}$ are introduced in the kiln system through the raw meal and the fuels. Table 4 lists the range of the concentrations of $\mathrm{Na}$ and $\mathrm{K}$ expressed as oxides (due to the elements analysis method), $\mathrm{S}$ expressed as $\mathrm{SO}_{3}$, and $\mathrm{Cl}$ found in different raw materials.

The concentrations of these elements in fossil and alternative fuels are presented in Table 5 . Chlorine is mainly introduced to the kiln system through the fuels, rather than by raw materials, while alkali metals are mostly provided by the raw materials. Biomass fuels, such as wood waste and straw, contain 5-10 times less S compared to fossil fuels. Sulfur can also be found in waste derived fuels, e.g. in car tires as a vulcanizer.

\subsubsection{Reaction Affinity between Volatile Elements}

The circulating elements have a strong affinity for other elements and form chemical species like chlorides and sulfates. The following order of affinity has been observed ${ }^{11,34,102}$ : 
1. The chlorine reacts primarily with alkali metals, forming $\mathrm{KCl}$ and/or $\mathrm{NaCl}$, typically in gas phase. The residual chlorine combines with calcium, forming $\mathrm{CaCl}_{2}(\mathrm{~s} / \mathrm{l})$. However, the input of chlorine is seldom higher than the input of alkali.

2. The excess alkali reacts with sulfur, forming $\mathrm{K}_{2} \mathrm{SO}_{4}$ and/or $\mathrm{Na}_{2} \mathrm{SO}_{4}$. The residual alkali combines with $\mathrm{CO}_{2}$, forming $\mathrm{K}_{2} \mathrm{CO}_{3}$ and $\mathrm{Na}_{2} \mathrm{CO}_{3}{ }^{103}$ or with moisture, forming $\mathrm{NaOH}$ and $\mathrm{KOH}$. The alkali can also be embedded in clinker minerals.

3. The excess $\mathrm{S}$, present as $\mathrm{SO}_{2}$ and/or $\mathrm{SO}_{3}$ in the gas, will react with $\mathrm{CaO}(\mathrm{s})$, forming $\mathrm{CaSO}_{4}(\mathrm{~s})$.

The extent of circulation is determined by the volatility of the compounds, i.e., the portion that is volatilized at high temperature in the kiln system and therefore not leaves the kiln with the clinker. The volatility is described using an evaporation factor, $\varepsilon$, for each compound varying from 1 to 0 , where 1 means that all volatile compounds evaporate at high temperature (but not necessarily escapes to the atmosphere), and 0 that none is evaporated in the kiln system; all of it leaves with the clinker. An intermediate value of $\varepsilon$ indicates the fraction of the element that will be evaporated at high temperature (and subsequently condense at cooler parts), while the fraction leaving with the clinker is indicated by $1-\varepsilon$.

\subsubsection{Circulation of Sulfur}

The S-circulation is the most complex. An illustration of the S-containing species and their transformation at different locations in a cement plant is shown in Figure 5. Sulfur can be introduced to cement rotary kilns through the raw meal and through the fuels. In the preheater system, the organic sulfur and the pyrite from the raw meal are oxidized, thereby releasing $\mathrm{SO}_{2}$ upon heating in an oxidizing environment. The oxidation of sulfur species (pyrite and organic 
sulfur impurities) occurs between 300 and $600^{\circ} \mathrm{C}$, corresponding to the temperature in the first or second cyclone in a preheater tower ${ }^{104}$. The decomposition of pyrite has been reviewed by Hu et al. ${ }^{105}$, who found that in an atmosphere containing oxygen, pyrite can decompose by direct oxidation, eqn. (1), or by thermal decomposition of pyrite to pyrrhotite and sulfur, followed by subsequent oxidation to $\mathrm{SO}_{2}$, eqn. (2). Iron sulfates may also be formed as minor products during the oxidation of pyrite in a gas rich in $\mathrm{SO}_{2}$ at temperatures lower than $600-650^{\circ} \mathrm{C}{ }^{105}$.

$$
\begin{aligned}
& 2 \mathrm{FeS}_{2}(\mathrm{~s})+5.5 \mathrm{O}_{2} \rightarrow \mathrm{Fe}_{2} \mathrm{O}_{3}(\mathrm{~s})+4 \mathrm{SO}_{2}(g) \\
& 2 \mathrm{FeS}_{2}(\mathrm{~s}) \rightarrow 2 \mathrm{FeS}_{x}(\mathrm{~s})+2(1-0,5 x) \mathrm{S}_{2}(g) \stackrel{\mathrm{O}_{2}(g)}{\longrightarrow} \mathrm{Fe}_{2} \mathrm{O}_{3}(s)+4 \mathrm{SO}_{2}(g)
\end{aligned}
$$

The gases leaving the preheater tower are used for drying the raw materials in the raw meal mill and a portion of the $\mathrm{SO}_{2}$ will be captured, and thereby the $\mathrm{SO}_{2}$ emissions will be lowered. Of the sulfur entering with the raw meal in the form of pyrites, it is often assumed that $30-50 \%$ will leave the preheater tower as $\mathrm{SO}_{2}{ }^{106-108}$. However, the amount $\mathrm{SO}_{2}$ leaving the preheater tower can range from 10 to $65 \%{ }^{108}$.

The $\mathrm{SO}_{2}$ coming from the rotary kiln is led to the calciner where the good gas-solid mixing and the temperature favor capture of the $\mathrm{S}^{108-110}$. The sulfation of $\mathrm{CaO}$ with $\mathrm{SO}_{2}$ has been recognized as a complex, high-temperature, fast heterogeneous process, limited by gas-phase and solidphase diffusion, with simultaneous physical transformation of the solid ${ }^{111}$. The sulfation process can follow a number of routes, and in the literature, there is a lack of agreement on the mechanism. Two possible routes of sulfation have been discussed by Moss ${ }^{112}$, who examined the sulfation mechanisms. It may proceed either via formation of $\mathrm{CaSO}_{3}$ or via conversion of $\mathrm{SO}_{2}$ to $\mathrm{SO}_{3}$, followed by reaction of $\mathrm{SO}_{3}$ with $\mathrm{CaO}$ to form $\mathrm{CaSO}_{4}$ :

$$
\mathrm{CaO}(\mathrm{s})+\mathrm{SO}_{2}(\mathrm{~g}) \rightleftarrows \mathrm{CaSO}_{3}(\mathrm{~s})
$$




$$
\mathrm{CaSO}_{3}(s)+\frac{1}{2} \mathrm{O}_{2}(g) \rightleftarrows \mathrm{CaSO}_{4}(s)
$$

or

$$
\begin{aligned}
& \mathrm{SO}_{2}(g)+\frac{1}{2} \mathrm{O}_{2}(g) \rightleftarrows \mathrm{SO}_{3}(g) \\
& \mathrm{CaO}(\mathrm{s})+\mathrm{SO}_{3}(\mathrm{~g}) \rightleftarrows \mathrm{CaSO}_{4}(\mathrm{~s})
\end{aligned}
$$

Moss suggested that the reaction proceeds via the formation of $\mathrm{CaSO}_{3}$ (i.e. reaction (3) and (4)) at temperatures lower than $850^{\circ} \mathrm{C}$, where $\mathrm{CaSO}_{3}$ is thermally stable, while reactions (5) and (6) dominate at temperatures above $850^{\circ} \mathrm{C}^{112}$. The gas phase equilibrium favors formation of $\mathrm{SO}_{3}$ below $1000^{\circ} \mathrm{C}$, and the equilibrium level of $\mathrm{SO}_{3}$ increases with decreasing temperature. The second route has been supported by many authors ${ }^{113-117}$, although $\operatorname{Lin}^{114}$ suggested that both mechanisms might take place. Hu et al. ${ }^{117}$ discussed the influence of the reaction conditions, such as $\mathrm{SO}_{2}, \mathrm{O}_{2}, \mathrm{CO}_{2}$, and $\mathrm{H}_{2} \mathrm{O}$ gas concentrations, limestone properties, reaction mechanism and modeling of the direct sulfation reaction via the second route. Kinetic studies have shown that the rate of reaction of $\mathrm{CaO}$ with $\mathrm{SO}_{2} / \mathrm{O}_{2}$ mixture is similar to that of the direct reaction with $\mathrm{SO}_{3}{ }^{118,119}$. No accurate $\mathrm{SO}_{3}$ concentration measurements have been reported. Possibly both routes are active, but this is out of the scope of this review.

Calcium sulfate, $\mathrm{CaSO}_{4}$, is incorporated in the hot meal entering the rotary kiln where it is gradually heated, and a sulfate melt is formed at around $1200^{\circ} \mathrm{C}^{120}$. In the transient zone of the kiln, two immiscible liquids may occur at equilibrium: an oxide melt containing $\mathrm{Al}_{2} \mathrm{O}_{3}, \mathrm{Fe}_{2} \mathrm{O}_{3}$ and $\mathrm{SiO}_{2}$, and a sulfate melt, in which $\mathrm{Al}_{2} \mathrm{O}_{3}, \mathrm{Fe}_{2} \mathrm{O}_{3}$ and $\mathrm{SiO}_{2}$ are nearly insoluble ${ }^{34}$. In a purely homogenous mixture, no liquid phases are formed below $1338^{\circ} \mathrm{C}^{121,122}$, where an eutectic in $\mathrm{CaO}-\mathrm{Al}_{2} \mathrm{O}_{3}-\mathrm{Fe}_{2} \mathrm{O}_{3}-\mathrm{SiO}_{2}$ system exists. Nevertheless, local inhomogeneities in the raw meal 
mixture cause a shift of the eutectic toward lower temperatures ${ }^{122}$. For further explanation on the liquid phases, we refer to the review by Telschow et al. ${ }^{14}$.

In the burning zone, where the bed material reaches its maximum temperature of around $1450^{\circ} \mathrm{C}$, evaporation of $\mathrm{S}$ takes place forming $\mathrm{SO}_{2}, \mathrm{~K}_{2} \mathrm{SO}_{4}$ and $\mathrm{Na}_{2} \mathrm{SO}_{4}$ in the gas phase ${ }^{120}$. The alkali sulfates in the gas phase are transported with the hot gases and the dust along the rotary kiln. As the gas cools down, alkali sulfates condense on dust particles, suspended in the kiln gases. The condensation product obtained between 700 and $800^{\circ} \mathrm{C}$ is a melt, but at lower temperatures, condensation may result in a solid. Dust particles are incorporated in the solid stream in the calciner, and alkali sulfates re-enter then with the hot meal into the rotary kiln. Here, they are partly incorporated in the sulfate melt, thereby improving the chemical reactivity of the material in the kiln and lowering the viscosity of the melt, which can facilitate some of the clinker reactions $^{120}$.

Thus, an internal S-cycle is established in the rotary kiln and the calciner, as illustrated in Figure 6; a Sankey diagram, in which the width of the lines, are proportional to mass flow. This is a schematic representation made by Nielsen and Jepsen ${ }^{106}$, using data from 12 preheater kiln systems in the US. The $\mathrm{SO}_{2}$ coming from the kiln is absorbed by the raw meal in the calciner, and introduced in the kiln. This results in a significant circulation between the inlet of the rotary kiln and the calciner, involving both the incoming material and the outgoing kiln gases. The mass flow of sulfates in the kiln inlet is approximately three times the mass flow in the outlet.

The fraction of $\mathrm{S}$ released as $\mathrm{SO}_{2}$ depends on the sulfur to alkali ratio in the rotary kiln ${ }^{123}$, which is defined in equation (7), and expresses the proportion of sulfur that can be bound with alkali. 


$$
\frac{\mathrm{SO}_{3}}{A l k}=\frac{\frac{w_{\mathrm{SO}_{3}, \text { LOI free }}}{M_{\mathrm{SO}_{3}}}}{\frac{w_{\mathrm{K}_{2} \mathrm{O}, \text { LOI free }}}{M_{\mathrm{K}_{2} \mathrm{O}}}+\alpha \cdot \frac{w_{\mathrm{Na}_{2} \mathrm{O}, \mathrm{LOI} \text { free }}}{M_{\mathrm{Na}_{2} \mathrm{O}}}}
$$

where $\mathrm{M}_{\mathrm{i}}$ is the molar mass of the component $i, \alpha$ is the fraction of $\mathrm{Na}_{2} \mathrm{O}$ that reacts with $\mathrm{SO}_{3}$, and $\mathrm{w}_{\mathrm{i}}$, LOI free is the total input concentrations of species $i$, being $\mathrm{SO}_{3}, \mathrm{~K}_{2} \mathrm{O}$ and $\mathrm{Na}_{2} \mathrm{O}$ (representing S, K, and $\mathrm{Na}$, respectively) in wt. \% loss on ignition free base. The loss on ignition (LOI) is equivalent to the loss in mass that it will undergo in a kiln (free of $\mathrm{H}_{2} \mathrm{O}$ and $\mathrm{CO}_{2}$ from carbonates) and indicates how complete the calcination processing is. From practical experience, $\alpha$ has the value of 0.5 because there is substantial excess of $\mathrm{K}_{2} \mathrm{O}$ over $\mathrm{Na}_{2} \mathrm{O}^{124}$ and analyses of different clinker compositions have revealed that nearly the entire amount of $\mathrm{K}$ and half the amount of $\mathrm{Na}$ form sulfate ${ }^{97,125}$.

The optimum $\mathrm{SO}_{3} / \mathrm{Alk}$ ratio is close to 1 , for a low evaporation of sulfur ${ }^{126-129}$ because in this case there will be sufficient alkali for formation of alkali sulfates, rather than formation of $\mathrm{SO}_{2}$ ${ }^{123}$. If the $\mathrm{SO}_{3} / \mathrm{Alk}$ ratio is lower than 1 , the $\mathrm{S}$ is bound but there is an excess of alkali, which lead to alkali circulation forming $\mathrm{KOH}$ and $\mathrm{NaOH}$ in gas phase $\mathrm{s}^{34,130}$. Alkali carbonates can also be formed when the $\mathrm{SO}_{3} /$ Alk ratio is lower than 1. If the ratio is higher than 1, there will be an amount of sulfur in the kiln material which cannot be captured by alkali. The behavior of the $\mathrm{SO}_{3} /$ Alk has been confirmed by thermodynamic calculations ${ }^{34}$.

The excess of $\mathrm{S}$ in the raw materials to form $\mathrm{CaSO}_{4}$ is termed excess $\mathrm{SO}_{3}$, usually expressed as g excess $\mathrm{SO}_{3} / 100 \mathrm{~kg}$ clinker, and may be calculated by the equation $(8)^{109}$.

$$
\text { Excess } \mathrm{SO}_{3}=w_{\mathrm{SO}_{3}, \text { LOI free }}-\frac{M_{\mathrm{SO}_{3}}}{M_{\mathrm{K}_{2} \mathrm{O}}} \cdot w_{K_{2} \mathrm{O}, \mathrm{LOI} \text { free }}-\alpha \cdot \frac{M_{\mathrm{SO}_{3}}}{M_{\mathrm{Na}_{2} \mathrm{O}}} \cdot w_{\mathrm{Na}_{2} \mathrm{O}, \text { LOI free }}
$$


The limit on excess-S is given to be in the range of $250-600 \mathrm{~g} / 100 \mathrm{~kg}$ clinker ${ }^{131,132}$. The lower limit is for low reactivity raw meal, and the upper limit is for high reactivity raw meal. The reactivity of the raw meal is determined by the burnability, which is a measurement of how easy/difficult the clinker phases are formed. The excess $\mathrm{S}$ will form $\mathrm{CaSO}_{4}$, which is the least thermally stable sulfate ${ }^{123,133}$ and will be contributing to a higher evaporation factor.

The S-volatility depends on the $\mathrm{SO}_{3} / \mathrm{Alk}$ ratio and on the operating conditions of the kiln, i.e.:

- $\quad$ The oxygen content of the kiln atmosphere. Deficiency of oxygen or a local reducing kiln atmosphere increases the volatility of S, because low oxygen level shifts eqn. (9) to the right ${ }^{34,134}$.

$\mathrm{CaSO}_{4}(\mathrm{~s}) \rightleftarrows \mathrm{CaO}(\mathrm{s})+\mathrm{SO}_{2}(\mathrm{~g})+\frac{1}{2} \mathrm{O}_{2}(\mathrm{~g})$

Figure 7 shows the $\mathrm{SO}_{2}$-bypass emissions as function of $\mathrm{O}_{2}$-concentration in the kiln inlet. At higher $\mathrm{O}_{2}$-concentrations, the $\mathrm{SO}_{2}$ evaporation is suppressed, and there will be little $\mathrm{SO}_{2}$ in the material inlet of the rotary kiln. However, when the oxygen level in the kiln material inlet gets below around 2 vol. \%, the S evaporation increases steeply, and the bypass emissions can increase significantly ${ }^{135}$. At lower oxygen concentrations, reduced S-species such as $\mathrm{H}_{2} \mathrm{~S}$, COS in presence of carbon, and $\mathrm{SOCl}_{2}$ in presence of $\mathrm{Cl}$ may also be formed; however, these species are not measured in cement plants.

- Temperature in the burning zone. The volatility of the S-species is increasing as a function of temperature. Thermal decomposition is avoided by lowering the burning zone temperature. This may be achieved by making the raw meal more chemically reactive, which means finer grinding of the raw meal or modifying the chemical composition. If the raw meal has a low reactivity, it needs higher temperatures in order to get a low free 
lime in the clinker. Therefore, low reactivity raw mixtures or overheating of the clinker have a high impact on S-volatility ${ }^{34}$.

The sulfur volatility can also be modified by fuels in the bed material, which will be further explained in section 4. Under stable operational conditions, and if there is sufficient alkali available to capture the input $S$, the volatility of S may range between 0.35 and $0.6^{124}$.

During nodulization, the sulfate melt can be trapped in the inner core of the clinker nodules ${ }^{136}$. The sulfate melt reaching the clinker cooler will subsequently crystalize in the clinker. The composition of the sulfate melt at the end of the burning zone will determine the mixture of compounds that will solidify according to the tertiary diagram of $\mathrm{CaSO}_{4}-\mathrm{K}_{2} \mathrm{SO}_{4}-\mathrm{Na}_{2} \mathrm{SO}_{4}$, illustrated in Figure 8. There are three primary precipitation areas, corresponding to $\mathrm{CaSO}_{4}$, $\mathrm{K}_{2} \mathrm{SO}_{4} \cdot 2 \mathrm{CaSO}_{4}$ (calcium langbeinite) and (K,Na,Ca)SO $\mathrm{SO}_{4}$ (aphthitalite). If the composition of the melt is located in one of precipitation areas, the species of that area will precipitate first.

Sulfur in the Portland cement clinker is mainly found as $\mathrm{Na}_{2} \mathrm{SO}_{4}, \mathrm{~K}_{2} \mathrm{SO}_{4}, \mathrm{CaSO}_{4},\left(\mathrm{~K}_{\mathrm{x}}, \mathrm{Na}_{\mathrm{y}}\right) \mathrm{SO}_{4}$ (aphthitalite), $\mathrm{K}_{2} \mathrm{SO}_{4} \cdot 2 \mathrm{CaSO}_{4}$ (calcium langbeinite), and as substituents in the major clinker phases, mainly alite and belite with little in the ferrite ${ }^{138,139}$. For most common Portland cement, the upper acceptable limit of $\mathrm{S}$ expressed as $\mathrm{SO}_{3}$ in clinker, in order to assure good quality, is 1.6 wt. $\%{ }^{138,139}$. More than half of the $\mathrm{S}$ originating from raw materials and fuel appears in the clinker; the rest is lost in the flue gas and in the kiln dust ${ }^{97}$.

Amounts of S larger than 2.6 wt. $\% \mathrm{SO}_{3}$ in clinker ${ }^{140}$ have an adverse impact on the clinker mineral formation, inhibiting alite formation and promoting stabilization of belite and free lime, which needs to be lower than $1.5 \mathrm{wt} . \% \mathrm{CaO}$ in clinker. One measure to prevent this phenomenon is to add calcium fluoride $\left(\mathrm{CaF}_{2}\right)$ to the raw meal, as a mineralizer. This allows lowering the burning temperature, and consequently the formation of alite is accelerated and the burnability 
(the reactivity of the solid material) is improved. However, concentrations higher than $0.25 \mathrm{wt}$. $\% \mathrm{CaF}_{2}$ in clinker are negatively affecting the cement properties, resulting in retarded setting, reduced early strength, and increased late strength ${ }^{34,124,141,142}$.

\subsubsection{Circulation of Chlorine}

The Cl-circulation and the locations of the formation of different Cl-species in a cement plant are illustrated in Figure 9. The chlorine, as chlorides, is frequently found in limestone and clays, predominantly as $\mathrm{NaCl}$. The raw meal contains relatively small amounts of $\mathrm{Cl}$, typically in the range $0-0.03$ wt. $\%$ and mostly less than 0.01 wt. \% LOI. For ILC-kiln systems without a bypass, the maximum $\mathrm{Cl}$-concentration allowed in the raw meal is 0.029 wt. \% on clinker basis; higher concentrations will cause heavy build-up problems in the kiln ${ }^{143}$.

Chlorine can be released during the combustion of fuels, and the Cl-input from fuels can vary significantly, depending on the type of fuel. The Cl-content in fossil fuels, such as coal and petcoke, is rather low, but it can be significant for alternative fuels, such as RDF, as presented in Table 5. The possible paths and release mechanisms of $\mathrm{Cl}$ during pyrolysis and combustion of biomass can be found in ${ }^{144}$. $\mathrm{HCl}$ is formed when fuels containing organically bound chlorine or inorganic chloride salts are burned ${ }^{145}$. Organically associated $\mathrm{Cl}$ can also be released in the gas phase as $\mathrm{CH}_{3} \mathrm{Cl}^{146}$. In the calciner, and along lower preheater stages, the $\mathrm{HCl}$ will be absorbed by free lime according to reaction $(10)^{124,147}$; however the absorption of $\mathrm{HCl}$ by limestone is strongly dependent on the humidity of the flue gas ${ }^{148}$. The absorption of $\mathrm{HCl}$ by limestone has been extensively studied by Partanen ${ }^{145,148-150}$.

$$
\mathrm{CaO}(\mathrm{s})+2 \mathrm{HCl}(\mathrm{g}) \rightleftarrows \mathrm{H}_{2} \mathrm{O}(\mathrm{g})+\mathrm{CaCl}_{2}(\mathrm{~s} / \mathrm{l})
$$


In the burning zone, there is no reactive free $\mathrm{CaO}$ suspended in the flame, and $\mathrm{HCl}$ from the kiln fuel will therefore be transported to the preheater and be converted to $\mathrm{CaCl}_{2}$ there. In the calciner and the lower cyclone stages, at temperatures of $800-850^{\circ} \mathrm{C}$, the $\mathrm{Cl}$-species from the raw materials can melt, and condensation of Cl-species from the kiln gases also occurs. Therefore, the Cl-species are present in liquid phase. The inverse reaction of equation 10 can also occur in presence of moisture.

In the burning zone, only the chlorine salts $\mathrm{KCl}$ and $\mathrm{NaCl}$ evaporate from the sulfate melt. The $\mathrm{Cl}$ has an evaporation factor range of 0.900 to 0.996 , and will evaporate nearly $100 \%{ }^{124,147,151}$. The boiling temperatures of $\mathrm{KCl}$ and $\mathrm{NaCl}$ are approximately $1400^{\circ} \mathrm{C}$. The circulation is determined by the phase equilibrium between liquid and gaseous $\mathrm{KCl}$.

Figure 10 shows a Sankey diagram for Cl-circulation, showing how the gaseous, liquid and solid $\mathrm{Cl}$ flows. The Sankey diagram was made based on data from a Finnish cement plant, and the diagram is only valid for low $\mathrm{Cl}$ circulation ${ }^{147}$. The $\mathrm{Cl}$ has a considerable circulation around the calciner, leading to high Cl-concentration. As an approximation, the $\mathrm{Cl}$ mass flow in the kiln inlet is 200 times greater than the accumulated mass flow in the outlet.

High values of the $\mathrm{SO}_{3} / \mathrm{Alk}$ ratio are critical for the circulation of chlorides, because sulfation of alkali chlorides can take place at temperature higher than $900^{\circ} \mathrm{C}$, according to the general reaction (11), where $\mathrm{M}$ can be $\mathrm{Na}$ or $\mathrm{K}$. Alkali sulfates can be either solid or gaseous depending on the temperature, and whether or not aerosol formation occurs, i.e., dependent on the local concentration and cooling rate. Reaction (12) shows a pathway for sulfation of $\mathrm{CaCl}_{2}$, involving $\mathrm{SO}_{2}$. The combination of $\mathrm{HCl}$ and $\mathrm{SO}_{2}$, in the presence of moisture, makes the kiln gas very corrosive, causing corrosion on the steel walls of the rotary kiln. Sulfation is enhanced by the presence of chlorides in the middle zone of the kiln ${ }^{151}$. The chlorine and sulfur species are also 
responsible for deposit build-ups on the non-moving parts coatings caused by formation of chloroellestadite ${ }^{34}$, see section 3.

$$
\begin{aligned}
& 2 \mathrm{MCl}(g)+\frac{1}{2} \mathrm{O}_{2}(g)+\mathrm{SO}_{2}(g)+\mathrm{H}_{2} \mathrm{O}(g) \rightarrow \mathrm{M}_{2} \mathrm{SO}_{4}(g / l)+2 \mathrm{HCl}(g) \\
& \mathrm{CaCl}_{2}(g)+\frac{1}{2} \mathrm{O}_{2}(g)+\mathrm{SO}_{2}(g)+\mathrm{H}_{2} \mathrm{O}(g) \rightarrow \mathrm{CaSO}_{4}(g / l)+2 \mathrm{HCl}(g)
\end{aligned}
$$

Hydrolysis of alkali chlorides in the gas phase contributes to the formation of $\mathrm{HCl}$ according to reaction (13), especially at the temperatures of the burning zone. However, the formation of $\mathrm{HCl}$ through reaction (13) at temperatures below $1000-1150^{\circ} \mathrm{C}$ is limited, because it is thermodynamically restricted ${ }^{151}$.

$$
\mathrm{KCl}(\mathrm{g})+\mathrm{H}_{2} \mathrm{O}(\mathrm{g}) \rightleftarrows \mathrm{KOH}(\mathrm{g})+2 \mathrm{HCl}(g)
$$

The chlorine can be found in the clinker as $\mathrm{CaCl}_{2}$, and sometimes as $\mathrm{KCl}$, if it is trapped in the inner core of the clinker nodules. Most of the standards for Portland cement restrict the content of chloride to $0.1 \mathrm{wt} \%$, in order to avoid problems of reinforcement corrosion in concrete $^{11,148,152}$.

\subsubsection{Circulation of Alkali}

Circulation of alkali metals, which are mainly introduced by the raw materials, is represented in Figure 11. It is well known, that K-species are usually more volatile than Na-species ${ }^{124}$, see Figure 12. The intensity of the alkali cycle depends upon the nature of the alkali metals in the raw material, on operating practices, and on the actual type of kiln applied ${ }^{153}$. The limiting content of $\mathrm{Na}_{2} \mathrm{O}$ and $\mathrm{K}_{2} \mathrm{O}$ is generally expressed as $\mathrm{Na}_{2} \mathrm{O}$ equivalent, defined as;

$$
w_{\mathrm{Na}_{2} \mathrm{O} \text {, equiv }}=w_{\mathrm{Na}_{2} \mathrm{O}, \mathrm{LOI} \text { free }}+\frac{M_{\mathrm{Na}_{2} \mathrm{O}}}{M_{\mathrm{K}_{2} \mathrm{O}}} \cdot w_{\mathrm{SO}_{3}, \text { LOI free }}
$$


The source of alkali is most commonly clay or shale, but alkali can also be present in some limestones, sands and frequently in various types of alternative raw materials such as fly ashes. The average alkali concentrations are 0.17 wt. $\% \mathrm{Na}_{2} \mathrm{O}$ and 0.57 wt. $\% \mathrm{~K}_{2} \mathrm{O}$ for the raw materials 124. In most cases the alkali input by fossil fuels and/or by alternative fuels is rather small or negligible, except for cases with high alkali content in the ash, i.e. bituminous coal ${ }^{154}$.

In the preheater tower, alkali may be bound as sulfates, chlorides or carbonates. In the calciner, alkali sulfates are incorporated in the raw meal. If the alkali is not balanced by sulfates, they will remain very volatile and accumulate in the circulation between the kiln and the preheater. Jawed and Skalny ${ }^{97,155}$ and Skalny and Klemm ${ }^{156}$ have reviewed in detail the effects of alkalis in cement manufacture and use. They found that the mineralogical composition of raw materials producing volatiles is a major determinant of the alkali volatility. About $50 \mathrm{wt} \% \%$ of the alkali present in the raw feed is volatilized in the kiln between 800 and $1000^{\circ} \mathrm{C}^{97}$.

The acceptable range of $\mathrm{Na}_{2} \mathrm{O}$ and $\mathrm{K}_{2} \mathrm{O}$ concentration in the kiln riser varies from 3 to 5 wt. $\%$ LOI free ${ }^{34}$. Excess alkali has a potential to form alkali carbonates in the cyclones. Furthermore, too high alkali content without S-coverage may cause build-ups in the kiln riser or deposit buildups in the tertiary air pipe.

The alkali sulfates form part of the sulfate melt and remain trapped in the nodules as a liquid through the burning process. Porous clinker nodules tend to contain higher levels of alkali sulfates $^{137}$. Na and $\mathrm{K}$ act as fluxes (increasing the amount of melt formed at a given temperature) and mineralisers (accelerating the reaction rate and promotes the formation of alite within the liquid phase) for clinker formation, thereby improving the burnability of the clinker. For the cement properties, $\mathrm{Na}$ and $\mathrm{K}$ increase the early strength and lower the late strength ${ }^{124}$. Studies on the distribution of alkali in the clinker have confirmed that finer nodules contain lower alkali 
levels than courser nodules due to the higher surface available for alkali volatilization ${ }^{137-139}$. In the burning zone, alkali can evaporate as $\mathrm{NaOH}, \mathrm{KOH}, \mathrm{K}_{2} \mathrm{SO}_{4}$, and $\mathrm{Na}_{2} \mathrm{SO}_{4}$, as shown in Figure 11. Presence of $\mathrm{H}_{2} \mathrm{O}(\mathrm{g})$ in the kiln atmosphere promotes formation of alkali hydroxides, which are more volatile than the corresponding sulfates according to reaction (15). A similar reaction also takes place for $\mathrm{Na}^{34}$.

$$
\mathrm{H}_{2} \mathrm{O}(g)+2 \mathrm{~K}_{2} \mathrm{SO}_{4}(g) \rightarrow 4 \mathrm{KOH}(g)+2 \mathrm{SO}_{2}(g)+\mathrm{O}_{2}(g)
$$

The rest of the alkali, not being in the gas phase, recombines directly in the charge material with $\mathrm{Cl}$ or $\mathrm{S}$ or are integrated into the lattice of the clinker minerals, such as belite and aluminate. Alkali sulfates condense on dust particles at the exit gas temperature of the preheater tower. Furthermore, raw meal is added in the riser duct to favor the alkali sulfate condensation; otherwise the alkali sulfates would condensate on the walls of the riser duct, creating deposits. In this way, alkali sulfates in gas phase from the kiln are incorporated in the raw meal after the calciner.

The composition of the condensate will not be pure alkali sulfate but will include carbonates formed from $\mathrm{CO}_{2}$ from the gas stream and the clinker meal. Thus, the chemistry of the melt is an alkali sulfate and alkali carbonate melt, containing small amounts of alkali hydroxide. The presence of carbonate dissolved in the molten sulfate phase explains the presence of $\mathrm{CO}_{2}$ in the clinker analyses ${ }^{34}$.

In the presence of chlorides and sulfates, the volatilization behavior of both $\mathrm{Na}$ and $\mathrm{K}$ is modified greatly (depending on how $\mathrm{Na}$ and $\mathrm{K}$ are combined) as shown by the vapor pressurekiln temperature relationship in Figure 12. In the presence of $\mathrm{S}$, alkali preferentially forms sulfates, if $\mathrm{S}$ is present in amounts higher than the required stoichiometric balance ${ }^{34}$. 
Some of the $\mathrm{Na}_{2} \mathrm{O}$ and $\mathrm{K}_{2} \mathrm{O}$ are incorporated into aluminate, ferrite and belite. The residual alkalis will remain water soluble. Introduction of alkali into clinker minerals modifies their crystal structure, which may decrease the hydraulic reactivity of the cement ${ }^{97}$. Alkali compounds in the clinker can be divided into three main groups: ${ }^{1)}$ alkali sulfates, ${ }^{2)}$ alkali aluminates and alumino ferrites, and ${ }^{3)}$ alkali silicates ${ }^{97}$. In some cases, alkali may also occur in the form of carbonates ${ }^{97}$.

High levels of alkali in the final cement often lead to higher $\mathrm{pH}$, and early strength development, but lower later strengths. Soluble alkalis, which are not bound with S, may cause flash set (rapid and early loss of cement workability during water addition), due to activation of the calcium aluminates, and will also cause a significant loss of 28 days strength ${ }^{157}$. The maximum permissible content of alkali in the clinker is 0.6 wt. $\% \mathrm{Na}_{2} \mathrm{O}$ equivalent ${ }^{158,159}$. Alkali potentially can give rise to cracking and expansion in concrete, due to the alkali-silica reaction with reactive aggregates. In this situation, the alkali reacts with moisture and produces a gel, which expands ${ }^{34,160}$. Furthermore, a high concentration of alkalis in concrete has harmful effects on most mechanical properties of concrete, such as compressive, splitting, direct-tensile, and flexure strengths ${ }^{161}$.

\section{Consequences of High Inorganic Volatile Circulation}

\subsection{Deposit Build-up Formation}

The consequences of high internal circulation of inorganic elements are formation of build-ups and deposits. The gaseous species condense in the colder zones, and the condensation products are often chemically aggressive and with low melting temperatures. Therefore, the liquid present on the raw meal particles reduces the flowability of raw meal and causes the particles to stick to 
the walls. This may subsequently cause build-up on cyclone walls and riser ducts. Table 6 lists the common intermediate compounds found in build-ups and kiln rings and their typical location. Formation of build-ups may reduce the kiln production, and cause higher heat consumption, and kiln or plant stops, which are expensive.

Chemical analysis of the build-up samples from different cement kiln preheaters have shown that the main constituents are $\mathrm{SO}_{2}, \mathrm{~K}_{2} \mathrm{O}, \mathrm{CaO}$ and $\mathrm{Cl}$, and that their proportions may vary significantly, depending on their location ${ }^{164}$. The dominant phases in most of the samples were $\mathrm{CaSO}_{4}$, or a mixture of $\mathrm{CaSO}_{4}$ and $\mathrm{CaCO}_{3}$. Smaller amounts of other phases, such as ellestadite solid solution $\left(\mathrm{Ca}_{10}\left(\mathrm{SiO}_{4}\right)_{3}\left(\mathrm{SO}_{3}\right) \mathrm{Z}_{2}\right.$ where $\mathrm{Z}$ can be $\mathrm{OH}, \mathrm{F}$, or $\left.\mathrm{Cl}\right)$, more frequently chlorellestadite, $\mathrm{Ca}_{10}\left(\mathrm{SiO}_{4}\right)_{3}\left(\mathrm{SO}_{4}\right)_{3} \mathrm{Cl}_{2}$, and spurrite have also been reported. Microstructural examination showed that the growth of the rings was due to successive deposition of particles and condensation of gases. The main cause of the deposit formation appears to be the presence of a glassy phase, $\mathrm{K}_{1-\mathrm{x}} \mathrm{Na}_{\mathrm{x}} \mathrm{Cl}^{164}$, even in small quantities of $\mathrm{Cl}^{-}$. The system $\mathrm{KCl}-\mathrm{NaCl}$, illustrated in Figure 13, shows that $\mathrm{KCl}$ and $\mathrm{NaCl}$ melt from 660 to $800^{\circ} \mathrm{C}^{165}$, depending on the chlorides composition. In the presence of $\mathrm{CaSO}_{4}$, the liquid phase appears at lower temperatures, as shown in the corresponding tertiary diagram of reference ${ }^{164}$.

It has been stated that the presence of spurrite and $\mathrm{KCl}$ was found to be the reason for the build-up stability in the lower part of the preheater ${ }^{166}$. The investigation suggested a $\mathrm{KCl}$ crystallization model, based on a vapor-liquid-solid (VLS) mechanism, which is illustrated in Figure 14. The first step is the condensation of volatile elements on the grains of raw meal; then agglomerates are formed in the presence of a liquid phase and stick to the walls of the gas ducts, causing an increase in thickness of the solid material layer. Then, in the accretion formed, 
favorable conditions are created for $\mathrm{KCl}$ crystallization according to the VLS mechanism; i.e. $\mathrm{KCl}$ vapor pressure of and a temperature close to the melting point ${ }^{166}$.

The composition of the build-ups has been further investigated by Saint-Jane et al. ${ }^{162}$, using Xray fluorescence (XRF), scanning electron microscopy (SEM), and chloride potentiometric titration. Based on the analyses, it was found that the corrosion scale contained water-insoluble as well as water-soluble $\mathrm{Cl}$. Build-ups on the walls of cyclones, and the riser duct, contained substantial amounts of $\mathrm{Cl}$ in water-insoluble form, identified as chlorellestadite $\left(\mathrm{Ca}_{10}\left(\mathrm{SiO}_{4}\right)_{3}\left(\mathrm{SO}_{4}\right)_{3} \mathrm{Cl}_{2}\right)$, instead of the more common water-soluble $\mathrm{KCl}$ and $\mathrm{NaCl}$. The chlorellestadite formation might lead to the clogging of pipes, which results in a decreased clinker output, and necessitate cleaning. Based on thermodynamic calculations ${ }^{162}$, it was proposed that the chlorellestadite was formed due to the presence of gaseous $\mathrm{HCl}$, and reaction (8) which becomes more favored, as the temperature decreases. Consequently, the presence of chlorellestadite indicates formation of $\mathrm{HCl}$ in the hot atmosphere ${ }^{162}$.

The influence of $\mathrm{HCl}$ formation has been explained by the degree of contact between the gas and lime-containing dust ${ }^{162}$. Saint-Jane et al. ${ }^{162}$ proposed two reactions, (16) and (17), which can take place in the cooler parts of the kiln depending on the extent of contact of the gases with lime-containing dust ${ }^{167}$.

Insufficient dust contact;

$\mathrm{SO}_{2}(g)+2 \mathrm{KCl}(\mathrm{g})+\mathrm{H}_{2} \mathrm{O}(\mathrm{g})+\frac{1}{2} \mathrm{O}_{2}(g) \rightleftarrows \mathrm{K}_{2} \mathrm{SO}_{4}(\mathrm{l})+2 \mathrm{HCl}(\mathrm{g})$

Sufficient dust contact;

$$
\mathrm{SO}_{2}(g)+2 \mathrm{KCl}(g)+\mathrm{CaO}(s)+\frac{1}{2} \mathrm{O}_{2}(g) \rightleftarrows \mathrm{CaSO}_{4}(s)+2 \mathrm{KCl}(g)
$$


Poor contact between the hot kiln gases and the lime-containing dust in the kiln may cause formation of $\mathrm{HCl}$ from reaction of $\mathrm{KCl}$ with $\mathrm{SO}_{2}$. Subsequently, $\mathrm{HCl}$ in contact with the hot meal in the preheater unit can form chlorellestadite ${ }^{167}$. Figure 15 and Figure 16 illustrate the global equilibrium analyses simulating the reactions with sufficient and insufficient contact with limecontaining dust, respectively. The system was modeled as an enclosed box of variable volume with a fixed pressure of $1 \mathrm{~atm}$, considering two phases: a pure solid (chlorides and sulfates) and an ideal gas $\left(\mathrm{N}_{2}, \mathrm{CO}_{2}, \mathrm{O}_{2}\right.$ and $\mathrm{H}_{2} \mathrm{O}$ ). A third phase, which consisted on $\mathrm{CaO}$ (s) representing the dust, was only included for the case of the sufficient contact with lime containing dust (Figure $15)$.

The results show the effect of decreasing temperature (from 1400 to $1000^{\circ} \mathrm{C}$, corresponding to the kiln gas from the transition zone to the inlet of the rotary kiln). At high temperature, $\mathrm{SO}_{2}$ is favored due to the thermal decomposition in the burning zone for both cases. For the case of sufficient contact with dust, the $\mathrm{SO}_{2}$ concentration decreases to zero below $1200^{\circ} \mathrm{C}$ because it is captured by the lime-containing dust. In addition, no $\mathrm{HCl}$ in the gas phase is observed. On the contrary, for the case of insufficient contact with dust, not all the $\mathrm{SO}_{2}$ in gas phase is absorbed by $\mathrm{CaO}$ as the temperature decreases, and below $1200^{\circ} \mathrm{C}$, formation of alkali sulfates and $\mathrm{HCl}$ occurs. Figure 16 (insufficient contact with dust) indicates that $\mathrm{SO}_{2}$ and $\mathrm{HCl}$ in the gas phase will be observed in the kiln inlet. Saint-Jean et al. ${ }^{162}$ concluded that the $\mathrm{HCl}$ concentration can be reduced by means of better gas-solid contact in the kiln.

Sulfur- and Cl-concentrations in the hot meal can be used to evaluate the risk of build-up formation in the calciner, according to Figure $17^{168}$. The diagram is based on industrial experience, and is divided in 3 zones: low, medium and strong build-up tendency. The build-up tendency is linked to the required cleaning or removal of the build-ups. Therefore, it is 
recommended to operate a cement plant in the low and medium build-up tendency zones. According to Figure 17, the hot meal content of $\mathrm{SO}_{3}$ should be maintained below 6 wt. \%, and the $\mathrm{Cl}$-content below $3.5 \mathrm{wt} . \%$, in order to avoid strong build-up tendency.

It is generally accepted, and in agreement with

Table 6, that the formation of build-ups in the lower cyclones may be associated with an increase in chlorine evaporation, and the build-ups in the riser duct with an increase in Sevaporation.

\subsection{Coating and Ring Formation in Rotary Kilns}

Blockages in the rotary kiln are normally referred to, as either coating or ring formation, consisting of a mass of clinker or dust that adheres to the wall of the kiln and solidifies. They are easily formed, when an excess of $\mathrm{S}$ over alkalis exists in the kiln atmosphere. The kiln rings differ based on their composition and location in the kiln ${ }^{169-173}$. Figure 18 illustrates a rotary kiln with five typical complications, which are:

1. Nose rings or ash rings.

2. Clinker coating.

3. Trumpet coating or sinter ring.

4. Clinker rings or middle rings.

5. Transition zone rings

The nose ring, which is marked by point 1 in Figure 18, is formed in the hot burning zone, where the clinker leaves. It can be formed very rapidly, and sometimes needs daily removal. These formations are caused by crystallization of clinker liquid, or free alkali-sulfates in the 
clinker. The liquid present at the kiln nose permits adherence of the dust particles, and therefore the building of the nose ring continues. Microscopic analyses of clinker produced during the presence of a nose ring indicate the occurrence of slow cooling. Slowly cooled clinker causes the alite to revert back to belite and free lime ${ }^{170}$.

The build-up in the clinker cooler back wall, referred as snowman build-up, is illustrated in Figure 19. It is caused by the same problem that promotes the nose ring, i.e., a slow cooling of the clinker. The influence of granulometric characteristics of the raw materials to the formation of this coating has been investigated in an industrial cement plant by using quantitative analytical techniques and some measures to counteract this problem were suggested by Katsioti ${ }^{171}$.

Point 2 in Figure 18 shows the clinker coating, which normally has the same chemistry and mineralogy as the clinker charge, since it is made up of the clinker. It is desired to operate the kiln with coating formation to protect the lining from thermal shocks, abrasion by the kiln bed, and chemical infiltration by the gases, and to prolong the lifetime of the kiln ${ }^{172}$. The thickness of the coating is under normal conditions determined by the heat transfer through the lining which means that when the surface temperature of the lining reaches the melting point of the clinker liquid, it stops growing in thickness. Thus, an equilibrium exists at these conditions. Figure 20 shows the influence of the temperature on the coating in the rotary kiln. In scenario A, the rotary kiln has a thick coating layer that may continue to grow in thickness until the equilibrium temperature is reached. Scenario C shows a kiln with a hot flame. Here, the coating layer is seen to become liquefied and drop off of the refractory lining. If the thickness of the coating layer becomes too low, it will decrease the refractory lifetime. The surface temperature is the most important factor in the formation of a coating. Since the flame shape governs the surface temperature at all points in the burning zone, the flame has a considerable effect on the coating 
formation ${ }^{169}$. The amount and the properties of the liquid phase will also affect the ability to form the coating ${ }^{172}$.

Point 3 of Figure 18, marks the position in the rotary kiln, where the burning zone starts. The coating composition is similar to the clinker, because this coating is established where the liquid phase begins to form, but the melt comes into contact with a cooler surface and solidifies, thereby binding clinker particles together ${ }^{34}$. Changes in operational temperature can lead to coating formation at one location, which will later come off, when the temperature is changed. Repetitive shedding of coatings and formation of too much coating may lead to ring formation $^{169}$.

Point 4 of Figure 18 shows the clinker rings that form inside the kiln. Clinker rings are characterized by their relatively high content of alite and aluminate. They are typically caused by recirculation of clinker dust in the combustion product gases from the main burner. These rings can be avoided by eliminating the dust recirculation from the cooler or by adjustment of the main burner to produce a short and dense flame ${ }^{172}$.

The rings in the kiln inlet zone, called transition zone rings, are showed by Point 5 of Figure 18. These rings do not contain aluminate, and only very little alite ${ }^{173}$. The composition of transition zone rings is often quite complex, and it is associated with operating conditions, such as high concentrations of alkali chlorides in the kiln gas, or reducing condition in the bed material.

Reducing conditions, raw meal with low reactivity, flame shape, and burner position are known to increase the amount of $\mathrm{S}$ in the kiln atmosphere, thereby favoring ring formation ${ }^{163}$. Sulfospurrite, $\left(2 \mathrm{CaO} \cdot \mathrm{SiO}_{2}\right)_{2} \cdot \mathrm{CaSO}_{4}$, appears to be the mineral phase responsible for ring formation in the cement preheater kilns ${ }^{163}$. Sulfospurrite crystals have been found on the surface 
of the refractory lining, and subsequent rapid growth of the ring, in a $\mathrm{SO}_{3}$ rich kiln atmosphere, is probably enhanced by the liquid double sulfate $2 \mathrm{CaSO}_{4} \cdot \mathrm{K}_{2} \mathrm{SO}_{4}$ (Ca-langbeinite), which can be formed in a wide range of $\mathrm{K}_{2} \mathrm{SO}_{4}$ and $\mathrm{CaSO}_{4}$ compositions and temperatures, as shown in the corresponding phase diagram in Figure 21. The analyzed samples showed an internal variability, which reflected the variations in composition and temperature of the kiln gases ${ }^{164}$. The same study tested different refractory materials against ring formation, and concluded that $\mathrm{SiO}^{2-}$ impregnated alumina bricks impeded sulfospurrite crystallization by stabilizing belite very efficiently.

Kiln rings in a preheater kiln system are not as frequent as in previous kiln systems due to the improvements in manufacturing technology, operation control, and raw materials and clinker homogeneity ${ }^{175}$. These improvements have also resulted in significantly enhanced product performance. The operation process parameters experience nowadays less variation. This is illustrated in Figure 22, showing the variation of lime saturation factor (LSF) for three different rotary kilns. $\mathrm{LSF}$ is the ratio of $\mathrm{CaO}$ to the other three main oxides, and it controls the ratio of alite to belite in the clinker. The clinker produced in batches in bottle kilns in the nineteenth century was very heterogeneous as the raw materials. The oldest kiln from 1890, presents a big variation of the LSF percentage in short periods of time, and this large variability was causing operational problems, because the clinker was produced in batches in bottle kilns were very heterogeneous as well as the raw materials. The introduction of rotary kilns facilitated the blending and uniformity of the raw materials. In the long kiln, where calcination was taking place inside the rotary kiln, the process parameters showed still significant variation, but the variability has been significantly reduced for the actual preheater kilns, which show the 
improvement on operational control. For that reason, kiln rings are rarely formed in the actual preheater kiln systems.

\subsection{Shell Corrosion and Refractory Deterioration}

The combined presence of $\mathrm{SO}_{2}$ and $\mathrm{HCl}$ makes the kiln gas very corrosive ${ }^{151}$. Consequently, the presence of a local reducing atmosphere coupled with a high S-level in the kiln system may lead to refractory deterioration and corrosion of rotary kiln shells and calciner shells, which subsequently result in high maintenance costs.

Kiln shell corrosion in 12 suspension calciner kilns was studied by Jøns and Østergaard ${ }^{151}$. They found that the corrosion was restricted to a short zone, located from the start of the kiln coating to 10-20 $\mathrm{m}$ in the direction of the kiln inlet. Severe corrosion occurred when the kiln gas contained high levels of both $\mathrm{S}$ and $\mathrm{Cl}$. The corrosion products were found to be brittle and porous, with chlorides and alkali metals present in different amounts and homogenously distributed. Table 7 lists the chemical composition of the corrosion sample at distances of $48.5 \mathrm{~m}$ and $53 \mathrm{~m}$ from the kiln inlet. However, it was not possible to link the composition of the corrosion product to the position where the sample was taken. The corrosion reactions on the kiln shell are proposed to be chain reactions ${ }^{151,176}$. First, the release of $\mathrm{HCl}$ to the gas phase takes place by reactions (13) and (18) at temperatures higher than $900^{\circ} \mathrm{C}$ in the kiln, where thermally unstable alkali chlorides are transformed to more stable alkali sulfates. Hydrochloric acid can penetrate through the refractory, and due to the decrease in temperature, chlorine formation proceeds via reaction (19) at temperatures lower than $400^{\circ} \mathrm{C}^{151}$. According to Jøns and Østergård ${ }^{151}$, a temperature gradient, which is established by the lining and the porous deposit, will be formed between the kiln atmosphere and the kiln shell. The elemental chlorine can chemically interact with the metal shell by chlorination of iron, reaction (20). Subsequently, the 
oxidation of $\mathrm{FeCl}_{2}$, the hydrolysis of $\mathrm{FeCl}_{3}$, and sulfidation of iron continue by reactions (21), (22), and (23), respectively.

$$
\begin{aligned}
& 2 \mathrm{KCl}(g)+\mathrm{SO}_{2}(g)+1 / 2 \mathrm{O}_{2}(g)+\mathrm{H}_{2} \mathrm{O}(g) \rightarrow \mathrm{K}_{2} \mathrm{SO}_{4}(g)+2 \mathrm{HCl}(g) \\
& 2 \mathrm{HCl}(g)+1 / 2 \mathrm{O}_{2}(g) \rightarrow \mathrm{Cl}_{2}(g)+\mathrm{H}_{2} \mathrm{O}(\mathrm{g} / \mathrm{l}) \\
& \mathrm{Cl}_{2}(\mathrm{~g})+\mathrm{Fe}(\mathrm{s}) \rightarrow \mathrm{FeCl}_{2}(\mathrm{~s}) \\
& 12 \mathrm{FeCl}_{2}(\mathrm{~s})+\mathrm{O}_{2}(\mathrm{~g}) \rightarrow 8 \mathrm{FeS}_{3}(\mathrm{~g} / \mathrm{l})+2 \mathrm{Fe}_{2} \mathrm{O}_{3}(\mathrm{~s}) \\
& \mathrm{FeCl}_{3}(\mathrm{~s})+3 \mathrm{H}_{2} \mathrm{O}(\mathrm{g} / \mathrm{l}) \rightarrow 3 \mathrm{HCl}(\mathrm{g})+\mathrm{Fe}(\mathrm{OH})_{3}(\mathrm{~s} / \mathrm{l}) \\
& 4 \mathrm{Fe}(\mathrm{s})+\mathrm{SO}_{2}(\mathrm{~g}) \rightarrow \mathrm{FeS}_{2}(\mathrm{~s})+\mathrm{Fe}_{3} \mathrm{O}_{4}(\mathrm{~s})
\end{aligned}
$$

The gaseous chlorine is believed to be the main promoter of corrosion since it increases the porosity of the corrosion layer, thus decreasing the diffusion resistance, and thereby making the kiln more vulnerable to further attacks ${ }^{151}$. A schematic representation of the shell corrosion is presented in Figure 23. It shows the different compounds that may be formed in the shell plate causing corrosion. Two types of corrosion are observed: ${ }^{1)}$ corrosion during kiln operation resulting in scaling of the kiln shell; this is the oxidation of the metallic iron by dry gases (containing $\mathrm{S}$ and/or $\mathrm{Cl}$ ) at elevated temperatures, also known as high temperature corrosion; and ${ }^{2)}$ rusting during kiln shut-downs caused by condensation or absorption of moisture.

Experiences from different plants have revealed that in the absence of chlorides, the corrosion rate stays at an acceptable level, i.e., $1 / 3 \mathrm{~mm}$ per year ${ }^{178}$. The corrosion rate has been calculated for the thinnest part of the kiln shell, which limits the lifetime of the kiln shell. Assuming a thickness of $25 \mathrm{~mm}$ for the thin part, this kiln shell can be worn down by corrosion to $12 \mathrm{~mm}$ before the stresses become too high, and the thinning takes between 30 to 40 years ${ }^{179}$.

The calciner corrosion is believed to be caused by an increased S-circulation, which penetrates into the refractory material. Sulfur compounds may react with moisture and form $\mathrm{H}_{2} \mathrm{SO}_{4}$ which 
condenses on the inner steel shell ${ }^{168}$. Figure 24 illustrates schematically the mechanism of corrosion due to the infiltration of corrosive gases, such as $\mathrm{SO}_{2}$ and $\mathrm{HCl}$, through the pore structure of the refractory lining or through joints penetrating the outside steel shell ${ }^{180}$.

\section{Circulation of Volatile Elements due to Combustion of Alternative Fuels}

Alternative fuels have different characteristics compared to fossil fuels. Their utilization in the cement manufacturing may therefore have several effects on the process stability, such as local reducing conditions, poor heat distribution, unstable pre-calciner operation, blockages in the preheater cyclones, build-ups in the kiln riser ducts, higher $\mathrm{SO}_{2}, \mathrm{NO}_{\mathrm{x}}$ and $\mathrm{CO}$ emissions, and dusty kilns ${ }^{21}$. Furthermore, the type of fuel used may introduce specific material components or increase the concentration of specific elements, which can interfere with the chemistry/quality of the cement, refractory life, gas and material flow or potential emissions to the atmosphere, and thereby affect the operation of the system.

\subsection{Introduction or Increase of Inorganic Elements in the Cement Chemistry}

The main elements introduced with alternative fuels are: $\mathrm{Na}, \mathrm{K}, \mathrm{S}, \mathrm{Cl}, \mathrm{Zn}, \mathrm{P}, \mathrm{Fe}$, Si found as $\mathrm{SiO}_{2}$, and carbon in cases of incomplete combustion. Furthermore, heavy metals such as As, $\mathrm{Cd}$, $\mathrm{Cr}, \mathrm{Pb}, \mathrm{Hg}, \mathrm{Cu}, \mathrm{Ni}$, and $\mathrm{Sn}$ may be incorporated as traces. The presence of heavy metals in the clinker does not affect the quality when the amount is below a threshold limit. Trace elements exceeding the threshold limit may affect the clinker, e.g. Cu affects the alite formation, while $\mathrm{Zn}$ will affect aluminate ${ }^{181}$. However, presence of heavy metals is one of the major hazards in the flue gas from alternative fuels due to the environmental implications. Mercury and Cd are examples of heavy metals, which tend to be highly volatile ${ }^{182}$. 
Alternative fuels that contain Fe (e.g. TDF, up to 25 wt. $\%$ for truck tires ${ }^{21}$ ) or silica (e.g. ash from rice husks, which contain $70-90 \%$ silica $^{102}$ ) contribute to the main oxides of the clinker, and their required content in the raw materials should therefore be reduced.

The clinker quality may also be negatively affected, if the clinker is exposed to reducing conditions induced by the alternative fuel when combusted in direct contact with the material bed in the rotary kiln. The main problem is the reduction of $\mathrm{Fe}_{2} \mathrm{O}_{3}$ to $\mathrm{FeO}$, which takes place at temperatures higher than $450^{\circ} \mathrm{C}$, or to elemental $\mathrm{Fe}$, which occurs under strongly reducing conditions ${ }^{183}$. FeO, which has $\mathrm{Fe}$ in the oxidation state + II, catalyzes the decomposition of alite and reduces the ferrite content. This leads to modifications of the Portland cement properties, and potentially a color change, a phenomenon known as brown clinker ${ }^{183}$. The clinker quality may also be negatively affected by the addition of metal oxide residues ${ }^{184}$ and waste material ashes ${ }^{29,53,185,186}$ to the clinker during the clinkering process through combustion of alternative fuels if the raw meal composition is not adjusted accordingly.

\subsection{Local Reducing Conditions}

The kiln atmosphere is oxidizing in order to produce a good quality cement clinker and ensure a proper burn-out of the fuel ${ }^{11}$. However, when there is fuel spillage from the calciner and/or main burner, and/or fuel are fired into the rotary kiln material inlet, it can deplete oxygen locally and thereby cause local reducing conditions that may have a negative effect on the clinker quality and the process stability. Local reducing conditions in the kiln bed affect the melt phase composition and viscosity and thereby the nodulation process. More information can be found elsewhere ${ }^{187,188}$. Only the effects on the process stability are considered here. It should be 
emphasized that reducing conditions in the kiln bed material do not necessarily mean reducing conditions in the gas phase and vice versa.

The process stability is mainly affected by the increase in S-release from the raw meal to the gas phase. The decomposition of $\mathrm{CaSO}_{4}$ is promoted by reducing agents released as volatiles by the fuels, i.e., $\mathrm{CO}, \mathrm{CH}_{4}$ and $\mathrm{H}_{2}$, released by the fuels, so-called reductive decomposition of $\mathrm{CaSO}_{4}$. The fundamentals of the reductive decomposition of $\mathrm{CaSO}_{4}$ of mainly $\mathrm{CO}$ have been studied over a wide range of conditions in relation to chemical-looping combustion ${ }^{189-199}$. However, it is difficult to link these studies with the conditions of the rotary kiln, because the reducing gases will be in contact with the bed material, creating locally reducing conditions, while the flue gas will not experience the reducing conditions, since it is rich in oxygen.

The reductive decomposition of $\mathrm{CaSO}_{4}$ by $\mathrm{CO}$ is described as follows, where depending on the reducing potential $\left(\mathrm{P}_{\mathrm{CO}} / \mathrm{P}_{\mathrm{CO} 2}\right)$ and the temperature one or the other reaction is favored.

$$
\begin{aligned}
& \mathrm{CaSO}_{4}(\mathrm{~s})+\mathrm{CO}(\mathrm{g}) \rightarrow \mathrm{CaO}(\mathrm{s})+\mathrm{SO}_{2}(g)+\mathrm{CO}_{2}(g) \\
& \mathrm{CaSO}_{4}(\mathrm{~s})+4 \mathrm{CO}(\mathrm{g}) \rightarrow \mathrm{CaS}(\mathrm{s})+4 \mathrm{CO}_{2}(g)
\end{aligned}
$$

The favored reactions over $900^{\circ} \mathrm{C}$ involving $\mathrm{H}_{2}$ and $\mathrm{CH}_{4}$ are reactions (26) and (27). However, competing reactions exist, promoting formation of $\mathrm{CaO}$ and release of $\mathrm{SO}_{2}$ or $\mathrm{H}_{2} \mathrm{~S}$, see further details for $\mathrm{H}_{2}$ in references ${ }^{196}$ and $\mathrm{CH}_{4}$ in references ${ }^{198,199}$.

$$
\begin{aligned}
& \mathrm{CaSO}_{4}(\mathrm{~s})+4 \mathrm{H}_{2}(g) \rightarrow \mathrm{CaS}(\mathrm{s})+4 \mathrm{H}_{2} \mathrm{O}(\mathrm{g}) \\
& \mathrm{CaSO}_{4}(\mathrm{~s})+\mathrm{CH}_{4}(\mathrm{~g}) \rightarrow \mathrm{CaS}(\mathrm{s})+\mathrm{CO}_{2}(g)+2 \mathrm{H}_{2} \mathrm{O}(\mathrm{g})
\end{aligned}
$$

Since the overall gas atmosphere is oxidizing, reaction (28) can occur, releasing $\mathrm{SO}_{2}$. Thereby, reducing conditions promote $\mathrm{SO}_{2}$ release and tend to alter considerably and increase the intensity of the S-cycle in the kiln system causing operational problems. 
$\mathrm{CaS}(\mathrm{s})+\frac{3}{2} \mathrm{O}_{2}(g) \rightarrow \mathrm{CaO}(s)+\mathrm{SO}_{2}(g)$

Alkali sulfate is not expected to decompose by reducing agents when $\mathrm{CaSO}_{4}$ is present, because these compounds are thermally more stable than $\mathrm{CaSO}_{4}{ }^{200}$. However, no investigations have been conducted using alkali sulfates or the combination of three sulfates under reducing conditions.

\subsection{Increase of Circulation Phenomena in the Kiln System}

As described, $\mathrm{S}$ and $\mathrm{Cl}$ circulation may be enhanced due to the utilization of alternative fuels. High concentrations of these compounds often cause difficulties in kiln operation with build-ups, mainly in the preheater and the kiln inlet section. The intensity of the cycles varies between different systems, and there are also considerable variations within one single kiln system, depending on the operating conditions.

\subsubsection{Sulfur Circulation}

Incomplete combustion of fuels, when they are burned in direct contact with the bed material, can cause an increase of S-circulation because fuel volatiles, acting as reducing agents to promote the reductive decomposition of $\mathrm{CaSO}_{4}$, are present in higher concentrations during the combustion in an oxygen-lean environment. Normally, the increase of S-circulation is associated to use of alternative fuels due to their different physical and chemical properties compared to fossil fuels, which are finely grinded and combusted fully in the calciner or in the main burner. However, an increase of S-circulation has been reported when unburned petcoke was admitted to the kiln inlet ${ }^{106}$. 
In a laboratory scale horizontal tube reactor the release of $\mathrm{SO}_{2}$ from a synthetic cement calcined raw material containing $\mathrm{CaSO}_{4}$ as sulfur source was quantified as a function of gas atmosphere, alternating oxidizing and reducing conditions with $\mathrm{CO}, \mathrm{H}_{2}$ and $\mathrm{CH}_{4}$ in the temperature range from 900 to $1100^{\circ} \mathrm{C}^{133}$. This temperature range corresponds to the bed temperature interval in the material inlet of an industrial rotary kiln. The alternating oxidizing and reducing conditions were applied in intervals of 2 minutes and were repeated over 20 minutes. Figure 25 shows the results of sulfur release under the alternating oxidizing and reducing conditions using different reducing agents.

The results with $\mathrm{CO}$ showed an increase in sulfur release as function of temperature. The sulfur release due to reaction with $\mathrm{H}_{2}$ or $\mathrm{CH}_{4}$ increased from 900 to $1000{ }^{\circ} \mathrm{C}$ but decreased at $1100{ }^{\circ} \mathrm{C}$. However, the experiments suffered from mass transfer limitations between the solid material and gas, and the gas analysis system failed to detect $\mathrm{H}_{2} \mathrm{~S}$, which most probably was formed under the reducing conditions with $\mathrm{H}_{2}$ and $\mathrm{CH}_{4}$. Sulfur mass balances for the experiments were not checked and therefore the effect of the reducing agent on sulfur release was not quantified. This results were compared the results with Hansen's findings where no reductive decomposition was obtained with $\mathrm{CH}_{4}{ }^{116}$. However, the reaction conditions were quite different in two experimental investigations, so no direct parallels could be drawn.

Sulfur release from the cement raw materials during combustion of solid fuels has been scarcely studied. Experiments in pilot-scale simulating the kiln inlet conditions were performed by Nielsen et al. ${ }^{201}$ They studied the effect of energy input, fuel type, temperature, and bulk oxygen concentration on sulfur release in combustion of alternative fuels (sewage sludge, petcoke, saw dust, tire granulate, polypropylene flakes, tire rubber cylinders, and pine wood cubes; listed in increasing order of particle size). Figure 26 shows the total sulfur release as a 
function of energy input from different fuels at $900^{\circ} \mathrm{C}$. Increasing energy input leads to larger volatile release and thereby more strongly reducing conditions near the raw materials, resulting in higher sulfur release from the raw meal.

Figure 27 shows that the S-release from raw materials is insignificant at 700 and $800^{\circ} \mathrm{C}$, while at 900 and $1000^{\circ} \mathrm{C}$ it increases strongly for all fuels. Comparing the tire rubber and wood particles, granulate tire and saw dust give rise to higher S-release while the S-release is much smaller for the tire and wood particle, but it is not clear whether this is due to fuel composition, the conversion pathway, or the number of particles. Cortada Mut et al. ${ }^{202}$ studied experimentally the $\mathrm{SO}_{2}$ release from simulated cement raw materials at $900^{\circ} \mathrm{C}$ during combustion of pine wood and tire rubber, focusing on the influence of volatile content and fuel particle size. They used three different particle sizes ranging from 19 to $2 \mathrm{~mm}$ at identical energy inputs. It was found that the $\mathrm{SO}_{2}$ release rate, as well as the total $\mathrm{SO}_{2}$ release, from the cement raw materials increased with decreasing fuel particle size $\mathrm{e}^{202}$. This was ascribed to the increased heating rate, hence increased devolatilisation rate, of the smaller fuel particles, resulting in a higher volatile gas concentration for a shorter time interval than observed for larger fuel particles. Cortada Mut et al. find that the $\mathrm{SO}_{2}$ release from the cement raw materials mainly takes place during fuel devolatilization rather than during char oxidation ${ }^{202}$.

The effect of $\mathrm{O}_{2}$-concentration on S-release is shown in Figure 28. As expected, the S-release decreases with increasing $\mathrm{O}_{2}$-concentration, since oxygen reacts with the fuel volatiles and act to lower the concentration of the reducing agents.

The effect on the sulfur release of introducing the main reducing gases $\left(\mathrm{CO}, \mathrm{H}_{2}\right.$ and $\left.\mathrm{CH}_{4}\right)$ in controlled concentrations into the rolling bed in the high temperature rotary drum was investigated by Cortada Mut et al. ${ }^{202}$ at different temperatures, oxygen contents, and times of 
exposure. The experiments indicated that a threshold concentration for the reducing agents exists, below which $\mathrm{SO}_{2}$ release does not occur. Short pulses with high concentrations of reducing gas yielded higher $\mathrm{SO}_{2}$ release compared to long pulses with low concentrations of reducing gas ${ }^{202}$. Experiments with mixtures of reducing agents indicated interactions between the reducing gases, and the $\mathrm{SO}_{2}$ release could not be predicted by addition of the single contributions from the individual reducing gases ${ }^{202}$.

In an industrial cement plant burning pellets of dried sewage sludge through the main burner, the S-evaporation has a decreasing linear tendency with the $\mathrm{O}_{2}$-concentration at the kiln material inlet, see Figure 29. This is in line with the results shown in Figure 28. Increasing the $\mathrm{O}_{2}$-content at the kiln material inlet minimizes the S-evaporation because the oxygen in the freeboard atmosphere may oxidize the reducing agents. Thereby, the increase of oxygen concentration is believed to reduce the occurrence of local reducing condition in the clinker be where unburned sewage sludge were dropped from the flame ${ }^{47}$.

In the calciner, the fuel and the raw meal is in direct contact, but the $\mathrm{SO}_{2}$ release is not taking place there. It has been suggested that partly calcined hot meal is less problematic than completely calcined hot meal with regards to S-release, since the endothermic calcination reactions absorb the heat from fuel oxidation and thereby prevent the temperature increment that leads to S-release. In the calciner, sulfur release from fuel-S is possibly minimized, because the sulfur oxides react preferentially with $\mathrm{CaCO}_{3}$ forming $\mathrm{CaSO}_{4}{ }^{203}$. However, there is a lack of research in this area.

It is currently unknown how oxy-fuel combustion in the kiln system, used to optimize the alternative fuel combustion, influences the sulfur chemistry and hereby the sulfur circulation. This technology has been scarcely studied in relation to the cement industry and it is not 
commonly used in the cement industry due to its high $\cos ^{87}$. Studies of oxy-fuel combustion using alternative fuels have only focused on the substitution rate in the kiln, the increase of productivity and the stack emissions $\mathrm{s}^{20,21,40}$ but any influence on the volatile recirculation has not been evaluated. The changes in sulfur chemistry using pulverized S-containing coal under oxyfuel conditions in the power plant industry have been reported ${ }^{204-206}$, showing enhanced $\mathrm{SO}_{2}$ and $\mathrm{SO}_{3}$ concentrations due to recycling of $\mathrm{S}$ with the flue gas. However, in cement plants, oxy-fuel combustion may not involve recirculation of flue gas. Tests on a cement plant using alternative fuels and oxy-fuel combustion have shown that oxygen injection can enhance the combustion and reduce the emissions of $\mathrm{SO}_{\mathrm{x}}$ and $\mathrm{CO}^{207}$. The localized higher oxygen concentrations favors the retention of sulfur in the clinker, which may indicate a reduction of sulfur recirculation, and oxygen injection into the kiln has not shown any increase in stack emissions ${ }^{207}$. More investigations are needed to understand how the volatile elements may be affected when using the oxy-fuel combustion technology.

\subsubsection{Chlorine Circulation}

Alternative fuels, RDF in particular, may contain $\mathrm{Cl}$ in levels up to 4 wt. \%, as listed in 
Table 5. Waste plastics such as PVC, sewage sludge, meat and bone meal, and chlorinated hydrocarbons, may increase the amount of $\mathrm{Cl}$ introduced into the kiln system significantly ${ }^{208}$. The circulation of $\mathrm{Cl}$ is determined by the phase equilibrium between liquid and gaseous $\mathrm{KCl}$. The evaporation generally occurs in the burning zone of the kiln and the re-condensation in the riser pipes and lower cyclones, where $\mathrm{Cl}$ can combine with alkali and sulfate species and form mixtures with a low melting point. The degree of volatile recycling within the system will increase with increasing amounts of alkali chlorides. High $\mathrm{Cl}$ levels may influence the economy of clinker production by causing kiln stoppages, corrosion, and inhomogeneous uneven clinker quality.

Under unfavorable circumstances, some of the $\mathrm{Cl}$, which is normally present in the kiln atmosphere in the form of $\mathrm{NaCl}$ and $\mathrm{KCl}$, can be converted to $\mathrm{HCl}$. The $\mathrm{HCl}$ can cause corrosion of the steel walls of the rotary kiln ${ }^{162}$. A bypass can be a very effective way of removing chlorides from the kiln system. Approximately $90 \%$ of the chlorine can be removed by extracting $5 \%$ of kiln exhaust gas, but no more than $15 \%$ of the alkali or sulfur can be removed ${ }^{209}$.

The effects of $\mathrm{Cl}$ are strongly influenced by the S-load in the kiln. A model of the Clcirculation in the kiln and how this is influenced by the sulfur load based on simple thermodynamic considerations was developed by Jøns et al. ${ }^{147}$. The findings were supported by statistical treatment of data collected from more than 50 modern kiln systems. It was concluded 
that a higher sulfate content in clinker resulted in a lower chlorine evaporation factor, even though it was not a strong correlation.

\section{Conclusions}

Cement production is an energy intensive industry. There is interest in replacing fossil fuels by alternative fuels, which may account for up to $80 \%$ of the energy input today. The use of alternative fuels may lead to incomplete combustion, however, and can alter the input and the behavior of the inorganic volatile elements such as $\mathrm{S}, \mathrm{Cl}, \mathrm{K}$, and $\mathrm{Na}$ in the kiln system.

Sulfur, $\mathrm{Cl}, \mathrm{K}$, and $\mathrm{Na}$ are introduced in the kiln system by the raw meal and the fuels. The chlorine is mainly introduced by fuels, while alkali is provided by the raw materials. The compounds containing $\mathrm{S}, \mathrm{Cl}, \mathrm{K}$ and $\mathrm{Na}$ partly evaporate in the burning zone of the kiln and condense on the incoming raw meal in the cooler parts. By repetitive evaporation and condensation, these elements circulate in the cement plant at different temperatures and locations of a cement plant.

The S-circulation is the most complex. In the preheater, the organic sulfur is oxidized, which is followed by the sulfation of $\mathrm{CaO}$ with $\mathrm{SO}_{2} / \mathrm{SO}_{3}$ in the calciner where alkali sulfates can also be present. In the rotary kiln, a sulfate melt is formed and the evaporation of $\mathrm{S}$ takes place forming $\mathrm{SO}_{2}, \mathrm{~K}_{2} \mathrm{SO}_{4}$ and $\mathrm{Na}_{2} \mathrm{SO}_{4}$ in the gas phase in the burning zone. The volatilization of sulfur depends on the $\mathrm{Alk} / \mathrm{SO}_{3}$ ratio, and on the operating conditions such as $\mathrm{O}_{2}$-concentration and temperature.

The main compounds of the $\mathrm{Cl}$-circulation are $\mathrm{KCl}$ and $\mathrm{NaCl}$, which can be in solid, liquid or gas state depending on the temperature. The volatilization of $\mathrm{Cl}$ depends only on the burning 
zone temperature and the $\mathrm{Cl}$ evaporation factor is typically around 0.99 for the temperature found in a cement kiln.

Potassium and $\mathrm{Na}$ can be bound as sulfates, chlorides or carbonates, depending on the balance of sulfur and alkali. The volatility of $\mathrm{K}$ and $\mathrm{Na}$ depends greatly on how they are bound.

Special focus has been given to the circulation of sulfur because this cycle can be modified and/or increased by fuel spillage from the calciner and/or main burner, where the fuel combustion proceeds in contact with the bed material of the rotary kiln and causes local reducing conditions. Consequently this may have a negative effect on the clinker quality, and the process stability in term of build-ups formation and shell corrosion.

Build-ups in the lower cyclones and the riser pipe from different cement plants have been characterized analytically. Spurrite and $\mathrm{KCl}$ have been found to be responsible for the tendency of build-ups and the crystallization of $\mathrm{KCl}$ has been postulated to take place by a vapor-liquidsolid mechanism. The risk of formation of build-ups can be evaluated by the sulfur and chlorine content in the hot meal.

Insufficient contact between the hot kiln gases and lime-containing dust promotes the formation of gaseous $\mathrm{HCl}$. High concentrations of $\mathrm{SO}_{2}$ and $\mathrm{HCl}$ in presence of moisture makes the kiln gas very corrosive and can lead to corrosion of rotary kiln shells and calciner shells.

Local reducing conditions promote S-release in the kiln inlet due to decomposition of $\mathrm{CaSO}_{4}$ by reducing agents, such as $\mathrm{CO}, \mathrm{CH}_{4}$ and $\mathrm{H}_{2}$ released during devolatilization of the fuel. Experimental investigations on sulfur release during fuel combustion have shown that sulfur release increase with increasing temperature and energy input, and decreasing $\mathrm{O}_{2}$-concentration and particle size. However, there is a lack of understanding in this area. 


\section{ACKNOWLEDGMENT}

The work described in this article is part of a research platform on future cement technology

financed by The Danish National Advanced Technology Foundation, Technical University of Denmark (DTU) and FLSmidth A/S.

\section{SUPPORTING INFORMATION}

This information is available free of charge via the Internet at http://pubs.acs.org/. 


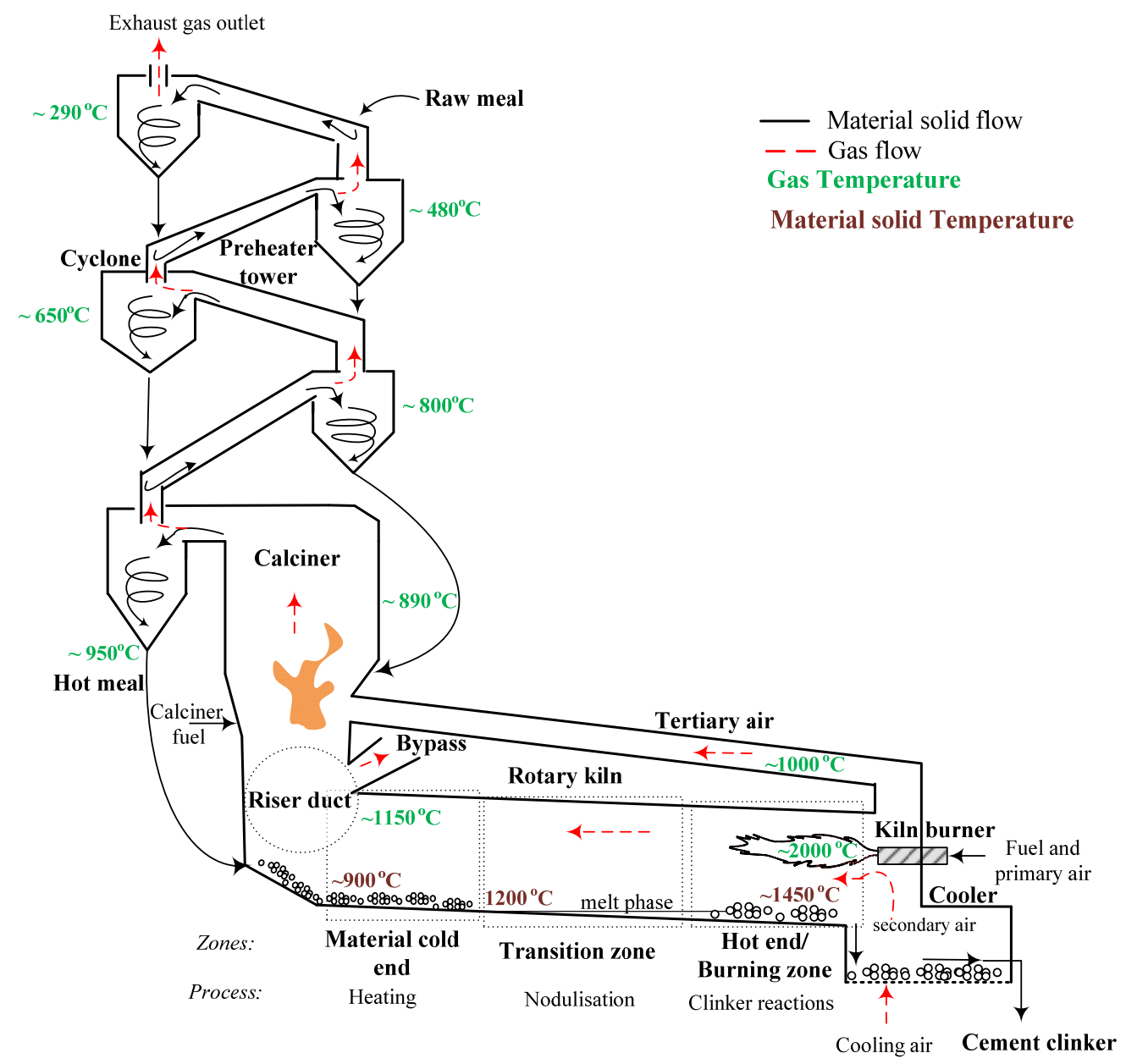

Figure 1. Scheme of a typical modern kiln system and their parts, inspired by FLSmidth ${ }^{17}$.

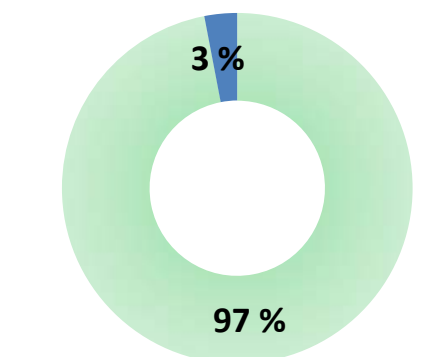

= Fossil fuel $\quad$ Alternative fuel

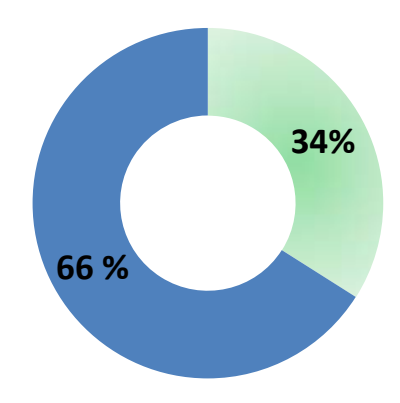

Fossil fuel $\quad$ Alternative fuel

Figure 2. Percentage of fossil fuels and Figure 3. Percentage of fossil fuels and 


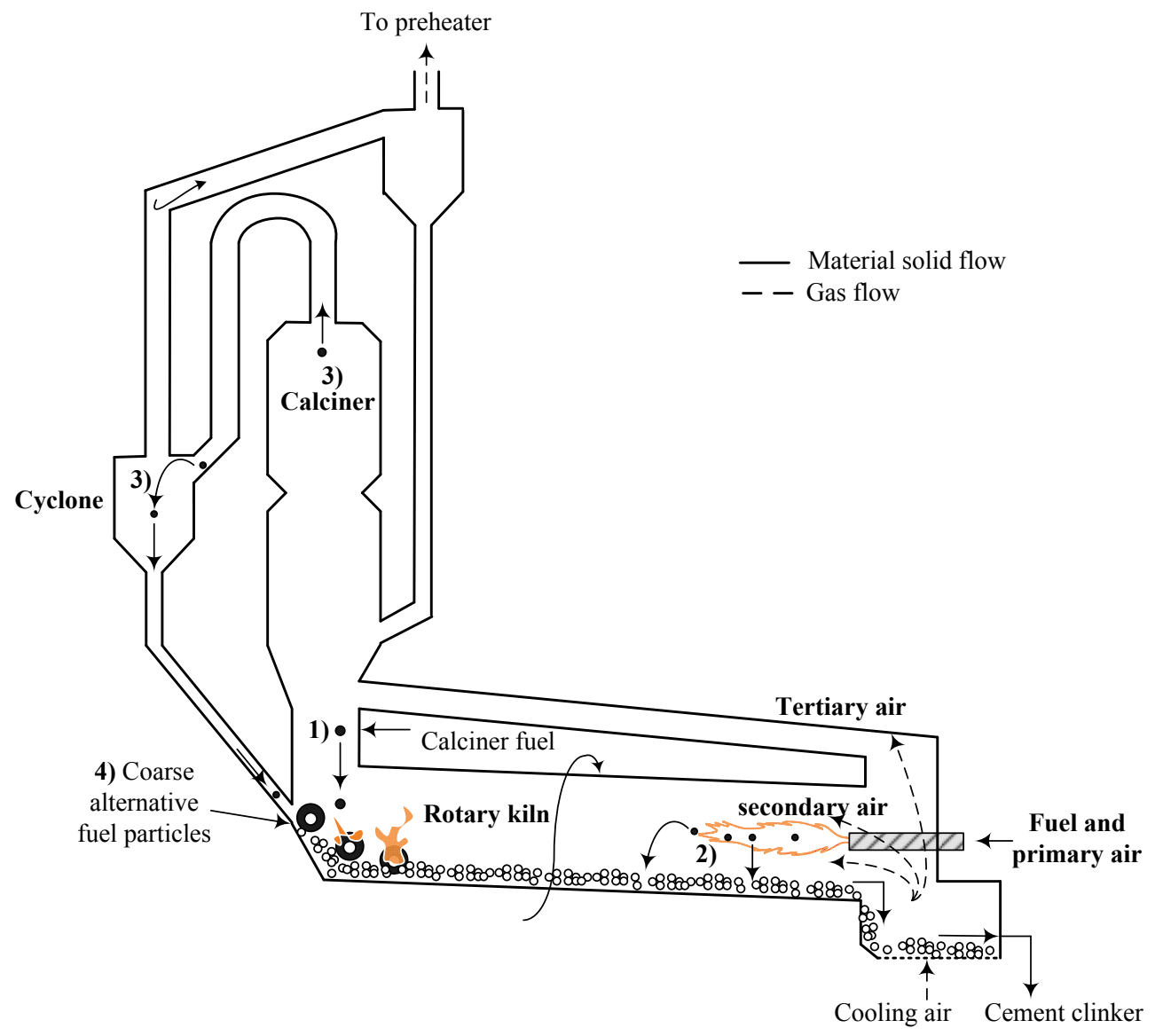

Figure 4. Illustrative scheme of the four scenarios, whereby solid fuels can drop into the material charge in the rotary kiln, adapted from Nielsen ${ }^{21}$. 


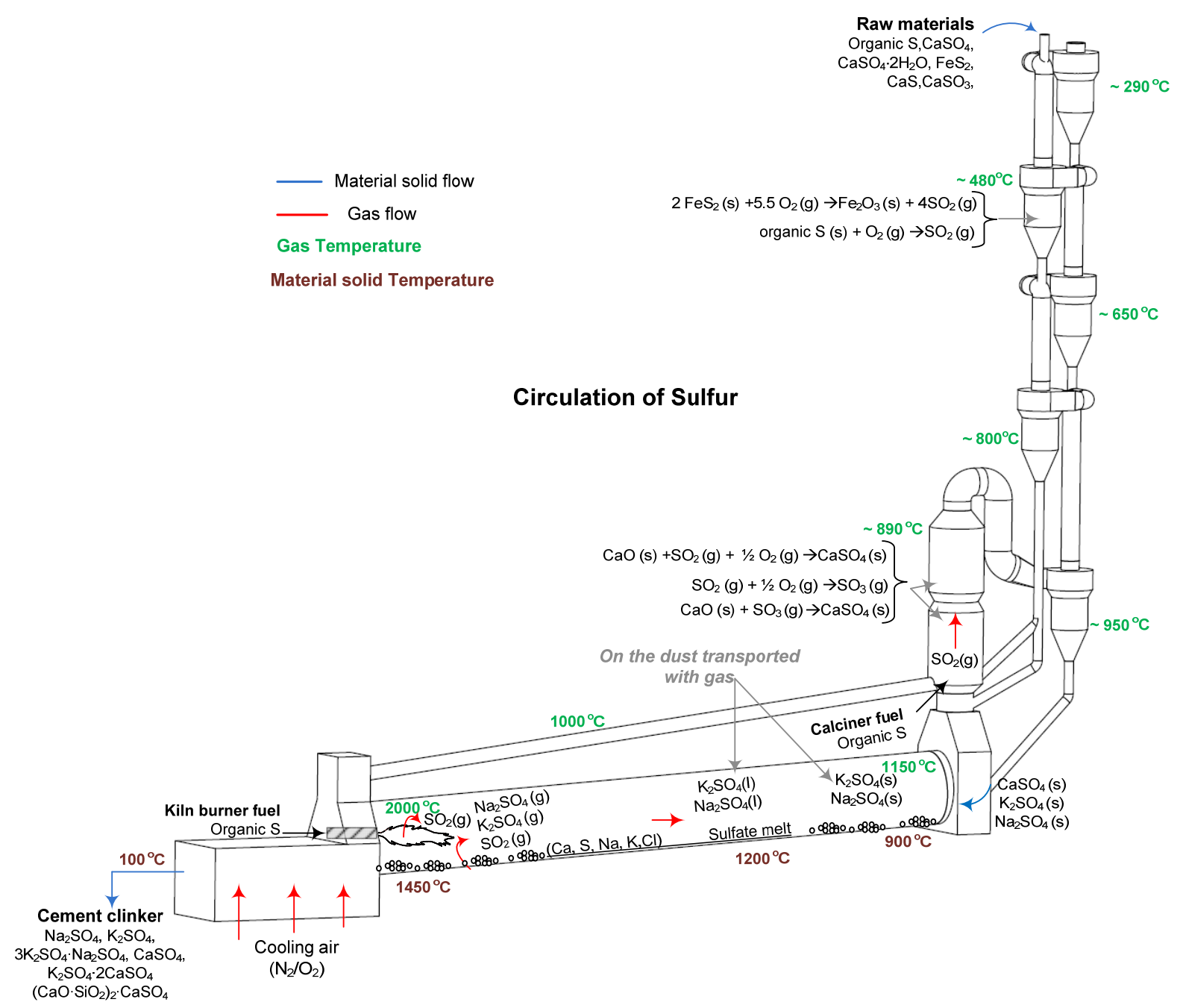

Figure 5. Circulation of the sulfur compounds in the kiln system. 


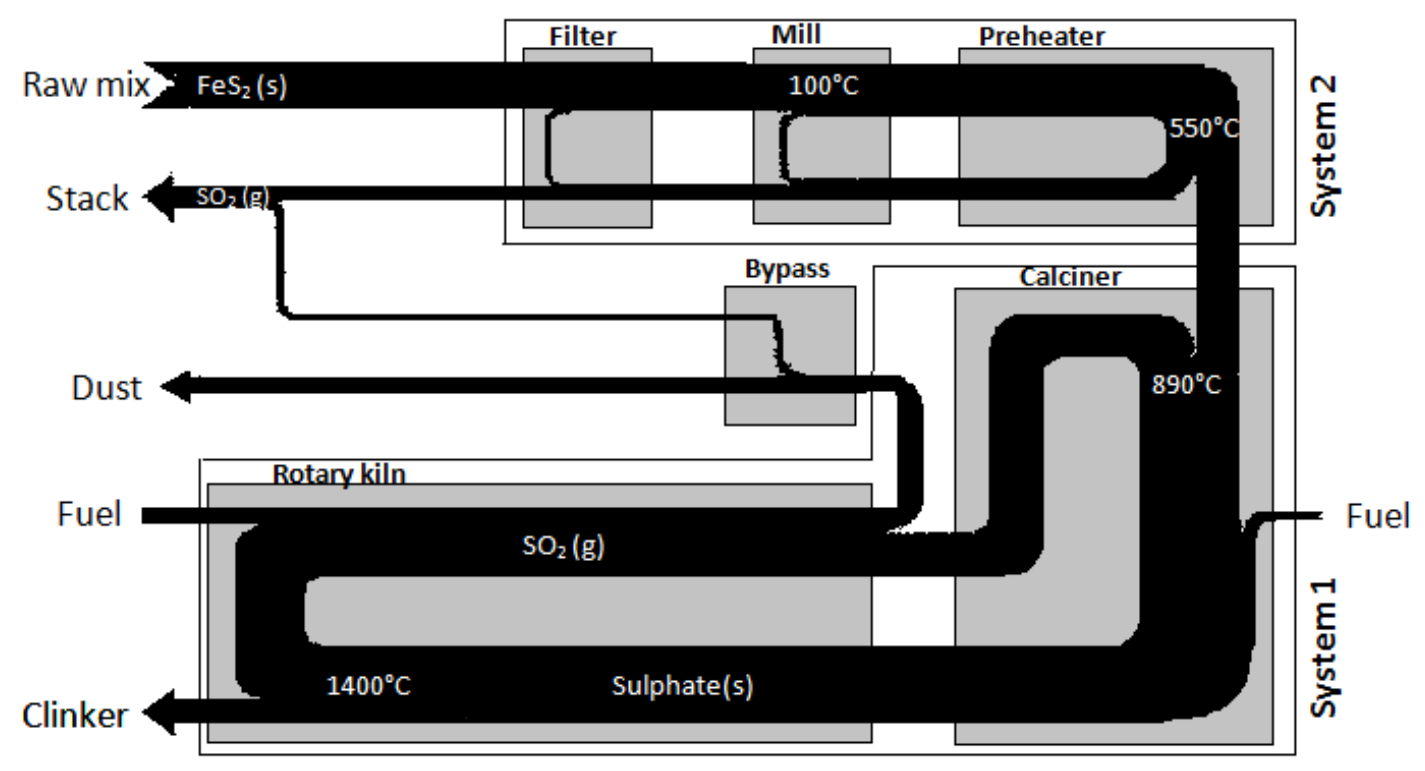

Figure 6. Sankey diagram of the sulfur circulation in a cement plant operating by the dry method. Raw meal and fuel are sulfur contributors and the sulfur leaves as emissions, in the dust or embedded in the clinker. The thickness of the lines indicates relative flow rates, adapted of Nielsen and Jespsen ${ }^{106}$. 


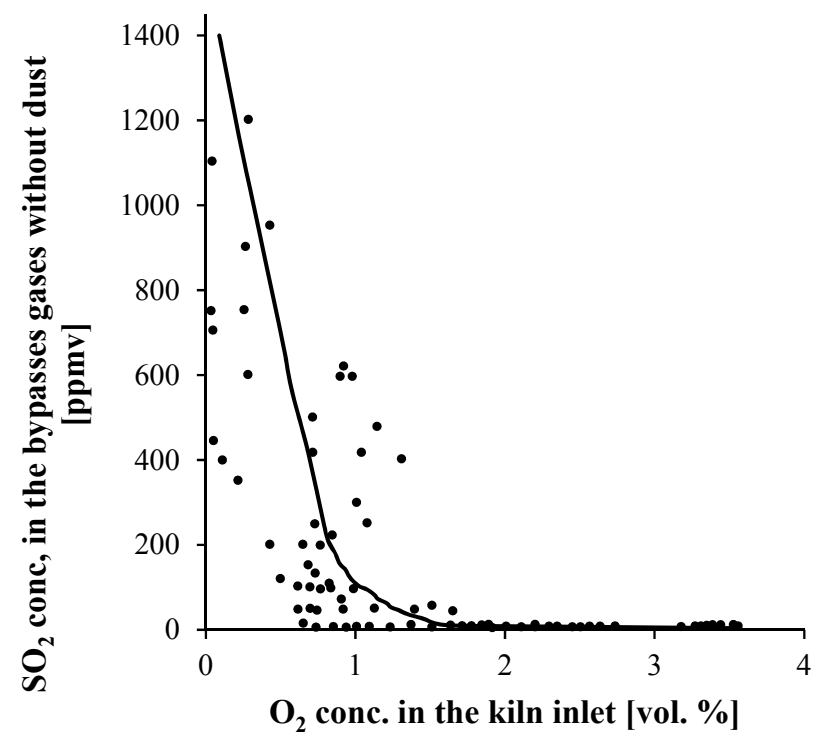

Figure 7. Relationship between $\mathrm{SO}_{2}$ bypass emissions and $\mathrm{O}_{2}$ concentration in the inlet of the rotary kiln, adapted from Steuch and Johansen ${ }^{135}$. 


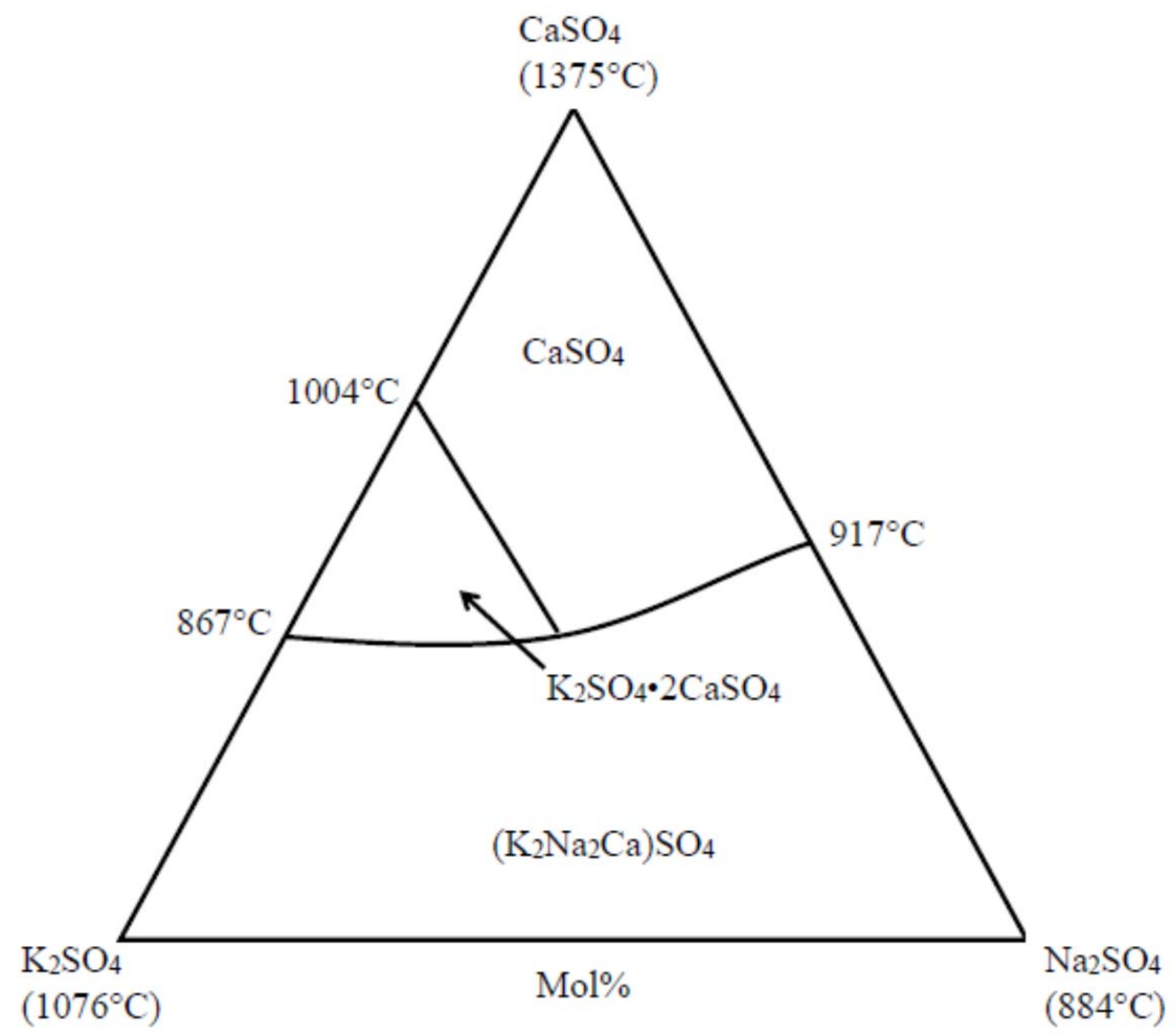

Figure 8. Tertiary phase diagram for $\mathrm{CaSO}_{4}, \mathrm{~K}_{2} \mathrm{SO}_{4}$ and $\mathrm{Na}_{2} \mathrm{SO}_{4}$, adapted from Rowe et al. ${ }^{137}$. 


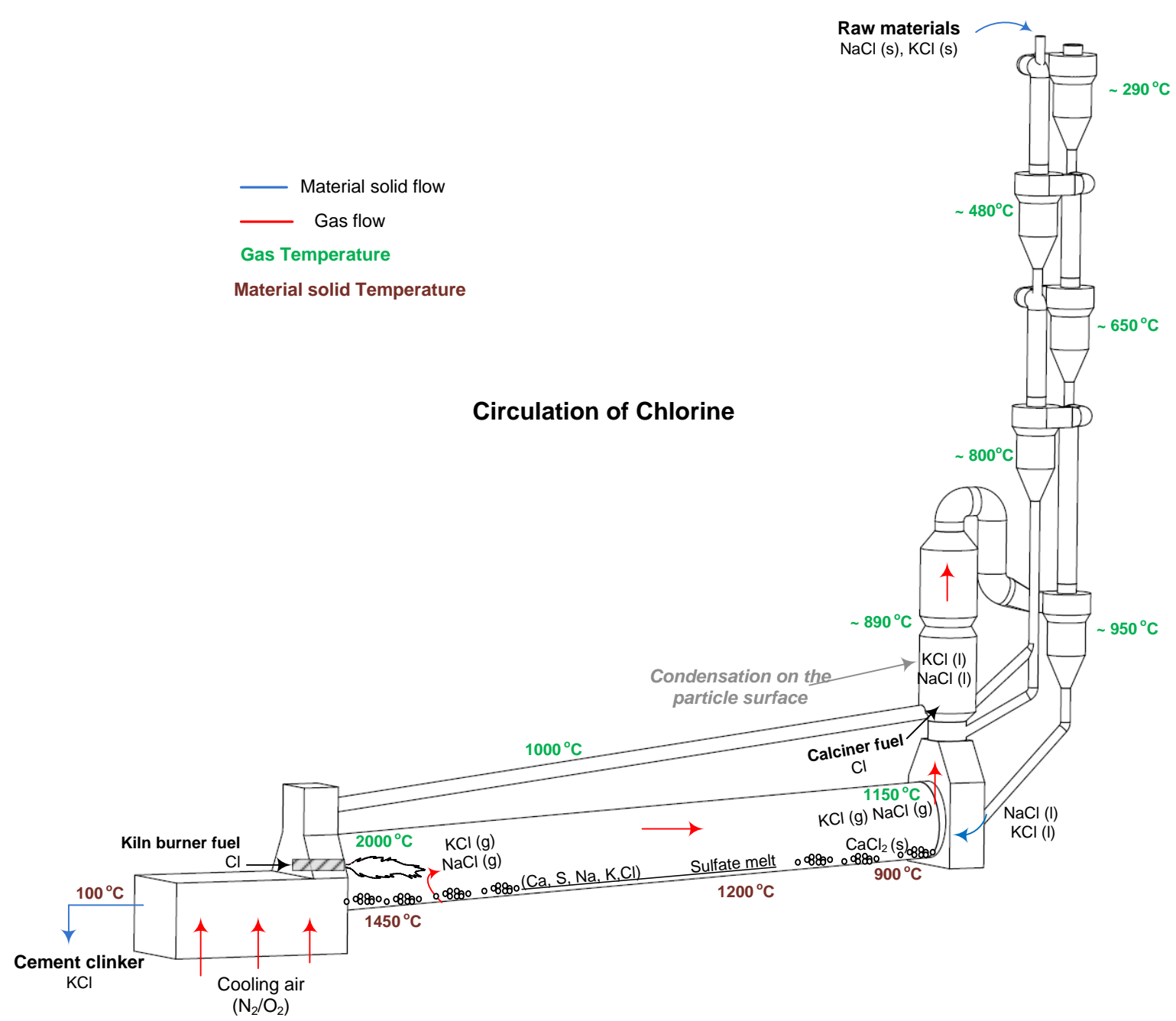

Figure 9. Circulation of the chlorine compounds in the kiln system. 


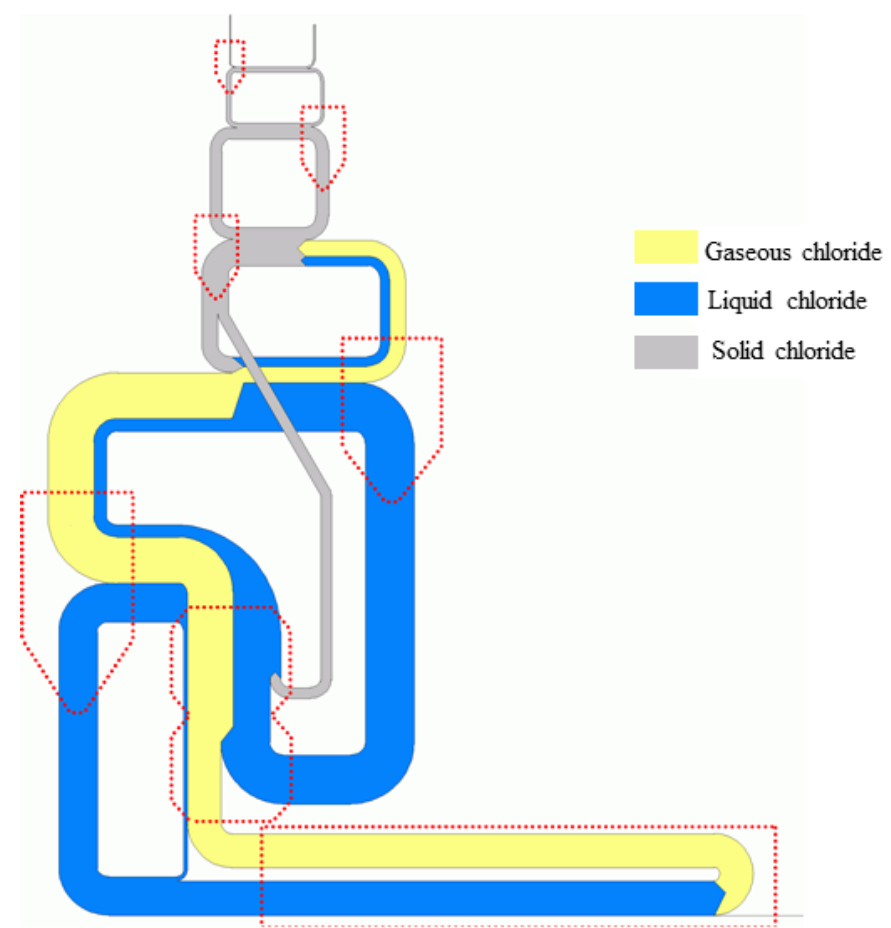

Figure 10. Sankey diagram for chlorine circulation in a modern calciner kiln showing the gaseous, liquid and solid chloride flows, adapted from Jøns et al. ${ }^{147}$. 


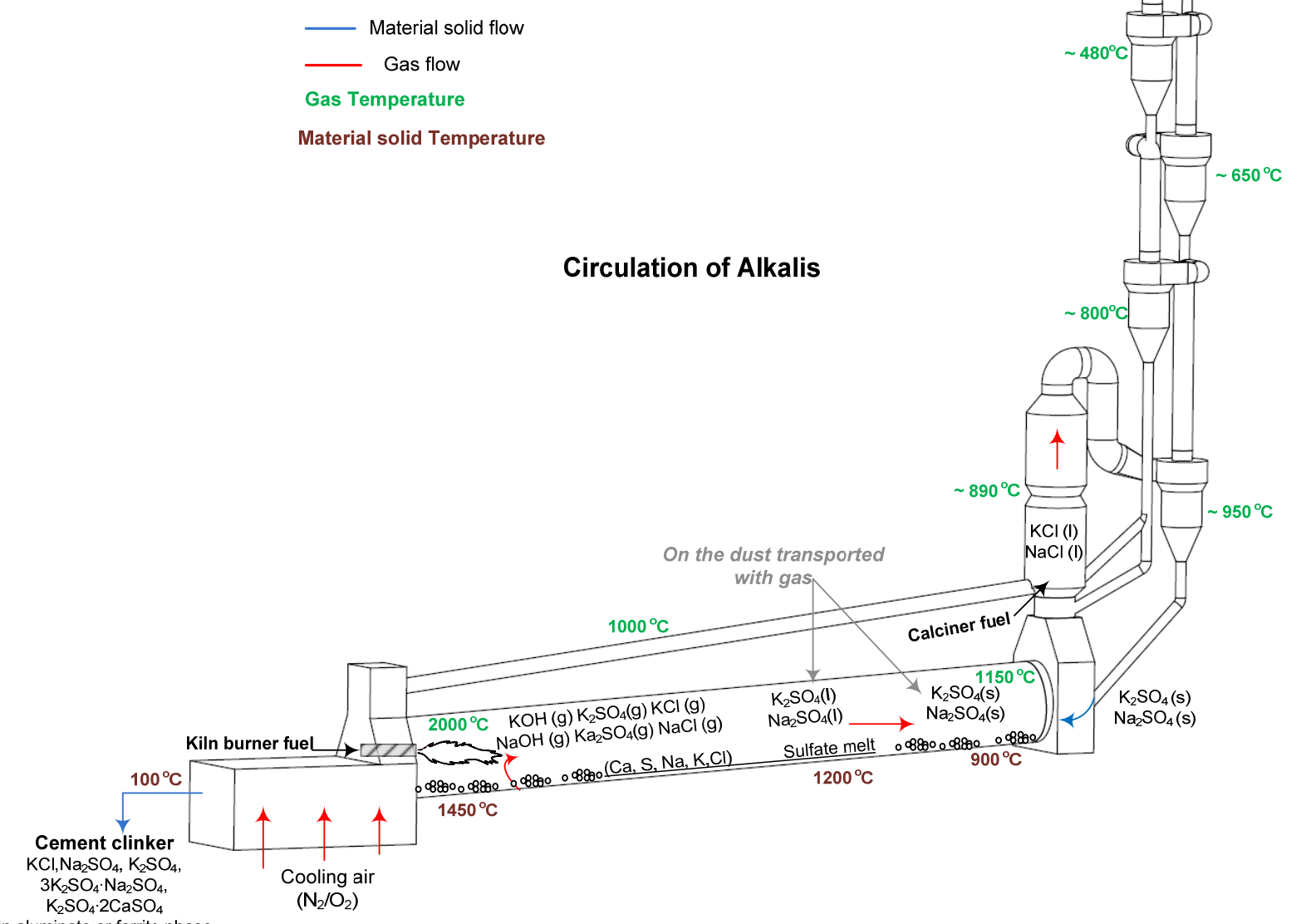

In aluminate or ferrite phase

Figure 11. Circulation of the alkali compounds in the kiln system. 


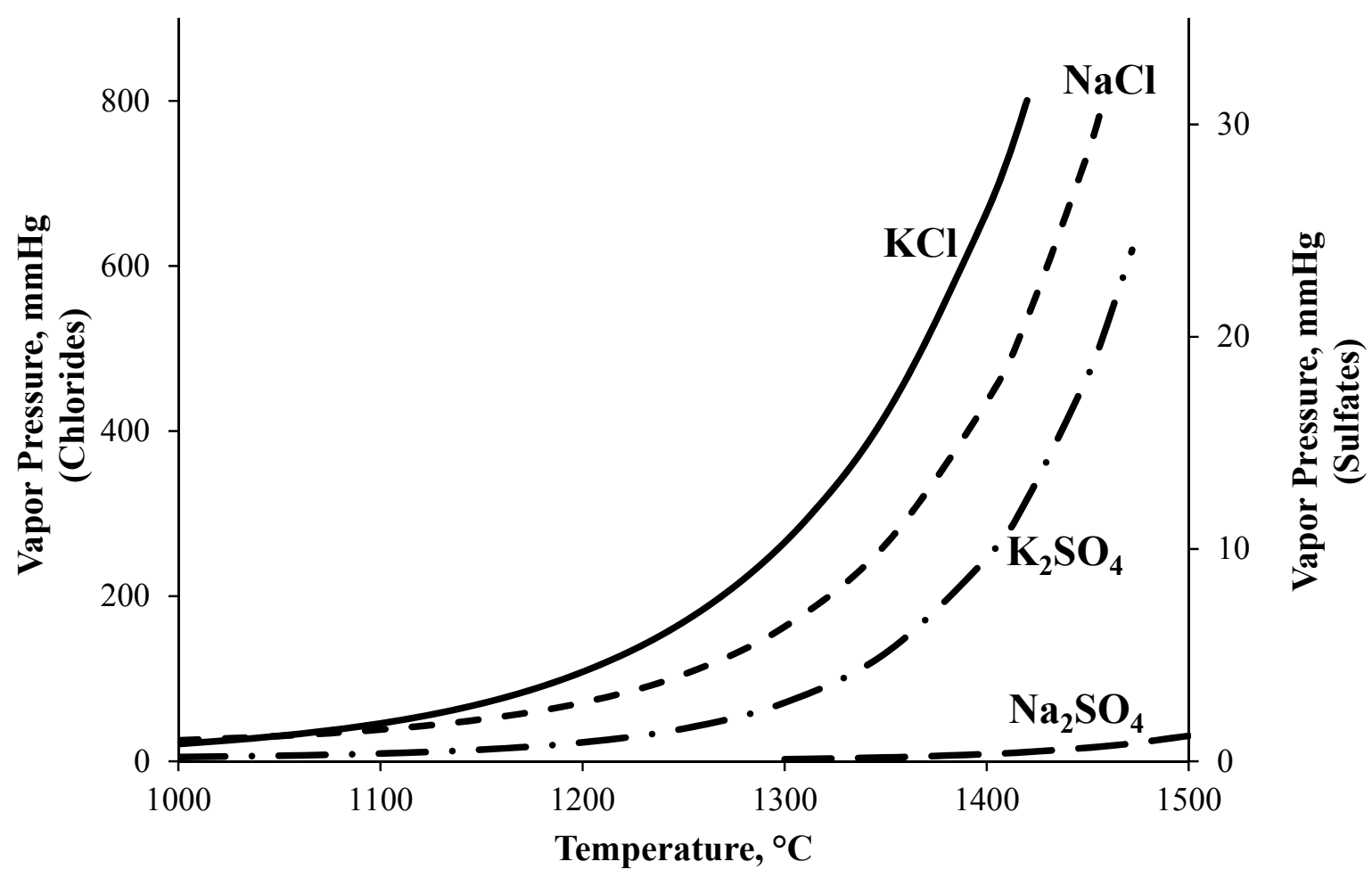

Figure 12. Vapor pressure of $\mathrm{Na}$ and $\mathrm{K}$ chlorides and sulfates, adapted from Bhatty ${ }^{124}$. 


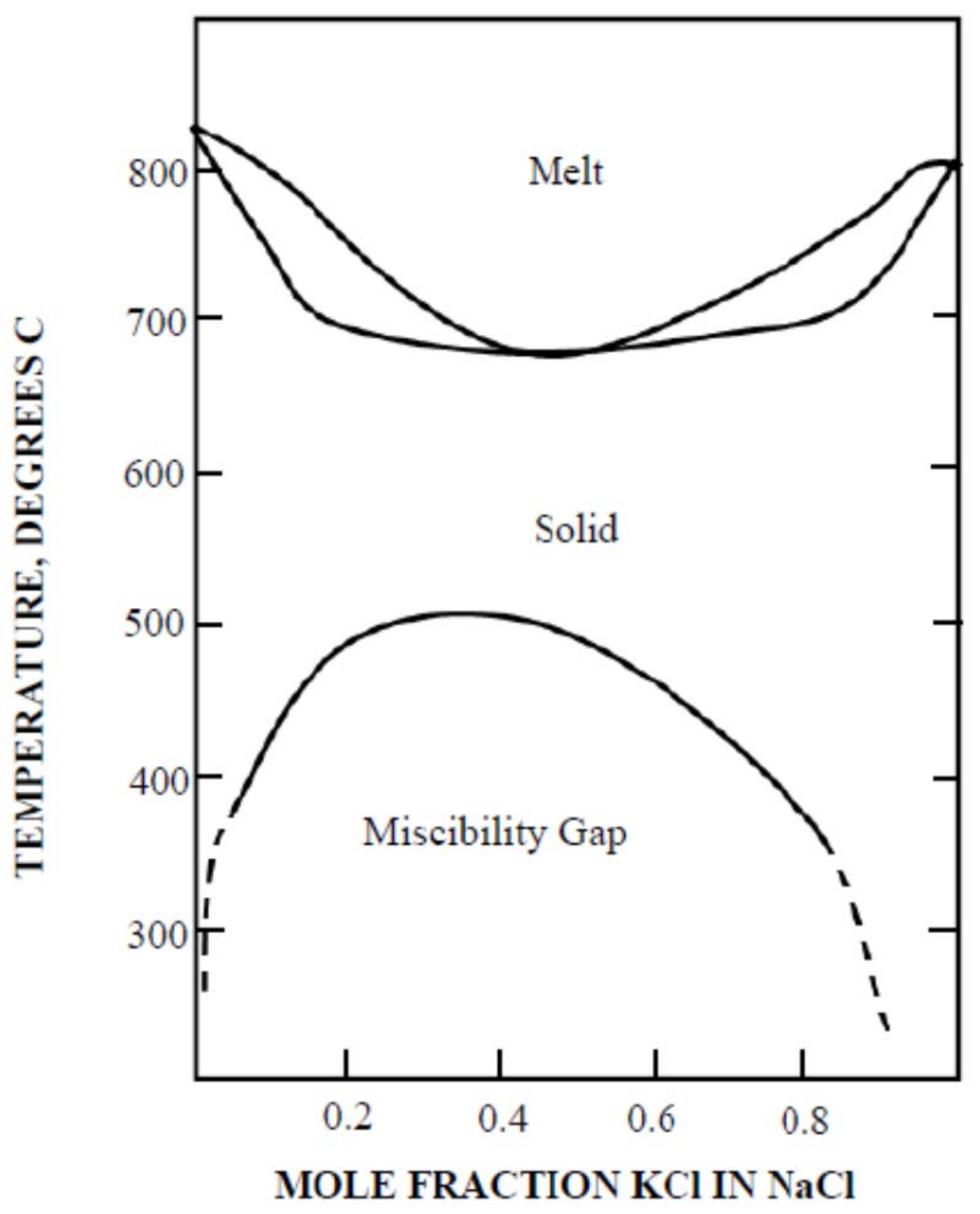

Figure 13. The $\mathrm{KCl}-\mathrm{NaCl}$ phase diagram, adapted from Wolfson et al. ${ }^{165}$. 


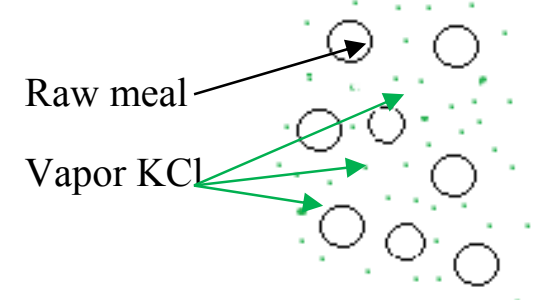

1. Presence of volatiles

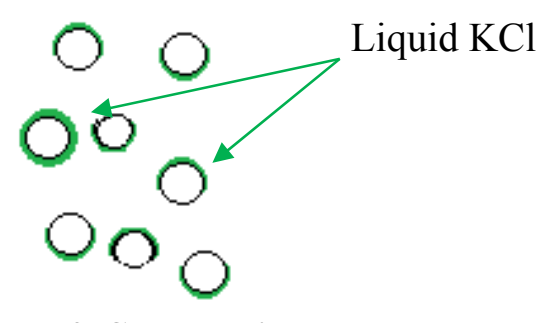

2. Condensation

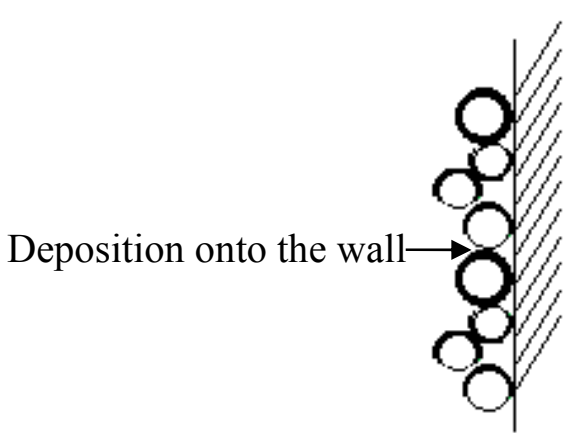

3. Agglomeration

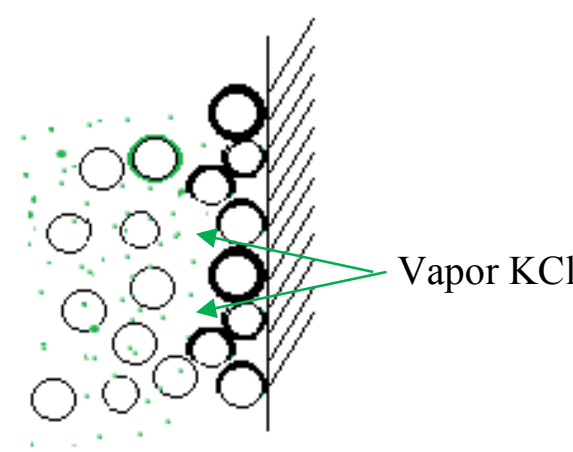

4. Good conditions for crystallization

Figure 14. Model of $\mathrm{KCl}$ crystallization, adapted from Kurdowski and Sobon ${ }^{166}$. 


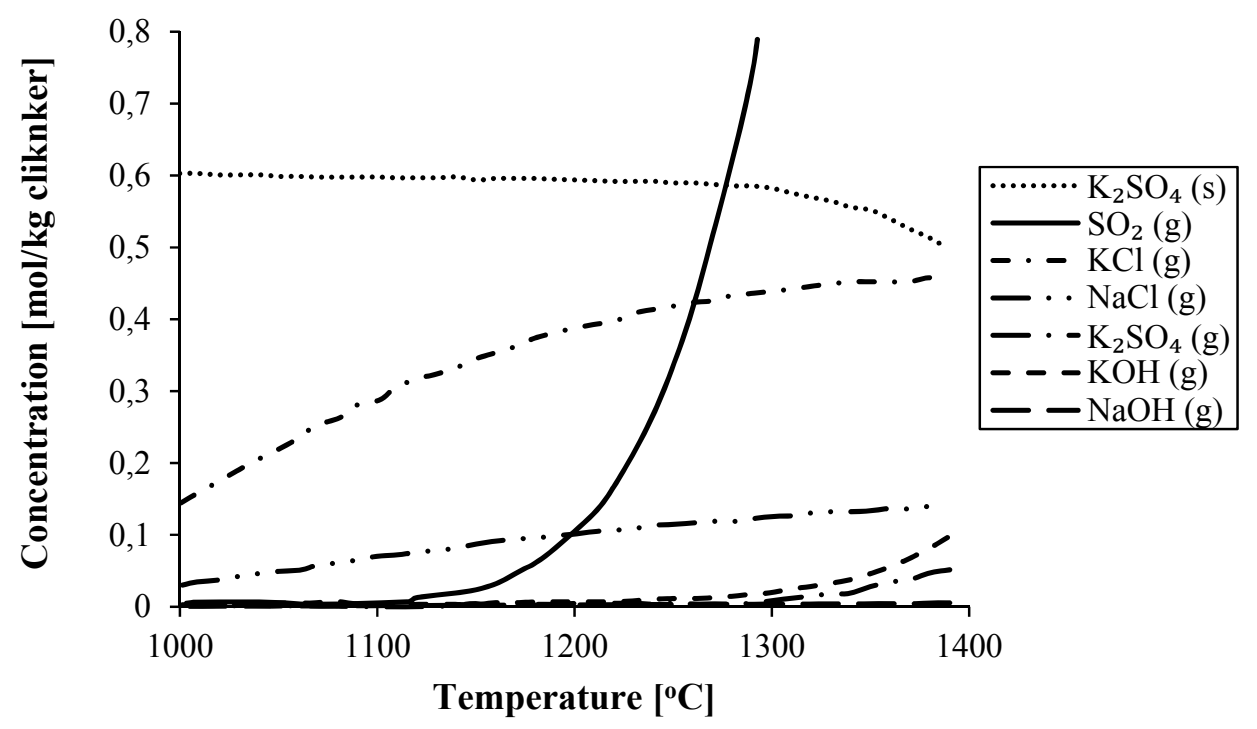

Figure 15. Thermodynamic calculations simulating the reactions with sufficient contact with lime-containing dust, adapted from Saint-Jean et al. ${ }^{162}$.

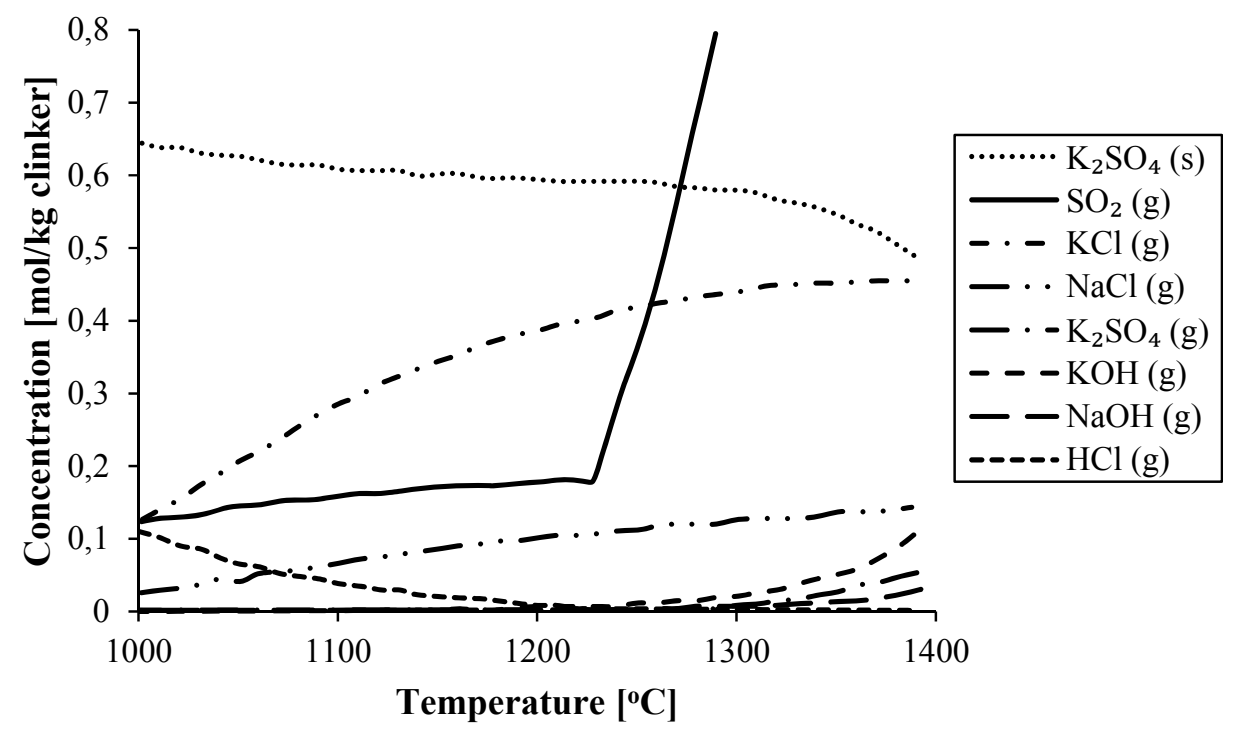

Figure 16. Thermodynamic calculations simulating the reactions with insufficient contact with lime-containing dust, adapted from Saint-Jean et al. ${ }^{162}$. 


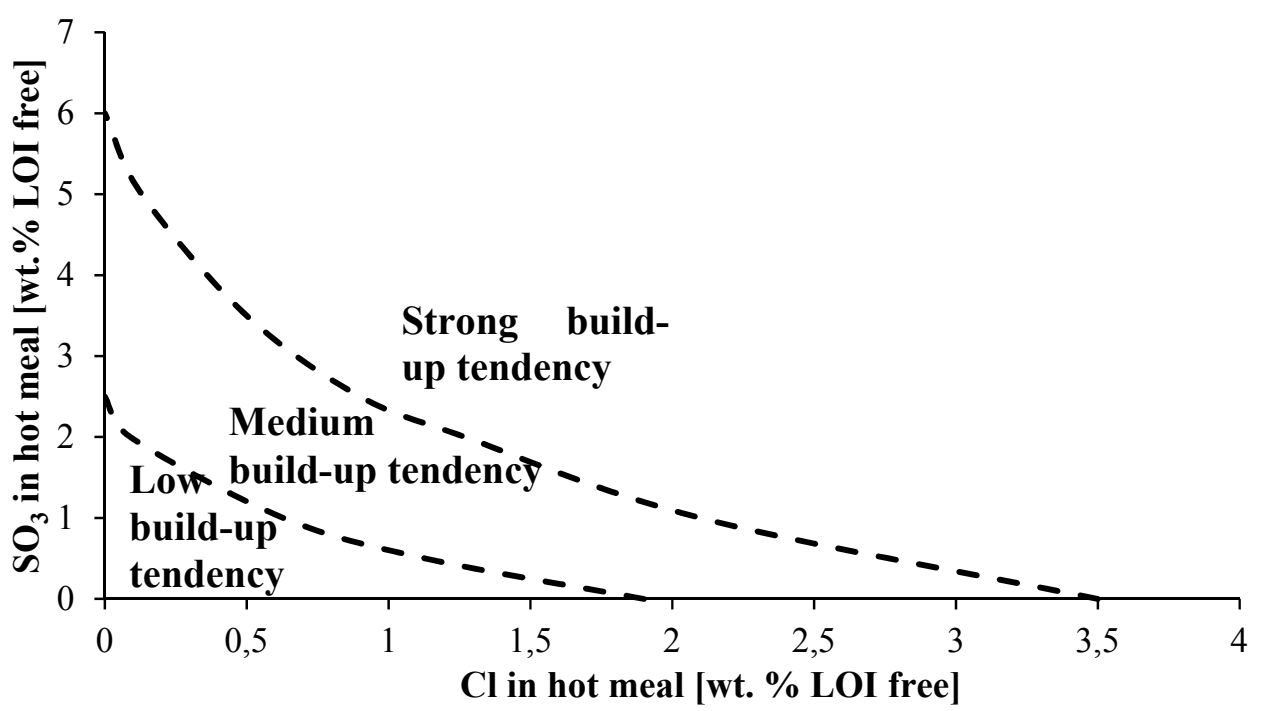

Figure 17. Evaluation diagram of build-ups tendency as a function of $\mathrm{SO}_{3}$ and $\mathrm{Cl}$ content in hot meal, modified from Edersen ${ }^{168}$.

(5)

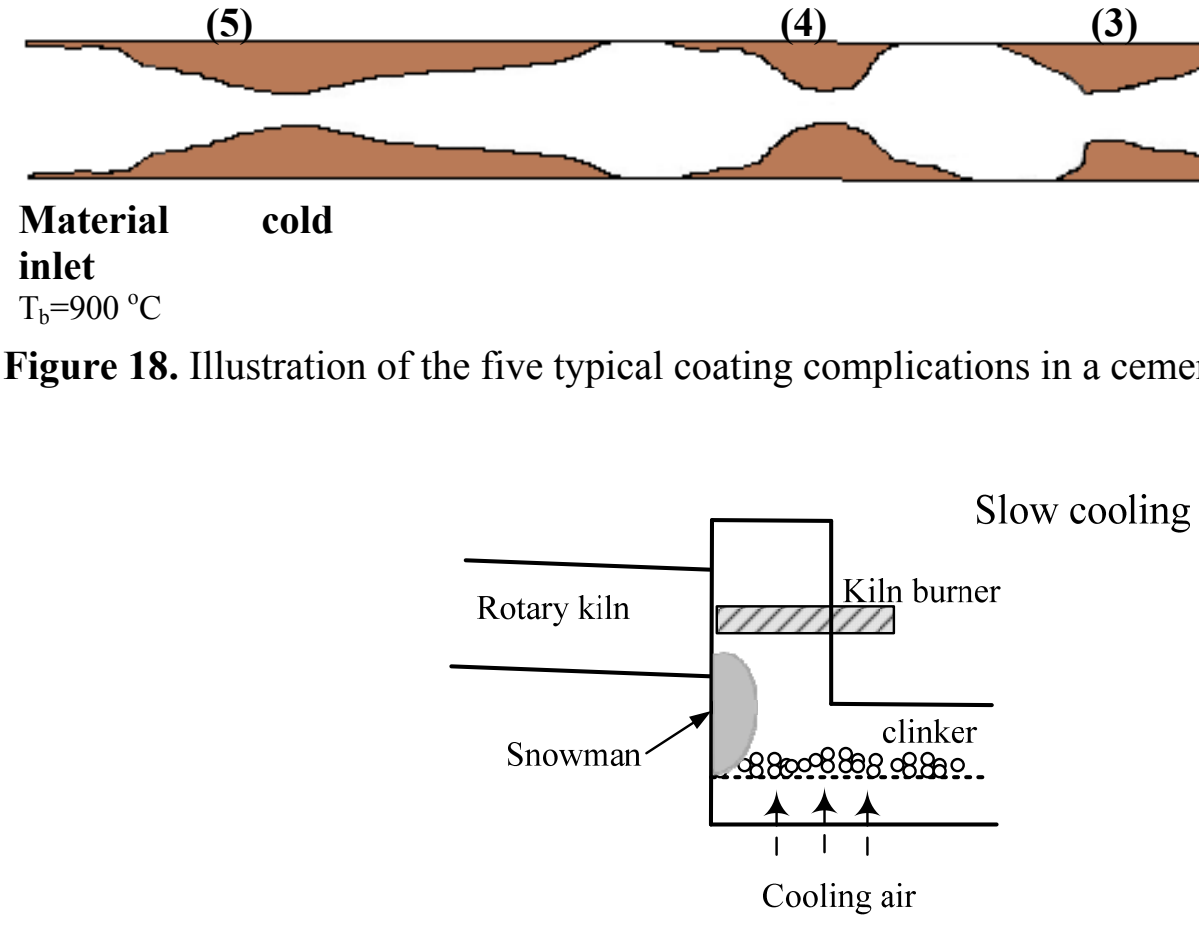

Figure 19. Illustration of the snowman build-up on the clinker cooler back wall, adapted from Hamilton $^{170}$.

\section{Hot burning zone} $\mathrm{T}_{\mathrm{b}}=1450^{\circ} \mathrm{C}$
(2)

(1) 


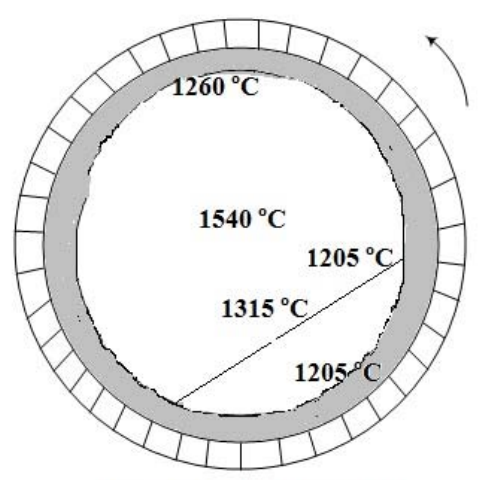

A) COLD FLAME

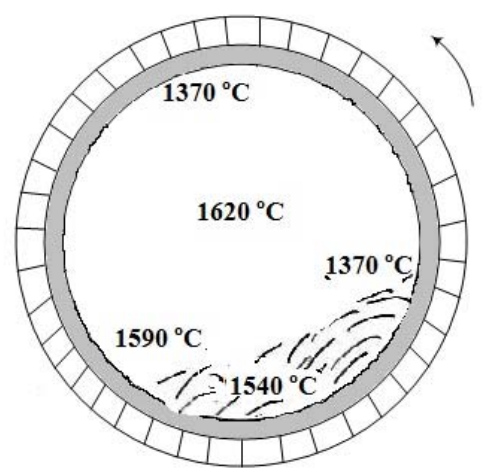

B) NORMAL FLAME

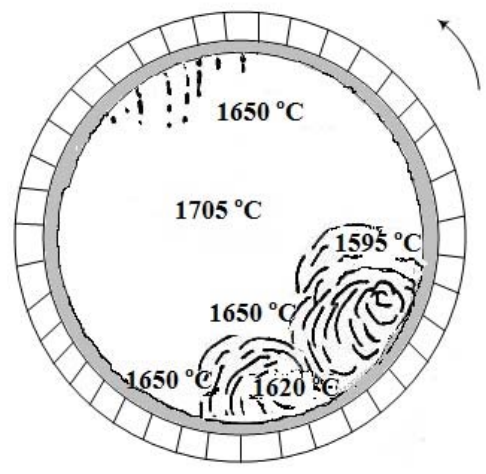

C) HOT FLAME

Figure 20. Influence of temperature on coating in rotary kiln, adapted from Peray and Waddell 169 


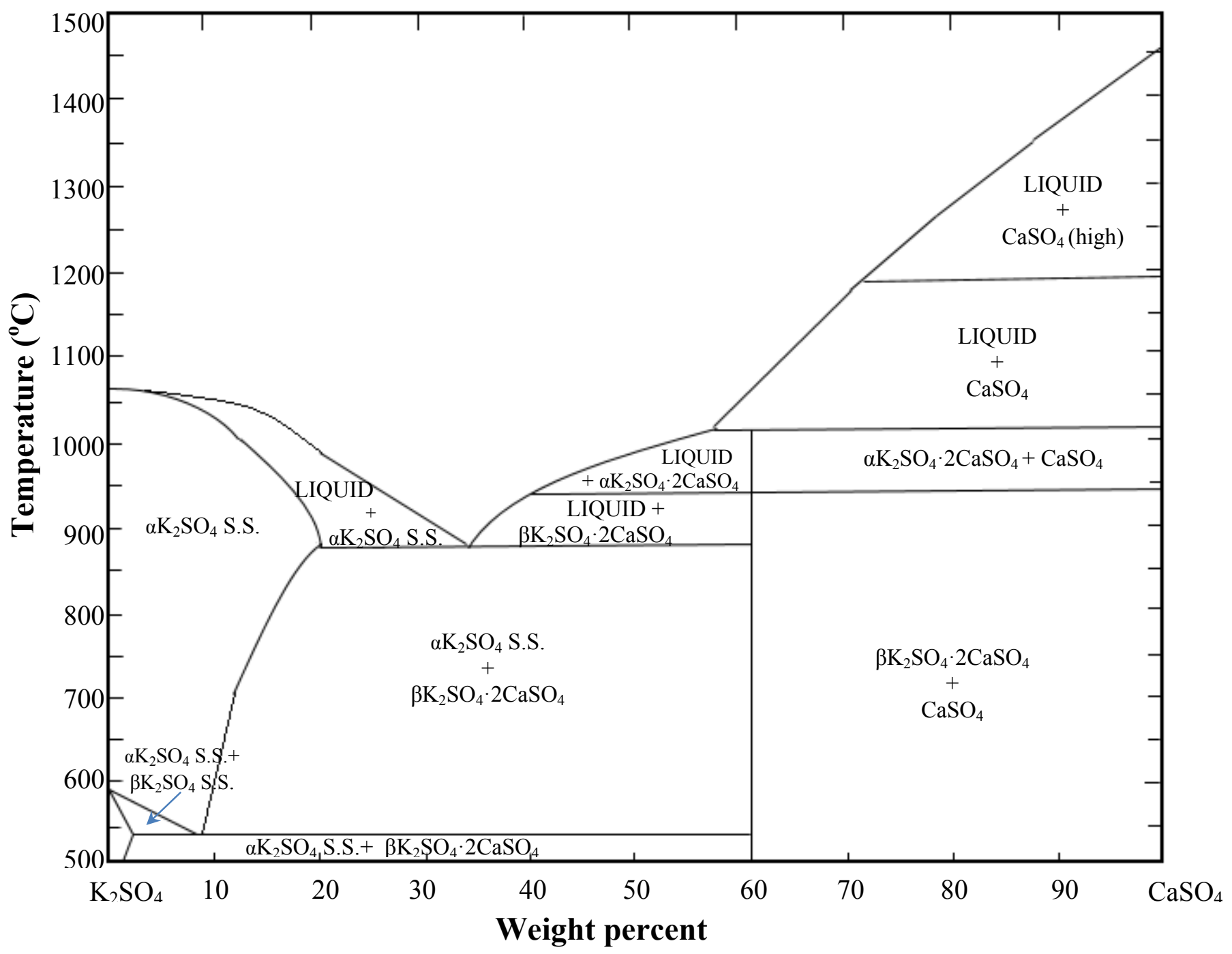

Figure 21. Phase diagram of $\mathrm{K}_{2} \mathrm{SO}_{4}-\mathrm{CaSO}_{4}$ system, adapted from Rowe et al. ${ }^{174}$. Note: S.S. indicates solid solution. 


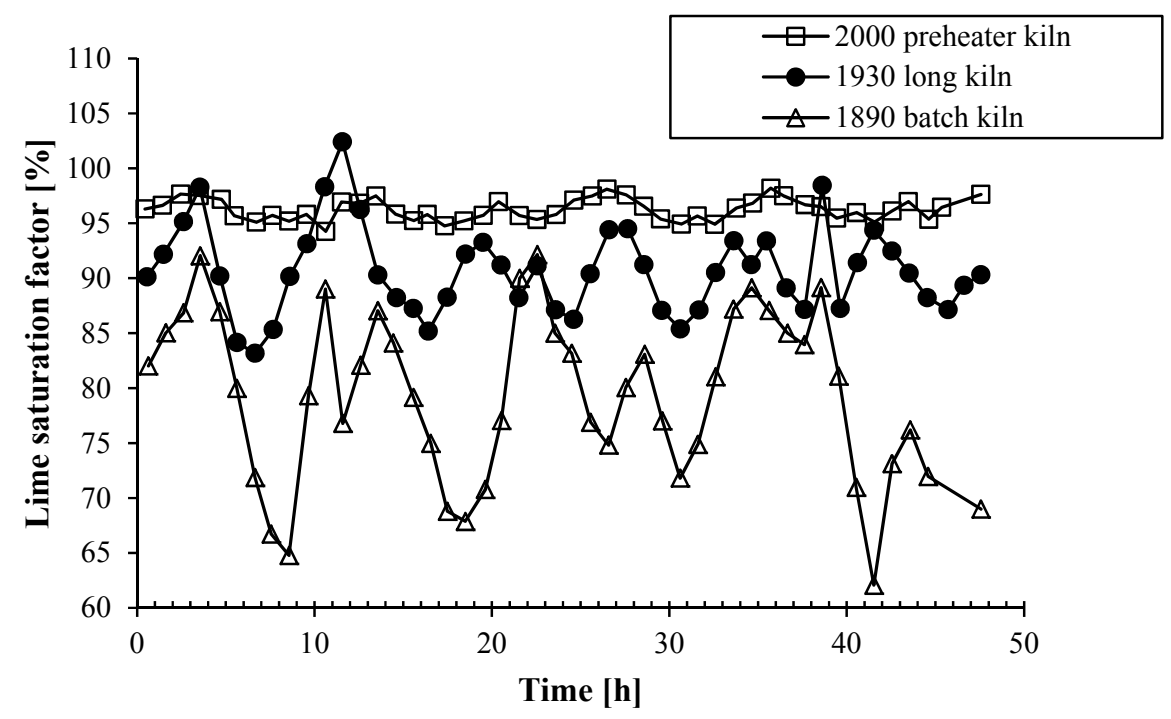

Figure 22. Variability in the lime saturation factor of hourly spot clinker samples of different cement rotary kilns, adapted from Herfort et al. ${ }^{175}$.

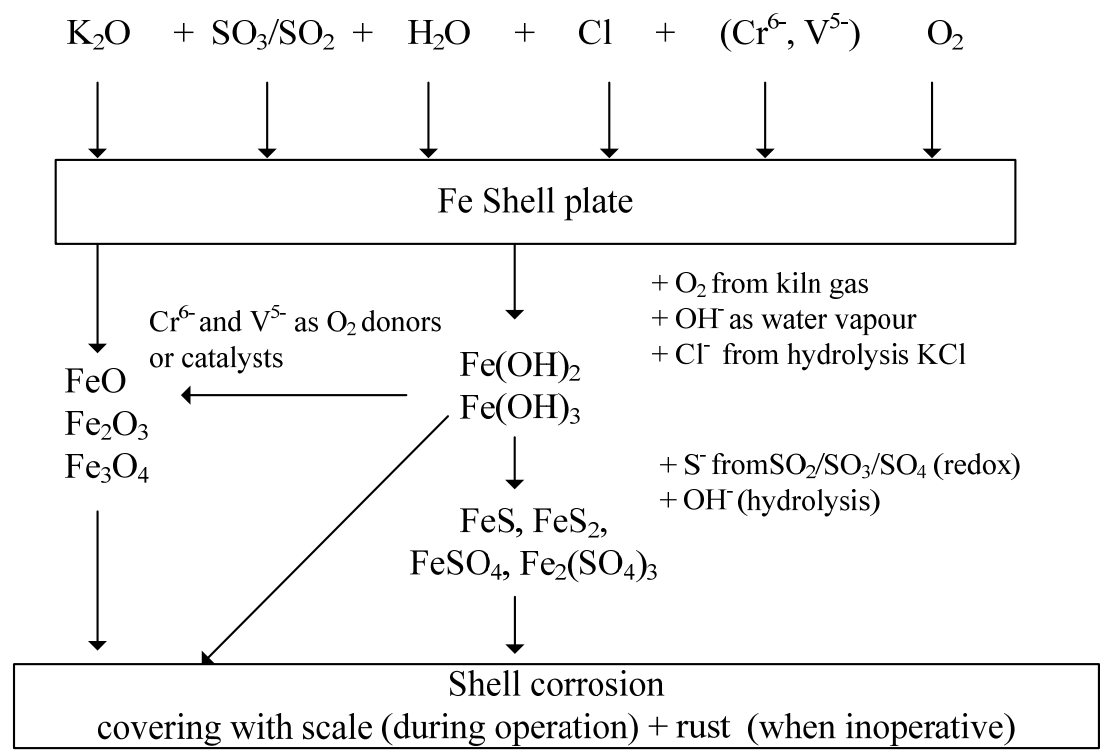

Figure 23. Schematic mechanism of shell corrosion, adapted from Kotter and Bartha ${ }^{177}$. 


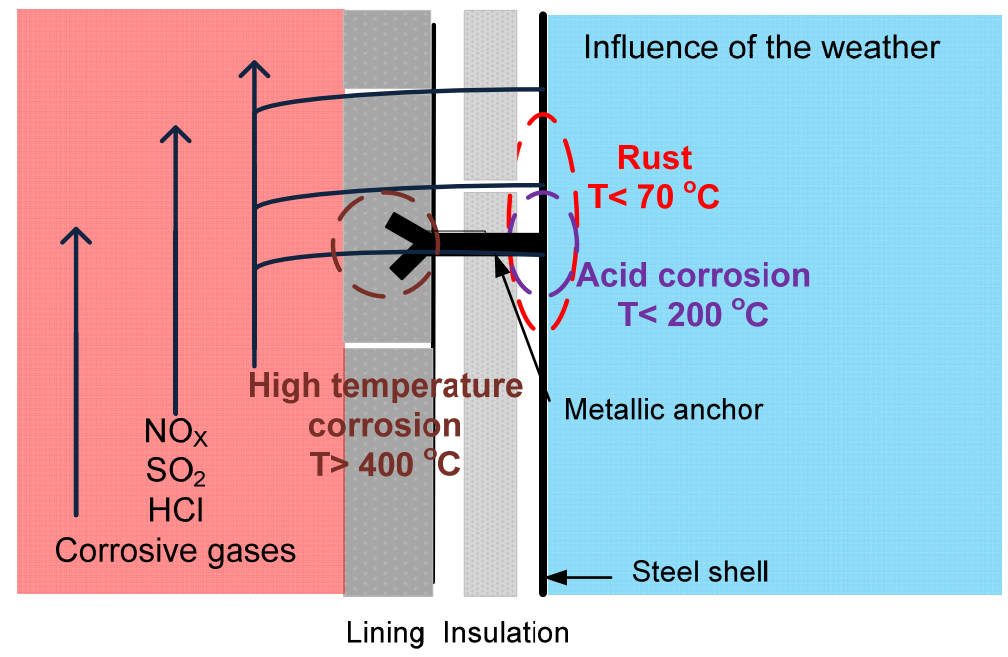

Figure 24. Scheme of the mechanism of corrosion, modified from Lechtenberg and Diller ${ }^{180}$.

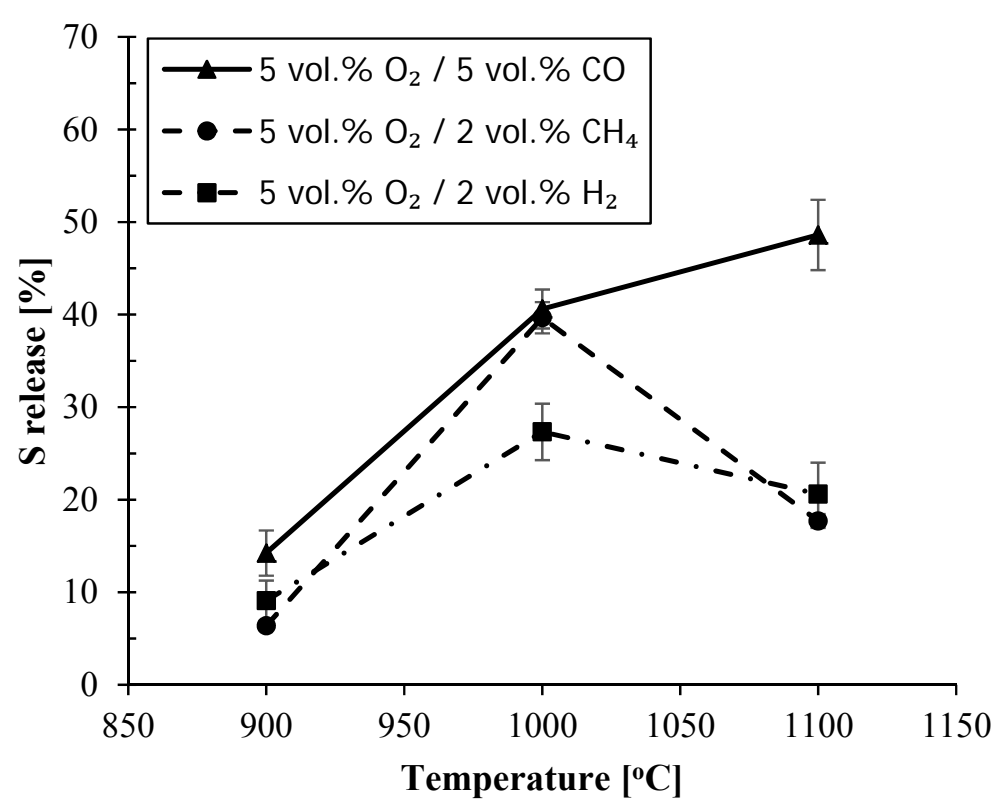

Figure 25. Effect of reducing agents on sulfur release from calcined raw material under alternating oxidizing and reducing conditions, adapted from Nielsen et al ${ }^{133}$. The sulfur release was quantified after 20 minutes of reaction time. 


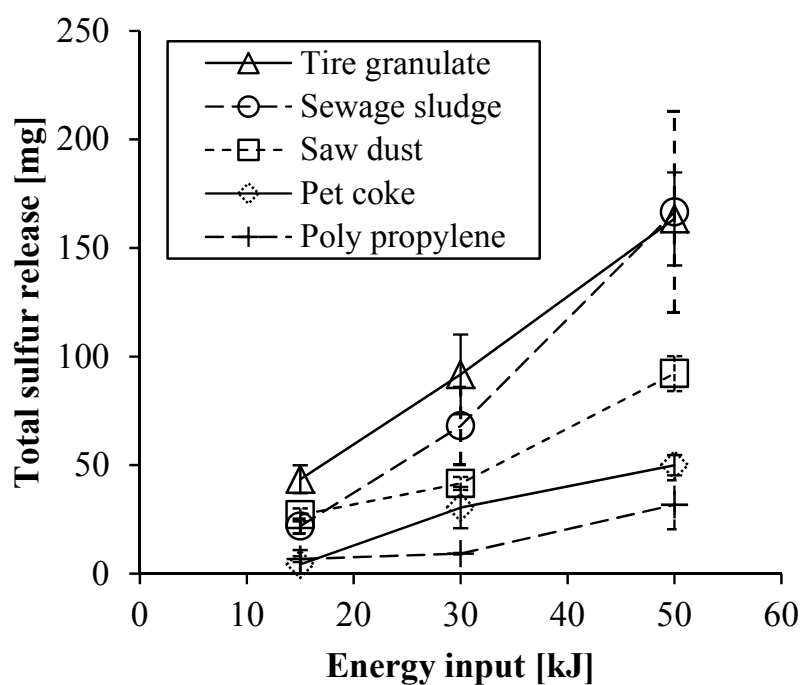

Figure 26. Effect of energy input from different Figure 27. Effect of temperature and particle fuels on total sulfur release. Conditions: $900^{\circ} \mathrm{C}$, size on total sulfur release. Conditions: $5 \%$ fill 10 vol. $\% \mathrm{O}_{2}, 5 \%$ fill, 5 wt. $\% \mathrm{CaSO}_{4}, 100$ degree, 5 wt. $\% \mathrm{CaSO}_{4}, 10$ vol. $\% \mathrm{O}_{2}, 100$ $\mathrm{NL} / \mathrm{min}, 6 \mathrm{rpm}$, adapted from Nielsen et al ${ }^{201}$. NL/min, $6 \mathrm{rpm}$. Energy input in each experiment: $30 \mathrm{~kJ}$. Note: Sulfur release form tire granulate and saw dust at $1000{ }^{\circ} \mathrm{C}$ has been estimated. Adapted from Nielsen et al. ${ }^{201}$. 


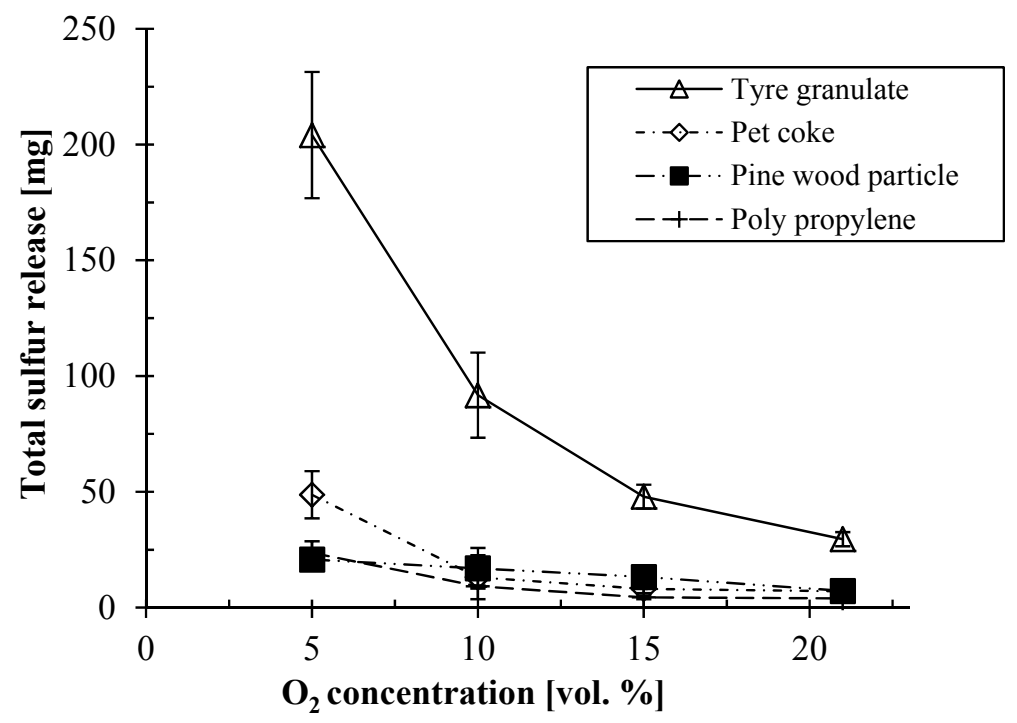

Figure 28. Effect of oxygen concentration on total sulfur for different fuels. Conditions: 5\% fill degree, 5 wt. $\% \mathrm{CaSO}_{4}, 900^{\circ} \mathrm{C}, 100 \mathrm{NL} / \mathrm{min}, 6 \mathrm{rpm}$. Energy input in each experiment: $30 \mathrm{~kJ}$, adapted from Nilsen et al. ${ }^{201}$.

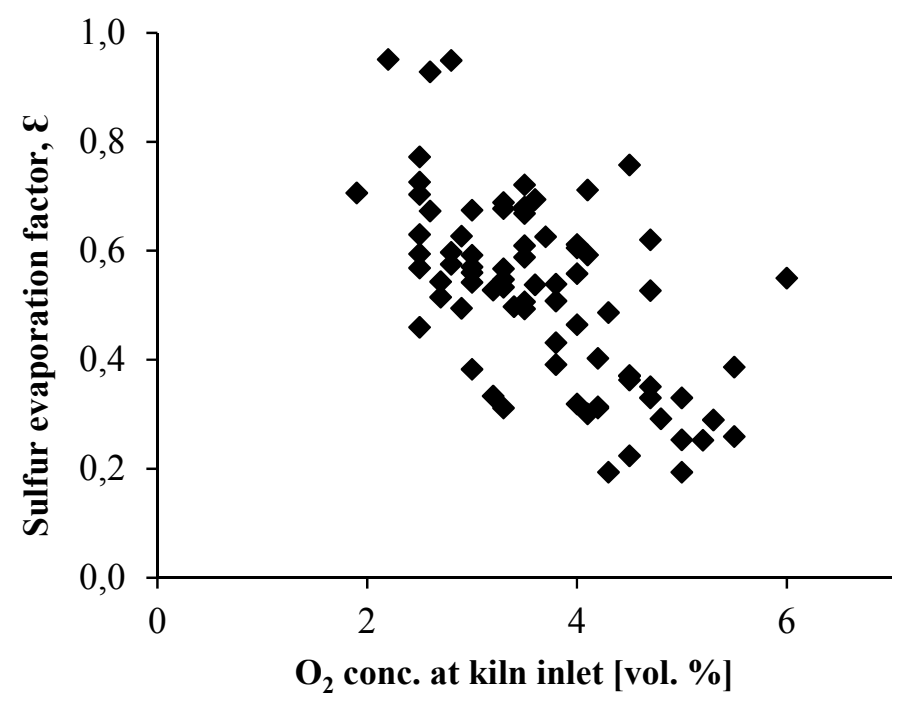

Figure 29. Sulfur evaporation factor as function of $\mathrm{O}_{2}$ exhaust gas concentration measured at the kiln material inlet during firing 0.5-2 tons per hour of dried sewage sludge in the kiln burner, adapted from Nørskov ${ }^{47}$. 
Table 1. Typical temperature, residence times, and oxygen concentration range in a modern calciner kiln ${ }^{11-13}$.

\begin{tabular}{lllll}
\hline & Preheater & Calciner & Rotary kiln & Cooler \\
\hline Gas temperature $\left[{ }^{\circ} \mathrm{C}\right]$ & $350-880$ & $880-1100$ & $1100-2000$ & $1100-25$ \\
Gas residence time $[\mathrm{s}]$ & $\sim 5-10$ & $\sim 3-4$ & $\sim 5-10$ & $\sim 1$ \\
\hline Material temperature $\left[{ }^{\circ} \mathrm{C}\right]$ & $100-780$ & $780-900$ & $900-1450$ & $1400-100$ \\
Material residence time $[\mathrm{s}]$ & $\sim 50$ & $\sim 5$ & $15-30 \mathrm{~min}$ & $\sim 30 \mathrm{~min}$ \\
\hline Gas $\mathrm{O}_{2}$ concentration $[$ vol.\%] & $\sim 3-12$ & $11-12$ & $2-7$ & $\sim 21$ \\
\hline
\end{tabular}

Table 2. Typical proximate analysis and heating values of different fossil fuels used in the cement production.

\begin{tabular}{l|lll|l|l}
\hline \multirow{2}{*}{ Fuels } & \multicolumn{3}{|l|}{$\begin{array}{l}\text { Proximate analysis [wt.\% } \\
\text { dry] }\end{array}$} & $\begin{array}{l}\text { Lower } \\
\text { heating } \\
\text { value } \\
{[\mathbf{M J} / \mathbf{k g}]}\end{array}$ & \multirow{2}{*}{ Reference } \\
\cline { 2 - 5 } & $\mathrm{VM}^{1}$ & $\mathrm{FC}^{2}$ & Ash & & \\
\hline Anthracite coal & $1.7-11$ & $67-98$ & $3.8-20$ & $30.2-34.9$ & \\
Bituminous coal & $14-40$ & $33-86$ & $3.7-12$ & $19.7-34.9$ & $35-38$ \\
Lignite coal & $26-47$ & $29-40$ & $4.2-18$ & $9.3-19.3$ & \\
Petcoke & $9-13$ & $71-95$ & $0.2-3.0$ & $29.5-34$ & $37,39-41$ \\
Crude oil & n.a & n.a & $\sim 0$ & $39-42.7$ & 39,42 \\
Natural gas & 100 & 0 & 0 & $46.8-53.8$ & 36,38 \\
\hline
\end{tabular}

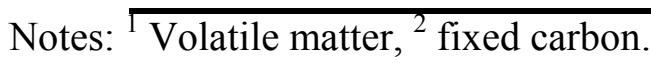


Table 3. Typical proximate analysis and heating values of different alternative fuels used in the cement production.

\begin{tabular}{|c|c|c|c|c|c|}
\hline \multirow[b]{2}{*}{ Fuels } & \multicolumn{3}{|c|}{ Proximate analysis [wt.\% dry] } & \multirow{2}{*}{$\begin{array}{l}\text { Lower heating } \\
\text { value }[\mathrm{MJ} / \mathrm{kg}]\end{array}$} & \multirow{2}{*}{ Reference } \\
\hline & $\mathrm{VM}^{1}$ & $\mathrm{FC}^{2}$ & Ash & & \\
\hline Pine wood & $79-83$ & $15-17$ & $0.3-0.5$ & $19.7-19.8 *$ & 56,57 \\
\hline Straw & $64.3-80.5$ & $\begin{array}{l}13- \\
19.5\end{array}$ & $4.7-20.1$ & $18.1^{*}$ & 58,59 \\
\hline Rice Husks & $61-69$ & $16-17$ & $15-20$ & $15.4^{*}$ & 35,57 \\
\hline $\begin{array}{l}\text { Refuse derived fuel } \\
\text { (RDF) }\end{array}$ & $60-84$ & $2-16$ & $8-32$ & 14 & 60,61 \\
\hline Tire Derived fuel (TDF) & $54-66$ & $23-30$ & $7-23$ & $31-32.8$ & 20,62 \\
\hline $\begin{array}{l}\text { Meat and Bone Meal } \\
(\mathrm{MBM})\end{array}$ & $65-72$ & $7.2-9.7$ & $18-28$ & $16.2-19.9$ & $63-65$ \\
\hline Polyethylene (PE) & 100 & $\sim 0$ & $\sim 0$ & $40.2-44.2 *$ & 66,67 \\
\hline $\begin{array}{l}\text { Poly-Vinyl-Chloride } \\
\text { (PVC) }\end{array}$ & 91 & 9 & 1 & 19.2 & 66,67 \\
\hline Sewage sludge & $48-64$ & $0-6$ & $17-50$ & $14.0-19.1$ & 47,57 \\
\hline
\end{tabular}

Notes: ${ }^{1}$ Volatile matter, ${ }^{2}$ fixed carbon, ${ }^{*}$ lower heating value calculated from the higher heating value. 
Table 4. Concentrations of $\mathrm{Na}_{2} \mathrm{O}, \mathrm{K}_{2} \mathrm{O}, \mathrm{Cl}$, and $\mathrm{SO}_{3}$ in the different raw materials.

\begin{tabular}{|c|c|c|c|c|}
\hline & Raw materials & & & \\
\hline Concentration [wt. \%] & $\begin{array}{l}\text { Limestone, lime } \\
\text { marl, chalk }\end{array}$ & Sand & $\begin{array}{l}\text { Clay, } \\
\text { shale }\end{array}$ & Reference \\
\hline $\mathrm{Na}_{2} \mathrm{O}$ & $0-0-1.5$ & $0.0-1.0$ & $0.1-1.5$ & $24,34,97,98$ \\
\hline $\mathrm{K}_{2} \mathrm{O}$ & $0.0-3.5$ & $0.2-3.0$ & $0.4-5.0$ & $24,34,97,98$ \\
\hline $\mathrm{Cl}$ & $0.0-0.6$ & Traces & $0.0-1.0$ & $24,34,99$ \\
\hline $\mathrm{SO}_{3}$ & $0.0-0.7$ & $0.0-0.5$ & 0.21 & 24,97 \\
\hline
\end{tabular}


Table 5. Concentrations of $\mathrm{S}, \mathrm{Cl}, \mathrm{Na}$ and $\mathrm{K}$ from the ultimate analysis of different fossil and alternative fuels.

\begin{tabular}{|c|c|c|c|c|c|}
\hline \multirow{2}{*}{ Fuels } & \multicolumn{4}{|c|}{ Ultimate analysis [wt.\% dry] } & \multirow{2}{*}{ Reference } \\
\hline & $\mathrm{S}$ & $\mathrm{Cl}$ & $\mathrm{Na}$ & $\mathrm{K}$ & \\
\hline $\begin{array}{l}\text { Anthracite } \\
\text { Coal }\end{array}$ & $0.7-2.2$ & $300-380 *$ & & & \\
\hline $\begin{array}{l}\text { Bituminous } \\
\text { coal }\end{array}$ & $0.3-4.3$ & $100-340^{*}$ & $0.09-2.9^{\#}$ & $0.29-4.15^{\#}$ & $35,37,38,59$ \\
\hline Lignite coal & $0.5-6.7$ & $100-140 *$ & & & \\
\hline Petcoke & $4-7.4$ & $\sim 0$ & $40-70 *$ & $20-50 *$ & $37,40,41$ \\
\hline Crude oil & $0-5.7$ & $\sim 0$ & n.a. & n.a. & 42 \\
\hline & & & & & 38,100 \\
\hline Natural gas & $0-0.34$ & $\sim 0$ & n.a. & n.a. & \\
\hline Pine wood & $\sim 0$ & $<0.1$ & n.a. & $\sim 1000^{*}$ & $36,56,57$ \\
\hline Straw & 0.2 & 0.6 & $0.16-3.5^{\#}$ & $12.6-38.5^{\#}$ & 59 \\
\hline Rice Husks & $0.1-0.2$ & n.a. & 0.1 & 2.2 & 35,57 \\
\hline RDF & $0.1-0.6$ & $0.1-3.9$ & $0.1-0.2$ & $0-0.1$ & 60,61 \\
\hline $\mathrm{TDF}$ & $1.4-1.6$ & $0.2-2$ & $\sim 0$ & $\sim 0$ & 101,102 \\
\hline MBM & $0.4-1.0$ & $0.4-0.6$ & 0.31 & 0.1 & $63-65$ \\
\hline $\mathrm{PE}$ & $\sim 0$ & $\sim 0$ & $\sim 0$ & $\sim 0$ & 66,67 \\
\hline PVC & $\sim 0$ & 57 & $\sim 0$ & $\sim 0$ & 66,67 \\
\hline Sewage sludge & $\sim 1$ & $0.1-0.8$ & 0.24 & $0.3-0.63$ & $21,54,57$ \\
\hline
\end{tabular}

Note: *Concentration in ppm weight dry basis, ${ }^{\#}$ Chemical ash composition as wt. $\% \mathrm{Na}_{2} \mathrm{O}$ and $\mathrm{K}_{2} \mathrm{O}$, n.a.: not available 
Table 6. Common intermediate compounds found in build-ups and kiln rings ${ }^{162,163}$.

\begin{tabular}{|c|c|c|}
\hline Name & Formula & Location typically found \\
\hline Spurrite & $\left(2 \mathrm{CaO} \cdot \mathrm{SiO}_{2}\right)_{2} \cdot \mathrm{CaCO}_{3}$ & Lower cyclones \\
\hline Ellestadite & $\begin{array}{l}\mathrm{Ca}_{10}\left(\mathrm{SiO}_{4}\right)_{3}\left(\mathrm{SO}_{4}\right)_{3} \mathrm{Z}_{2} \\
\mathrm{Z}=\mathrm{OH}, \mathrm{F}, \mathrm{Cl}\end{array}$ & Riser pipes \\
\hline Sulfospurrite & $\left(2 \mathrm{CaO} \cdot \mathrm{SiO}_{2}\right)_{2} \cdot \mathrm{CaSO}_{4}$ & Kiln rings \\
\hline Anhydrite & $\mathrm{CaSO}_{4}$ & Cyclone and riser pipe \\
\hline
\end{tabular}

Table 7. Chemical composition of the corrosion sample at a distance of $48.5 \mathrm{~m}$ and 53 from the kiln inlet ${ }^{151}$.

\begin{tabular}{lll}
\hline & \multicolumn{2}{l}{ Distance from kiln inlet [m] } \\
$\begin{array}{l}\text { Chemical composition } \\
\text { [wt.\%] }\end{array}$ & 48.5 & 53 \\
\hline $\mathrm{Fe}_{2} \mathrm{O}_{3}$ & 92 & 70 \\
$\mathrm{~K}_{2} \mathrm{O}$ & 0.9 & 3.9 \\
$\mathrm{~S}$ & 2.1 & 16.8 \\
$\mathrm{Cl}$ & 1.7 & 6.6 \\
\hline
\end{tabular}

\section{REFERENCES}

1. van Oss, H. G. Background Facts and Issues Concerning Cement and Cement Data. 2005, U.S. Geological Survey Open-File Report 2005-1152.

2. U.S. Geological Survey. Minerals Yearbook 2007, Cement. 2007. Available at http://minerals.usgs.gov

3. U.S. Geological Survey. Mineral Commodity Summaries- Cement. 2014. Available at http://minerals.usgs.gov 
4. VDZ Activity Report 2007-2009. 2009. Available at http://www.vdz.de.

5. Worrell, E.; Price, L.; Martin, N.; Hendriks, C.; Meida, L. O. Annu. Rev. Energy Environ. 2001, 26, 303-329.

6. CEMBUREAU. Sustainable cement production: Co-processing of alternative fuels and raw materials in the cement industry. 2009. Available at htt://cembureau.be

7. Greco, R.; Enfil, G. World Cement 2006, 37, 33-38.

8. Pizant, J.; Gauthier, J. C. World Cement 1997, 9, 64-74.

9. Mokrzycki, E.; Uliasz-Bochenczyk, A. Appl. Energy 2003, 74, 95.

10. Zhu, Q. CO2 abatement in the cement industry. 2011, IEA Clean coal center CCC/193. ISBN: 978-92-9029-504-4.

11. Hewlett, P. C. Lea's Chemistry of Cement and Concrete, 4th Ed, New York, 1998. ISBN: 978-0-7506-6256-7.

12. Bye, G. C. Portland Cement, 2nd Ed, Thomas Telford, London, 1999. ISBN: 0-7277-2766-4.

13. Taylor, H. F. W. Cement Chemistry, 2nd Ed, Academic Press Thomas Telford, London, 1997. ISBN: 978-0727725929.

14. Telschow, S.; Frandsen, F. J.; Theisen, K.; Dam-Johansen, K. Ind Eng Chem Res 2012, 51, 10983-11004.

15. Hills, L. M.; Johansen, V.; MacGregor Miller, G. IEEE/IEA-PCA 44th Cem. Ind. Tech. Co 2002, 129-150.

16. Johansen, V.; Kouznetsova, T. V. 9th International Congress on the Chemistry of Cement 1992,49

17. FLSMIDTH A/S. In-Line Calciner Preheater System. 2014. Available at www.flsmidth.com (accessed 20/05/2014).

18. Madlool, N. A.; Saidur, R.; Hossain, M. S.; Rahim, N. A. Renew. Sust. Energ. Rev. 2011, 15, 2042-2060.

19. Jensen, L. S. NOx from cement production-Reduction by primary measures, $\mathrm{PhD}$ thesis, Technical University of Denmark, 1999. ISBN: 87-90142-55-1.

20. Larsen, M. B. Alternative fuels in Cement production, $\mathrm{PhD}$ thesis, Technical University of Denmark, 2007. ISBN: 978-87-91435-49-8.

21. Nielsen, A. R. Combustion of large solid fuels in cement rotary kilns. PhD thesis, Technical University of Denmark, 2012. ISBN: 978-87-92481-66-5.

22. CEMBUREAU. Best available techniques for the cement industry. 1999. Available at htt://cembureau.be 
23. FLSmidth A/S. Overcoming side effects of alternative fuels on pyro process. Highlights 28 , November 2008.

24. European Integrated Pollution Prevention and Control Bureau. Best Available Techniques (BAT) reference document for the Production of Cement, Lime and Magnexium Oxide. 2013.

25. Suto, K.; Kaneko, Y. International Cement Review 2004, 4, 75-82.

26. Scheuer, A. Cement International 2003, 1, 40-65.

27. Asthana, S. R.; Patil, R. K. Adv.Energy Res. 2006, 347-349.

28. Schneider, M.; Romer, M.; Tschudin, M.; Bolio, H. Cem. Concr. Res. 2011, 41, 642-650.

29. Karagiannis, J.; Ftikos, C.; Nikojopouios, P. Wit. Trans. Ecol. Envir. 2008, 109, 105-114.

30. VDZ Activity Report 2009-2012. 2009. Available at www.vdz.de/.

31. CW Group. Alternative fuels in Spain and in the rest of Europe. CemWeek Magazin Issue 17 2013.

32. Mitsubishi Heavy Industries. History of Fossil Fuel Usage since the Industrial Revolution, 2010. Available at http://www.mhi-global.com. (Accessed 21/03/2014)

33. Roy, G. R. World Cement 2002, 33, 71-74.

34. Bhatty, J. I.; Miller, F. M.; Kosmathka, S. K. Innovations in Portland Cement Manufacturing; Illinois, USA, 2011. ISBN: 978-0893122713.

35. Tsubouchi, N.; Ohtsuka, S.; Nakazato, Y.; Ohtsuka, Y. Energy Fuels 2005, 19, 554-560.

36. Weston, K. C. Energy Conversion. ws Pub Co. 1992. ISBN: 978-0534938611.

37. Singer, J. G. Combustion Fossil Power: A reference book on Fuel burning and Steam Generation; 4th Ed, Combustion engineering, Inc, U.S.A., 1993. ISBN: 0-9605974-0-9.

38. Zevenhoven, R.; Kilpinen, P. In Chapter 3: Sulphur; Control of pollutants in flue gases and fuel gases; Helsinki University of Technology, Finland, 2004; Book online http://users.abo.fi/rzevenho/gasbook.html

39. US Department of Energy. Hydrogen and Fuel Cells Program: Lower and higher heating values of hydrogen and fuels, 2012. Available at http://hydrogen.pnl.gov/. (Accessed 25/02/2012).

40. Milenkova, K. S.; Borrego, A. G.; Alvarez, D.; Xiberta, J.; Menendez, R. Fuel 2003, 82, 1883-1891.

41. American Fuel and Petrochemical Manufactures; Petroleum coke overview, 2012. Available at http://www.afpm.org/policy-position-petroleum-coke/ (Accessed 28/08/2014). 
42. Babcock \& Wilcox Co. Steam, its generation and use; 2007, Ebook\#22657. Available at http://www.gutenberg.org .

43. Smoot, L. D. Energy Fuels 1993, 7, 689-699.

44. Gorbaty, M. L. Fuel 1994, 73, 1819-1828.

45. Hundebøl, S.; Rosholm, P. International Cement Review 1994.

46. Hundebøl, S.; Nielsen, H.; Nielsen, P. B. Frist NCB International Seminar "Pragmatic Strategies for Productivity and Modernisation" 1987, New Delhi.

47. Nørskov, L. K. PhD thesis, Technical University of Denmark, Denmark, 2012. ISBN: 97887-92481-66-5.

48. Lahaye, J.; Prado, G.; Fundamentals of the physical-chemistry of pulverized coal combustion, Proc. NATO Adv. Res. Worksh., Springer Science \& Business Media, France, 1987. ISNB: 978-94-009-3661-4.

49. Osborne, D. The Coal Handbook: Towards Cleaner Production; Woodhead Publishing: Australia, 2013. ISBN: 978-1-78242-116-0.

50. Battelle, P. N.L. Chemical Characterization of Fossil Fuel Combustion Wastes, Electrical Power Research Institute, report EA-5321, Washington, USA. 1987.

51. Gorbaty, M. L.; Kelemen, S. R. Fuel Process. Technol. 2001, 71, 71-78.

52. Lee, J. M.; Baker, J. J.; Rolle, J. G.; Lierena, R. Abstr. Pap. Am. Chem. S. 1999, 217, U810U810.

53. Trezza, M. A.; Scian, A. N. Mater. Res-Ibero-Am J. 2009, 12, 489-494.

54. Zabaniotou, A.; Theofilou, C. Renew. Sust. Energ. Rev. 2008, 12, 531-541.

55. Mackes, K. H.; Lightburn, C. R. For. Prod. J. 2003, 53, 42-47.

56. Hassan, E. M.; Steele, P. H.; Ingram, L. Appl. Biochem. Biotechnol. 2009, 154, 3-13.

57. BioBank Biomass database from IEA Bionernergy Task 32. BIOS Bioneregiesysteme GmbH, Graz Austria. 2013. Available at http://ieabcc.nl/database/biomass.php.

58. Stenseng, M. Pyrolysis and combustion of biomass. $\mathrm{PhD}$ thesis, Technical University of Denmark, 2001. ISBN: 87-90142-65-9.

59. Vassilev, S. V.; Baxter, D.; Andersen, L. K.; Vassileva, C. G. Fuel 2010, 89, 913-933.

60. Tokheim, L. The impact of staged combustion on the operation of a precalciner cement kiln. $\mathrm{PhD}$ thesis, Institute of Environmental Technology, Norway, 1999.

61. Kobyashi, N.; Itaya, Y.; Piao, G.; Mori, S.; Kondo, M.; Hamai, M.; Yamaguchi, M. Powder Technol. 2005, 151, 87-95. 
62. Chinyama, M. P. M.; Lockwood, F. C. J. Energy Institute 2007, 80, 162-167.

63. Aho, M.; Ferrer, E. Fuel 2005, 84, 201-212.

64. Ayllon, M.; Aznar, M.; Sanchez, J. L.; Gea, G.; Arauzo, J. Chem. Eng. J. 2006, 121, 85-96.

65. Kaantee, U.; Zevenhoven, R.; Backman, R.; Hupa, M. Fuel Process Technol 2004, 85, 293 301.

66. Panagiotou, T.; Levendis, Y. Combust. Flame 1994, 99, 53-74.

67. Wang, Z.; Richter, H.; Howard, J. B.; Jordan, J.; Carlson, J.; Levendis, Y. Ind.Chem.Eng.Res. 2004, 43, 2873.2886.

68. Directive 2010/75/EU. The industrial Emissions Directive. Available at http://europa.eu. (Accessed 24/04/2015)

69. Bolwerk, R. VDZ Congress 2002, 380-383.

70. Scur, S. VDZ Congress 2002, 479-483.

71. Axelsen, E. P.; Tokheim, L. A.; Bjerketvedz, D. ZKG International 2003, 56, 54-63.

72. Syverud, T.; Thomasson, A.; Gautestard, T. World Cement 1994, 39-43.

73. Giugliano, M.; Cernuschi, S.; Ghezzi, U.; Rosso, M. J. Air Waste Manage. Assoc. 1999, 49, 1405-1414.

74. Tokheim, L. A.; Bjerketvedt, D.; Husum, I.; Hoidalen, O. ZKG International 1998, 51, 1223.

75. Lang, T. A. Cement International 2003, 4, 62-70.

76. Zevenhoven, R.; Kilpinen, P. In Chapter 8: Trace elements, alkali metals; Control of pollutants in flue gases and fuel gases; Helsinki University of Technology, Finland, 2005; Book online http://users.abo.fi/rzevenho/gasbook.html.

77. Gaser, U.; Tadular, E. L. United States Patent , 2009.

78. FLSmidth A/S. HOTDISC Combustion Device. 2011. Available at www.flsmidth.com (accessed 20/05/2014).

79. KHD Humboldt Wedag Burning Tehcnology: Pyroclon ${ }^{\circledR}$ calciner, KHD combustion chamber. 2012. Brochure available at www.khd.com (accessed 20/05/2014).

80. ThyssenKrup industrial solutions Special PREPOL calcining systems for different requirement profiles. 2014. Available at http://www.thyssenkrupp-industrial-solutions.com/ (accessed 20/05/2014).

81. Wirthwein, R.; Scharf, K. F.; Scur, P.; Drebelhoff, S. ZKG International 2002, 55, 61-69.

82. Saito, I.; Sakae, K.; Origi, T.; Ueda, Y. World Cement 1987, 18, 264-259. 
83. Kawasaki Heavy industries CKK at Work in China. Scope -Kawasaki Heavy industries quarterly newsletter. No. 96. 2013, Available at https://www.khi.co.jp.

84. Hass, J.; Agostini, A.; Martens, C.; Carrea, E.; van de Kamp, W. L. The combustion of pulverized coal and alternative fuels in cement kilns. Results on the CEMFLAME-3 experiments. International Flame Research Foundation (IFRF), IFRF doc no F97/y/4 1999.

85. Emberger, E.; Hoenig, V. Cement International 2011, 9, 84-60.

86. Arslan, E.; Cirucci, J.; Farmer, L.; Listemann, M.; Shah, J. International Cement Review 2013.

87. Leger, C. B.; Friday, J. G. IEEE-IAS/PCA 2001 Cem. Ind. Tech. Co. 2001, 271-277.

88. Ehrenberg, C.; Meissner, T. VDZ Congress 2009 on Process Technology of Cement Manufacturing 2009.

89. Streit, N. A modular Calciner Concept- The Right Solution for any Kind of Fuel. Presented at the ECRA Seminar: Experience with Precalciners, Kilns, Bernburg Novemeber, 2004.

90. Jensen, L.; Christensen, N.; Larsen, M. Denmark Patent WO 20210/032149, 2010.

91. Sprung, S.; Kirchner, G.; Rechenberg, W. ZKG Bauverlag GMBH/Maclean Hunter, Wiesbaden, Germany 1984, 37, 513-518.

92. Sprung, S.; Rechenberg, W. ZKG Bauverlag GMBH/Maclean Hunter Wiesbaden, Germany 1978, 31, 327-329.

93. Cenni, R.; Frandsen, F.; Gerhardt, T.; Spliethoff, H.; Hein, K. R. G. Waste Manage. 1998, $18,433-444$.

94. Paone, P. 2008 IEEE Cem. Ind. Tech. Co. 2008, 48-58.

95. Zheng, Y.; Jensen, A. D.; Windelin, C.; Jensen, F. Prog. Energy Comb. Sci. 2012, 38, 599629.

96. Zheng, Y.; Jensen, A. D.; Windelin, C.; Jensen, F. Fuel 2012, 93, 649-657.

97. Jawed, I.; Skalny, J. Cem. Concr. Res. 1977, 7, 719-729.

98. Sturz, A.; Itoh, M.; Smith, S. Proc Ocean Drill Prog Sci Results, 1998, Vol. 158.

99. Sengeløv, L. W. $\mathrm{HCl}$ emissions from modern cement production processes equipped with a by-pass, Master Thesis, Technical University of Denmark, 2012.

100. Zevenhoven, R.; Yrjas, P.; Hupa, M. 15th Proc. Int. Conf. Fluid. Bed Combust. 1999, 10001018.

101. Larsen, M.; Schultz, L.; Glarborg, P.; Skaarup-Jensen, L.; Dam-Johansen, K.; Frandsen, F.; Henriksen, U. Fuel 2006, 85, 1335-1345. 
102. Chinyama, M. P. M. Alternative Fuels in Cement Manufacturing; InTech, 2011. ISNB:978953-307-372-9.

103. Glasser, F. P. In Advances in Cement Clinkering; Bhatty, J. I., Miller, F. M. and Kosmathka, S. K., Eds.; Innovations in Portland Cement Manufacturing; Portland Cement Association (PCA): Illinois, USA, 2011.

104. Klotz, B. 1997 IEEE/PCA Cem. Ind. Tech. Co. XXXIX 1997, 255-280.

105. Hu, G. L.; Dam-Johansen, K.; Stig, W.; Hansen, J. P. Prog. Energy Combust. Sci. 2006, 32, 295-314.

106. Nielsen, P. B.; Jepsen, O. L. IEEE Cem. Ind. Tech. Co. XXXII 1990, 255-276.

107. Bech, C.; Gundtoft, L. EEE/PCA Cem. Ind. Tech. Co. XI 1998, 141-154.

108. Salmento, J. S.; Shenk, R. E. IEEE-IAS/PCA 2004 Cem. Ind. Tech. Co. 2004, 333-343.

109. Dam-Johansen, K.; Østergaard, K. Chem. Eng. Sci. 1991, 46, 827-837.

110. Hansen, P. F. B.; Dam-Johansen, K.; Bank, L. H.; Østergaard, K. 11th Proc. Int. Conf. Fluid. Bed Combust., Montreal, Canada 1991, 1.

111. Anthony, E. J.; Granatstein, D. L. Prog. Energy Combust. Sci. 2001, 27, 215-236.

112. Moss, G. 2nd Proc. Int. Conf. Fluid. Bed Combust. 1970, II-6, 1-7.

113. Burdett, N. A. Institute of Energy, London, Fluidized Combustion: Systems and Applications 1980, p. V1-1-V1-7.

114. Lin, W. Interactions between SO2 and NOx emissions in fluidized bed combustion of coal. $\mathrm{PhD}$ thesis, Technical University of Delft, The Netherlands, 1981. ISBN: 978-87-92481-665 .

115. Dam-Johansen, K.; Østergaard, K. Chem. Eng. Sci. 1991, 46, 855-859.

116. Hansen, P. F. B.; Johansen, K. D.; Østergaard, K. Chem. Eng. Sci. 1993, 48, 1325-1341.

117. Hu, G.; Dam-Johansen, K.; Wedel, S.; Hansen, J. P. Prog. Energy Combust. Sci. 2006, 32, 386-407.

118. Allen, D.; Hayhurst, A. N. J. Chem. Soc. Faraday Trans. 1996, 92, 1239-1242.

119. Qin, Z. J. Therm. Anal. 1995, 45, 211-219.

120. Choi, G. S.; Glasser, F. P. Cem. Concr. Res. 1988, 18, 367-374.

121. Lea, F. M.; Parker, T. W. Philos. Trans. A Math. Phys. Sci. 1935, 234, 1-U6.

122. De la Torre, A. G.; Morsli, K.; Zahir, M.; Aranda, M. A. G. J. Appl. Crystal. 2007, 40, 9991007. 
123. Mortensen, A. H.; Hintsteiner, E. A.; Rosholm, P. ZKG International 1998, 51, 84.

124. Bhatty, J. I. Role of Minor Elements in Cement Manufacture and Use; Research and Development Bulletin RD109T. Portland Cement Association, USA, 1995. ISNB: 0-89312$131-2$.

125. Hansen, J. P. SO2 emissions from cement production. PhD thesis, Technical University of Denmark, Denmark, 2003. ISBN: 87-90142-96-9.

126. Newkirk, T. F. Journal of Research of the National Bureau of Standards 1951, Research paper 2261.

127. Plang-ngern, S.; Rattanussorn, M. The Effect of Sulfur to Alkali Ratio on Clinker Properties. The Siam Research and Development Co., Ltd, Bangsue, Bangkok, Thailand 2003.

128. Whitehopleman Sulphur-to-alkali ratio Home Cement Industry Expertise. Available at http://whitehopleman.com/node/300. (Accessed in 26/04/2013).

129. Rahman, H.; Krapkat, T. Discussion about "Ideally the value alkali to sulphate ratio should be as close to 1 as possible, i.e. the alkali and sulphate should be in molar balance" in Cement Industry Experts group in www.linkedin.com, 2012. (Accessed in 10/03/2013).

130. Cemnet. Technical cement forum: Effect of reducing raw meal SO3 in clinker alkali. 2012. Available at http://cemnet.com (Accessed in 26/4/2013).

131. Fortsch, D. S.; Smidth, F. L. IEEE-IAS/PCA 2004 Cem Ind Tech Co, 2004, 103-109.

132. Cemnet. Technical Cement Forum: Ak1/ SO3 ratio. 2004. Available at http://cemnet.com (Accessed in 26/4/2013).

133. Nielsen, A. R.; Larsen, M. B.; Glarborg, P.; Dam-Johansen, K. Energy Fuels 2011, 25, 2917-2926.

134. Goldmann, W.; Kreft, W.; Schütte, R. World Cement Technology 1981, 12, 424.

135. Steuch, H. E.; Johansen, V. Sulfur dioxide emission from cement kilns. Rock Product International Seminar, USA, December 1990.

136. Christensens, N. H.; Johansen, V. Role of liquid phase and mineralizers. Conference Cement Production and Use 1979.

137. Rowe, J. J.; Morey, G. W.; Zen, C. S. Geol. Surv. Prof. Pap. (U.S.), 1972, No 741, 1-37.

138. Twomey, C.; Birkinshaw, C.; Breen, S. J Chem. Tech. and Biotech. 2004, 79, 486-490.

139. Pollitt, H. W. W.; Brown, A. W. Proceedings of the 5th International Symposium on the Chemistry of Cement 1969, 1, 322-333.

140. Uda, S.; Asakura, E.; Nagashima, M.. J. Am. Ceram. Soc. 1998, 81, 725-729. 
141. Ghosh, S. N. Cement and concrete science and technology, Vol 1,Part, 1; New Delhi, 1991;

142. Klemm, W. A.; Jawed, I.; Holub, K. J. Cem. Concr. Res. 1979, 9, 489-496.

143. Norbom, H. R. Proceedings of the IEEE Cem Ind Tech Co, Miami, Florida, U.S.A. 1973,

144. Johansen, J. M.; Aho, M.; Paakkinen, K.; Taipale, R.; Egsgaard, H.; Jakobsen, J. G.; Frandsen, F. J.; Glarborg, P. Proc. Comb. Inst. 2013, 34, 2363-2372.

145. Partanen, J. Chemistry of $\mathrm{HCl}$ and limestone in fluidized bed combustion, $\mathrm{PhD}$ thesis, Åbo Akademi, Finland, 2004. ISBN: 952-12-1287-X.

146. Saleh, S. B.; Flensborg, J. P.; Shoulaifar, T. K.; Sarossy, Z.; Hansen, B. B.; Egsgaard, H.; DeMartini, N.; Jensen, P. A.; Glarborg, P.; Dam-Johansen, K. Energy Fuels 2014, 28, 3738 3746.

147. Jøns, E.; Hundebol, S.; Clausen, K. IEEE Cem Ind Tech Co 2008, 178-192.

148. Partanen, J.; Backman, P.; Backman, R.; Hupa, M. Fuel 2005, 84, 1664-1673.

149. Partanen, J.; Backman, P.; Backman, R.; Hupa, M. Fuel 2005, 84, 1674-1684.

150. Partanen, J.; Backman, P.; Backman, R.; Hupa, M. Fuel 2005, 84, 1685-1694.

151. Jøns, E. S.; Østergaard, M. J. IEEE-IAS/PCA Cem Ind Tech Co, Vancouver, British Columbia, Canada, 2001, 343-359.

152. Dalton, J. L.; Gardner, K. H.; Seager, T. P.; Weimer, M. L.; Spear, J. C. M.; Magee, B. J. Resources Conservation and Recycling 2004, 41, 227-241.

153. Bucchi, R.. World Cement Technology 1981, 210-231.

154. Vassilev, S. V.; Vassileva, C. G. Fuel 2009, 88, 235-245.

155. Jawed, I.; Skalny, J. Cem. Concr. Res. 1978, 8, 37-52.

156. Skalny, J. P.; Klemm, W. A. Conference on Alkali- Aggregate Reaction in Concrete 1981, Cape Town, South Africa, 1-7.

157. Midgley, H. G. Clays Minerals 1984, 19, 857-864.

158. Farag, L. M.; Kamel, H. M. Zement-Kalk-Gips 1994, 47, 586-590.

159. ASTM Designation:C150-70 Stabndard Specificatioin for Portland Cement. The Americal Society for Tes and Materials, Philadelphia, USA. .

160. British ecological survey Mineral profile. Cement raw materials. 2005. Available at www.britishecologiscalsociety.org

161. Smaoui, N.; Berube, M. A.; Fournier, B.; Bissonnette, B.; Durand, B. Cem. Concr. Res. 2005, 35, 203-212. 
162. Saint-Jean, S. J.; Jons, E.; Lundgaard, N.; Hansen, S. Cem. Concr. Res. 2005, 35, 431-437.

163. Nievoll, J.; Jörg, S.; Dösinger, K.; Corpus, J. World Cement 2009, 78-83.

164. Recio Dominguez, I.; Gomez-Millan, J.; Alvarez, M.; De Aza, S.; Contreras, L.; De Aza, A. H. Journal of the European Ceramic Society 2010, 30, 1879-1885.

165. Wolfson, R. G.; Kobes, W.; Fine, M. E. J. Appl. Phys. 1966, 37, 704-\&.

166. Kurdowski, W; Sobon, M. Journal of Thermal Analysis and Calorimetry 1999, 55, 10211029.

167. Saint-Jean, S. J. Crystallographic studies of Chlorellestadite, an intermediate compound in the production of Portland cement, Material Chemistry, Lund Institute of Technology, Lund, Sweden, 2003.

168. Enders, M. Cement International 2011, 9, 38-53.

169. Peray, K. E.; Waddell, J. J. The rotary cement kiln; Chemical Publishing Co.New York, 1972. ISBN: 978-08-20603-67-4.

170. Hamilton, F. C. International Cement review. December 1997, 54-62.

171. Katsioti, M. World Cement Research and Development 1996, 66-68.

172. Clark, M. International Cement Review 2011, 60-63.

173. Palmer, G. World cement 1990, 538-543.

174. Rowe, J. J.; Morey, G. W.; Hansen, I. D. Journal of Inorganic and Nuclear Chemistry 1965, $27,53-58$

175. Herfort, D.; Moir, G. K.; Johansen, V.; Sorrentino, F.; Arceo, H. B.Adv Cem Res 2010, 22, 187-194.

176. Lai, G. Y. High Temperature Corrosion of Engineering Alloys; ASM International, 1990. ISBN: 978-0871704115.

177. Kotter, E.; Bartha, P. Zem-Kalk-Gips 1987, 40, 157-161.

178. Karlsson, A. Personal communication: acceptable level corrosion rate in kiln shell. November 22, 2013.

179. Holtemann, J. Korrosion indvendigt i ovnrør. Internal FLSmidth memo (in Danish). 1995.

180. Lechtenberg, D.; Diller, H. Alternative fuels and raw materials handbook for the cement and lime industry. MVW Lechtenberg \& Partner: Düsseldorf, Germany, 2012. ISBN: 978-37640-0550-4.

181. Gineys, N.; Aouad, G.; Sorrentino, F.; Damidot, D. Cem. Concr. Res. 2011, 41, 1177-1184. 
182. Conesa, J. A.; Galvez, A.; Mateos, F.; Martin-Gullon, I.; Font, R. J. Hazard. Mater. 2008, $158,585-592$.

183. Klauss, J. ZKG International 2000, 53, 132-144.

184. Trezza, M. A.; Scian, A. N. Cem. Concr. Res. 2000, 30, 137-144.

185. Pipilikaki, P.; Katsioti, M.; Papageorgiou, D.; Fragoulis, D.; Chaniotakis, E. Cem. Concr. Compos. 2005, 27, 843-847.

186. Trezza, M. A.; Scian, A. N. Cem. Concr. Res. 2005, 35, 438-444.

187. Sylla, H. M. Einfluss reduzierenden Brennens auf die Eigenschaften des Zementklinkers (in German). ZKG 1981, 12.

188. Schaefer, T.; Mathiesen, C. Analyzer 1996, 5173.

189. Kuusik, R.; Sikkonen, P.; Niinistö, L. T. Journal of Thermal Analysis 1985, 30, 187-193.

190. Oh, J. S.; Wheelock, T. D. Ind Eng Chem Res 1990, 29, 544-550.

191. Okumura, S.; Mihara, N.; Kamiya, K.; Ozawa, S.; Onyango, M.; Kojima, Y.; Matsuda, H.. Ind Eng Chem Res 2003, 42, 6046-6052.

192. Tian, H.; Guo, Q. Ind Eng Chem Res 2009, 48, 5624-5632.

193. Tian, H.; Guo, Q.; Chang, J. Energy Fuels 2008, 22, 3915-3921.

194. Xiao, R.; Song, Q. Combust. Flame 2011, 158, 2524-2539.

195. Zheng, M.; Shen, L.; Feng, X.; Xiao, J. Ind Eng Chem Res 2011, 50, 5414-5427.

196. Kim, B.; Sohn, H. Y. Ind Eng Chem Res 2002, 41, 3092-3096.

197. Shen, L.; Zheng, M.; Xiao, J.; Xiao, R. Combust. Flame 2008, 154, 489-506.

198. Song, Q.; Xiao, R.; Deng, Z.; Zhang, H.; Shen, L.; Xiao, J.; Zhang, M. Energy Conv. Manag. 2008, 49, 3178-3187.

199. Song, Q.; Xiao, R.; Deng, Z.; Shen, L.; Zhang, M. Korean J. Chem. Eng. 2009, 26, 592602.

200. Ostroff, A. G.; Sanderson, R. T. J. Inorg. Nucl. Chem. 1959, 9, 45-50.

201. Nielsen, A. R.; Larsen, M. B.; Glarborg, P.; Dam-Johansen, K. Energy Fuels 2011, 25, 3917-3924.

202. Cortada Mut, M.; Nørskov, L. K.; Glarborg, P.; Dam-Johansen, K. Energy Fuels 2015, 29, $2729-2737$.

203. Tsoumeleas, C. I.; Katsioti, M.; Georgali, B.; Marinos, J. World Cement 2001, 67-69. 
204. Scheffknecht, G.; Al-Makhadmeh, L.; Schnell, U.; Maier, J. Int. J. Greenh. Gas Control 2011, 5, Supplement 1, S16-S35.

205. Fleig, D.; Andersson, K.; Normann, F.; Johnsson, F. Ind Eng Chem Res 2011, 50, 85058514.

206. Wall, T.; Liu, Y.; Spero, C.; Elliott, L.; Khare, S.; Rathnam, R.; Zeenathal, F.; Moghtaderi, B.; Buhre, B.; Sheng, C.; Gupta, R.; Yamada, T.; Makino, K.; Yu, J. Chem. Eng. Res. Des. 2009, 87, 1003-1016.

207. Laux, S.; Mocsari, J. Oxygen-enhanced combustion of alternative fuels. 2011. Available at http://www.cemfuels.com (accessed 20/4/2015).

208. Pedersen, A. J.; van Lith, S. C.; Frandsen, F. J.; Steinsen, S. D.; Holgersen, L. B. Fuel Process Technol 2010, 91, 1062-1072.

209. Sutou, K.; Harada, H.; Ueno, N. IEEE/PCA Cem Ind Tech Co, Virginia 1999, 179-193. 